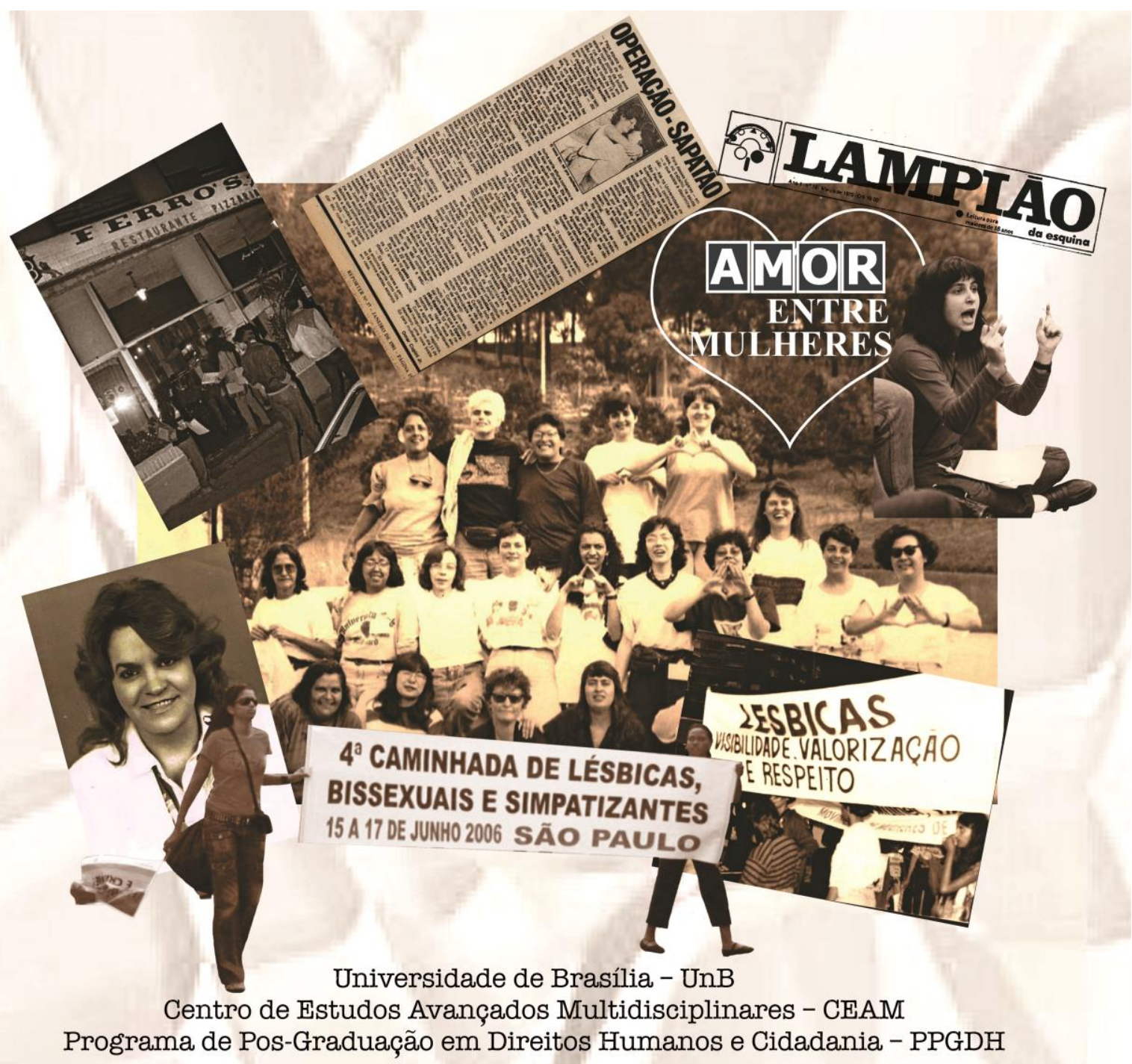

\title{
Vozes Lésbicas no Brasil A Busca e os Sentidos da Cidadania LGBT
}

\section{Irina Karla Bacci}

Brasília, março de 2016

Universidade de Brasília - UnB 


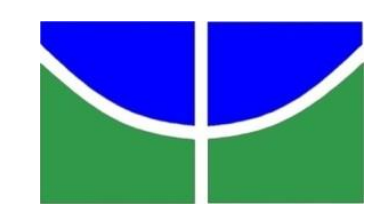

Universidade de Brasília - UnB

Centro de Estudos Avançados Multidisciplinares - CEAM

Programa de Pós-Graduação em Direitos Humanos e Cidadania - PPGDH

VOZES LÉSBICAS NO BRASIL

A BUSCA E OS SENTIDOS DA CIDADANIA LGBT

Irina Karla Bacci

Brasília, março de 2016 


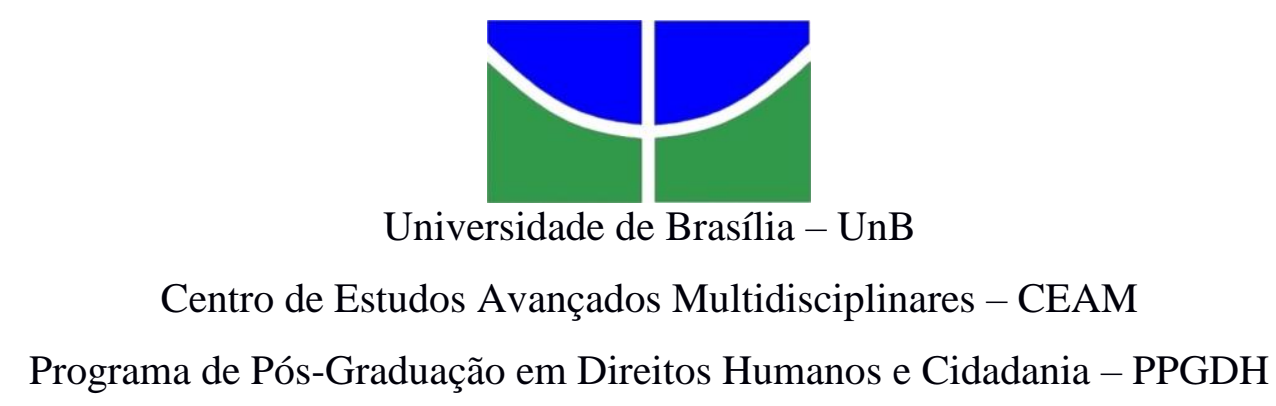

\section{VOZES LÉSBICAS NO BRASIL}

A BUSCA E OS SENTIDOS DA CIDADANIA LGBT

Irina Karla Bacci

Dissertação apresentada ao Programa de PósGraduação em Direitos Humanos e Cidadania do Centro de Estudos Avançados Multidisciplinares da Universidade de Brasília, como requisito parcial para a obtenção do título de Mestrado em Direitos Humanos e Cidadania.

Orientadora: Prof. Dr ${ }^{\mathrm{a}}$. Rita Laura Segato 
Ficha catalográfica elaborada automaticamente, com os dados fornecidos pelo(a) autor(a)

Bacci, Irina Karla

BB117v Vozes Lésbicas no Brasil: A busca e os sentidos da cidadania LGBT / Irina Karla Bacci; orientador Rita Laura Segato. -- Brasília, 2016. $117 \mathrm{p}$.

Dissertação (Mestrado - Mestrado em Direitos Humanos e Cidadania) -- Universidade de Brasília, 2016 .

1. Lésbicas. 2. LGBT. 3. Cidadania. 4. Lesbianidade. 5. Reconhecimento. I. Segato, Rita Laura, orient. II. Título. 


\section{Irina Karla Bacci}

Vozes lésbicas no Brasil: a busca e os sentidos da cidadania LGBT

Dissertação apresentada ao Programa de Pós-Graduação em Direitos Humanos e Cidadania, da Universidade de Brasília - UnB, como requisito parcial à obtenção do título de Mestre em Direitos Humanos e Cidadania.

Orientadora: Prof. Dr ${ }^{\mathrm{a}}$. Rita Laura Segato

Banca examinadora:

Prof $^{a}$. Dr ${ }^{a}$. Rita Laura Segato (presidente) Universidade de Brasília - PPGDH/UnB

Prof. Dr. Wanderson Flor do Nascimento (membro externo) Universidade de Brasília FIL/UnB

Prof $^{\mathrm{a}}$. Dr ${ }^{\mathrm{a}}$. Vanessa Maria de Castro (membro interno) Universidade de Brasília PPGDH/UnB

Aprovada em 10 de março de 2016 
"Se nós, lésbicas e homossexuais, continuarmos a falar de nós próprias (os) e a conceber-nos como mulheres e como homens, estamos a ser instrumentais na manutenção da heterossexualidade." Monique Wittig 


\section{AGRADECIMENTOS}

A realização e o ingresso no mestrado em Direitos Humanos e Cidadania, assim como para a escrita desta dissertação, foram encorajados pela minha companheira, namorada, amiga e parceira Cecília Nunes Froemming. Minha família, meu amor, meu chão, minha companheira de vida e militância, minha professora e coorientadora, você foi crucial para a conclusão desta tarefa. Obrigada pelo amor e pela compreensão, a ti dedico esta conquista.

Agradeço às minhas companheiras de militância, amigas e parceiras, que me acolheram e, ainda, gentilmente se permitiram dar voz a este trabalho: a Marisa, Heliana e Yáskara o meu muito obrigada.

Às demais companheiras Carmem, Verônica, Miriam, Rosely, Neusa, Beth, Eide e Cassandra. As citadas Lurdinha, Maria Angélica Lemos, Lurdinha Rodrigues, Jane Pantel, Zora Yonara e Yone.

À professora Dr. ${ }^{a}$ Rita Laura Segato, por aceitar ser minha orientadora, pela dedicação e estudos ao movimento de mulheres, pela sabedoria, ensinamentos e, principalmente, pela acolhida e solidariedade feminista. Aos professores e professoras do PPGDH, em especial, à professora Dr. ${ }^{a}$ Vanessa Maria de Castro pelos muitos ensinamentos, pela compreensão, dedicação e por aceitar estar na minha banca, a qual estendo o agradecimento ao professor Dr. Wanderson Flor do Nascimento.

Aos meus colegas, amigas e amigos da segunda turma de mestrado, muito obrigada pela acolhida, pelas contribuições diárias durante esses anos de convivência e pela amizade que levarei para a vida. Bruna, Diego, Fred, Erika, Eliane, Fábio, Julia, Larissa, Priscila, Raul, Vanessa e Vitor foi muita sorte tê-los nesta trajetória e em minha turma, seguimos lutando!

À minha família, meu pai, minha mãe, que sei que deve estar demasiadamente orgulhosa (in memoriam), meus irmãos, minha irmã Dani e Tata (in memoriam), meus sobrinhos e minhas sobrinhas, em especial a Gabi e a Bia, por quem sigo lutando para deixar um mundo mais gentil, e a mais nova, recente e novo amor da minha vida, Nina Simone Odara.

Por fim, aos meus guias espirituais, aos invisíveis, que muito ajudaram na inspiração e na proteção, e ao meu orixá, meu pai Xangô, a quem dei minha cabeça, minha segurança e meu caminho. 


\section{Resumo}

Este trabalho tem por objetivo dar voz a diversas mulheres lésbicas que, ao longo de sua trajetória de vida, política e pessoal, contribuíram na busca e nos sentidos da cidadania LGBT no Brasil. Sob a perspectiva de ausência de marco legal que ordene normas jurídicas de cidadania, compreender as histórias de vida, suas trajetórias e os caminhos percorridos deu sentido às vidas retratadas neste trabalho. A ação pelo reconhecimento da lesbianidade é luta central das mulheres lésbicas e foi abordada como eixo de suas histórias na busca de uma cidadania que é muito mais um sentir do que um fato jurídico.

Palavras-chave: Lésbicas. LGBT. Cidadania. Lesbianidade. Reconhecimento. 


\begin{abstract}
This paper aims to give voice to many lesbian women that throughout its history, politics and personal life, helped in the search and senses LGBT citizenship in Brazil. From the perspective of lack of legal framework order legal rules of citizenship, understand the life stories, their trajectories and paths traversed gave the lives portrayed in this work. The fight for the recognition of lesbianism is central struggle lesbian woman that was approached as the axis of their stories in the search of a citizenship that much more a feeling than a legal fact.
\end{abstract}

Keywords: Lesbian. LGBT. Citizenship. Lesbianism. Recognition. 


\section{SUMÁRIO}

INTRODUÇÃ

Capítulo 1 ..................................................................................................................................................... 15

DIREITOS HUMANOS, CIDADANIA E MARCOS NORMATIVOS ............................... 15

1.2 Processos de Construção Histórica do Conceito de Cidadania ................................................... 17

1.2 A Cidadania na Constituiçãa Federal de 1988................................................................................... 24

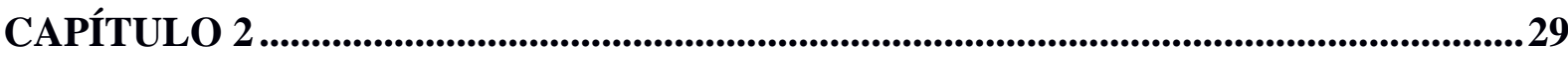

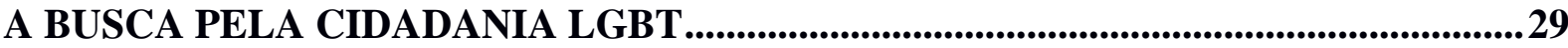

2.1 Luta e Organização Política do Movimento LGBT no Brasil..................................................... 31

2.2 Marcos das Políticas para Mulheres Lésbicas e Bissexuais no Brasil...................................... 36

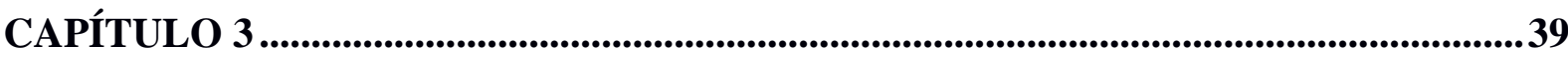

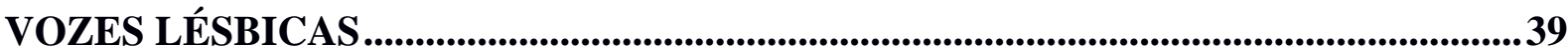

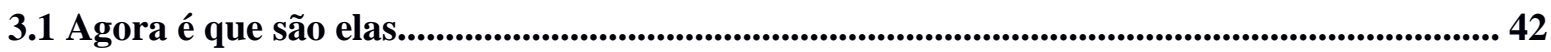

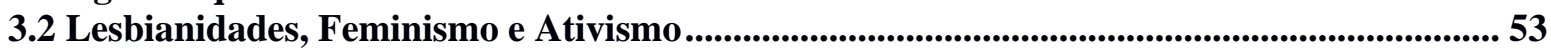

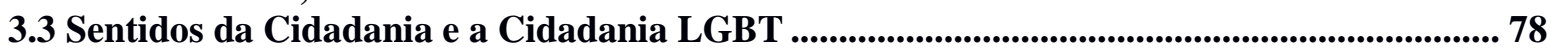

CONSIDERAÇÕES FINAIS..................................................................................................82

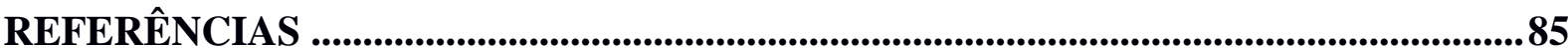

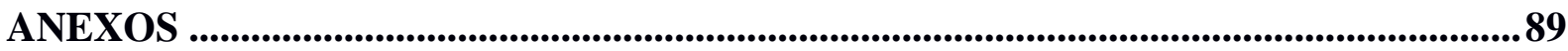

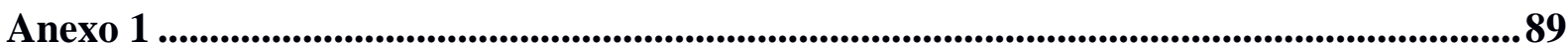

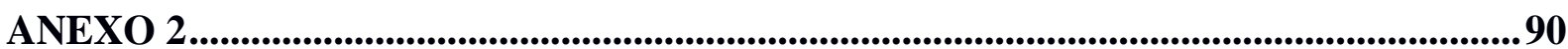

MANIFESTO DO COLETIVO DE MULHERES FEMINISTAS DA ABGLT ...............90

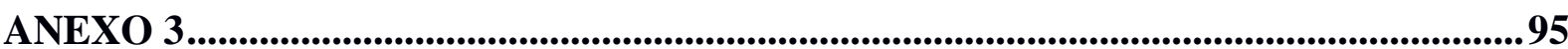

NOTA SOBRE A $19^{\circ}$ SESSÃO DO CONSELHO DE DIREITOS HUMANOS DA ONU

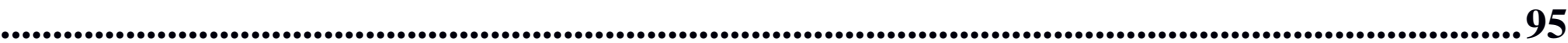

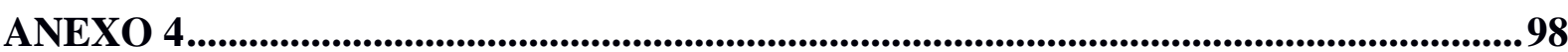

DISCURSO REALIZADO NO PAINEL DISCRIMINAÇÃO E VIOLÊNCIA

BASEADO EM ORIENTAÇÃO SEXUAL DA $19^{\circ}$ SESSÃ̃O DO CONSELHO DE

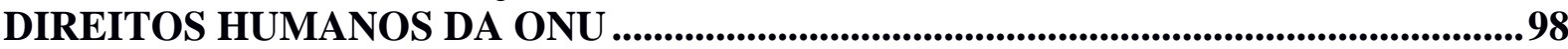

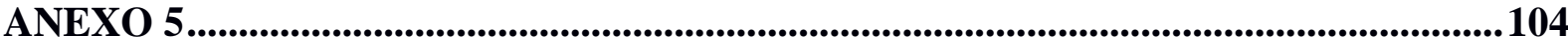

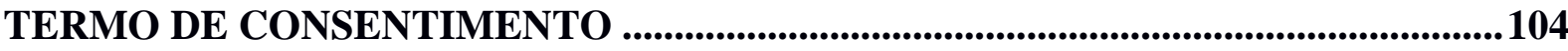

ANEXO 6....................................................................................................................................... 105

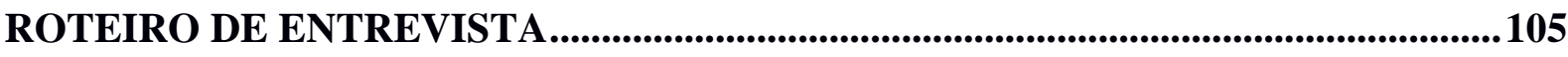

ANEXO 7..................................................................................................................................................... 109

FOTOS 


\section{INTRODUÇÃO}

Ao decidir escrever sobre as trajetórias percorridas pelo movimento LGBT na conquista de direitos, optei fazê-lo ouvindo as vozes de ativistas lésbicas. Lésbica, ativista e feminista, minha luta contribuiu para essa trajetória e muitas das descritas neste trabalho contribuíram para minha vida pessoal e militante.

Nos atuais dias, o movimento LGBT ganhou espaço na mídia, nas instituições políticas, governamentais e sociais, ganhou as ruas, ganhou, inclusive, uma parte da opinião pública, mas ainda não goza de plenos direitos e, fundamentalmente, do direito de ir e vir sem ser notado e sem sofrer violência.

Ao passo que parte da opinião pública passa a dar publicidade às demandas legítimas de cidadãos e cidadãs LGBT, outra parte da sociedade que tem grande representatividade no parlamento e na mídia se organiza e enfrenta os poucos avanços obtidos, impõe retrocessos e fomenta disputas inexistentes, hierarquizando cidadanias entre indivíduos e famílias.

Ao entrevistar as ativistas, de certa forma, ouvi um pouco de minha história, dos caminhos que igualmente percorri na militância LGBT e, por algumas, ainda fui citada pelas contribuições ao movimento, pelo carinho e solidariedade delas.

Identifiquei-me com suas dores, seus amores, mas, principalmente, com as histórias que as tornaram lideranças, pela persistência em se fazer ouvir, em não se calar e em existir.

Não saberia ao certo dizer quando se iniciou em minha vida a militância LGBT, mas me lembro de frequentar os saraus organizados por um grupo de lésbicas (2001), que logo passou a se chamar Umas e Outras, reunindo-se em uma livraria na região dos jardins em São Paulo e também em parques.

A experiência com o grupo não foi muito longa, pois me mudei para o interior de São Paulo. Ainda motivada pelo grupo que acabara de conhecer em São Paulo e pela necessidade de encontrar pares numa cidade em que não conhecia ninguém, busquei na internet um grupo de pessoas que se reuniam com o mesmo objetivo de convivência entre pares e, lá, conheci o grupo Famílias Alternativas.

Famílias Alternativas era mais conhecida como FALT, e suas fundadoras (2002), Maria Rita Lemos e Fúlvia Margot, organizavam uma lista de discussão na rede que possibilitava a aproximação de pessoas LGBT, em grande parte casais, casais com filhos, pais solteiros e, ainda, os que aspiravam ter filhos e filhas para troca de informações, partilhar histórias de vidas e, principalmente, tirar aquelas pessoas do isolamento. 
As fundadoras moravam em Limeira, interior de São Paulo, a 20 minutos de onde eu morava e, além de frequentar a lista, passei a frequentar a casa delas e, logo, com o apoio da maioria do grupo, criamos um encontro presencial para que todas e todos pudessem se conhecer. Mas a necessidade ia além - não somente tinham desejo de se conhecer, como muitos tinham desejo de mudar alguma coisa, de saírem do isolamento, de saírem do anonimato, de terem seus direitos reconhecidos, suas famílias igualmente reconhecidas e aos seus filhos um futuro diferente.

Nessa perspectiva, o grupo passou a organizar participação na Parada do Orgulho LGBT de São Paulo, a pedir participação em encontros do movimento no estado, e essa necessidade militante do grupo fez com que parte dele fundasse o Inova, que se tornou a primeira associação brasileira de famílias GLBTT, então denominação usada pelo movimento à época, cuja fundação se deu em 2005.

Recordo-me que foi no II Seminário Nacional GLBT, após participar da Parada do Orgulho LGBT do Rio de Janeiro, que conheci ativistas importantes ao movimento e para minha formação política. Conheci nesse dia Marisa Fernandes, que me convidou a integrar o Coletivo de Feministas Lésbicas; Yone Lindgren, para anos mais tarde atuarmos juntas nas redes nacionais ABL e ABGLT; Toni Reis, que me lembrou de sua história conhecida nacionalmente, sua luta pela permanência de seu companheiro, David Harrad, o qual foi expulso do país pela Polícia Federal e, sua mãe, em gesto de amor pelo filho, casou-se com ele para que permanecesse no país; Tommaso Besozzi, um italiano que teve de deixar o Brasil em 2002, e seu companheiro Edmilson Medeiros, dos quais me aproximei imediatamente pelas afinidades e muitas parcerias que tivemos; a deputada Maria do Rosário; e deputada à época, e hoje senadora Fátima Bezerra; e a ex-deputada federal Iara Bernardi ${ }^{1}$.

Nessa época, eu já era conhecida no movimento pela participação no Seminário Nacional GLBT, em 2005, que ocorria na Câmara dos Deputados, e na Audiência Pública realizada pela Comissão Especial da Lei Nacional da Adoção na Câmara dos Deputados, por ocasião do PL 1.756/2003, realizada também em $2005^{2}$ a convite da presidente da Comissão, deputada Maria do Rosário Nunes.

Após as experiências citadas não me lembro de nenhum dia em minha vida em que eu

1 Disponível em: <http://www.clam.org.br/publique/cgi/cgilua.exe/sys/start.htm?infoid=339\&sid=3>. Acesso em: 16 fev. 2016, às $19 \mathrm{~h} 45$.

2 Disponível em: <http://www.camara.leg.br/internet/sitaqweb/TextoHTML.asp?etapa=11\&nuSessao=1701/05>. Acesso em: 16 fev. 2016, às 19 h03. 
não tenha sido ativista e militante, de nenhum dia ter desejado coisas diferentes e de não ter em meu cotidiano demandas ativistas das quais, desde que me percebi lésbica, não saberia identificar o que é pessoal e o que é ativismo.

De 2005 até hoje, meus dias foram cada vez mais cheios de atividades e tomados pela militância, passei por grupos, fóruns, conselhos, redes nacionais e representações internacionais.

Recordo-me de algumas passagens como se fosse hoje - quando da organização de diversos grupos pelo interior do estado de São Paulo na coordenação do Projeto Redes, e que trouxe à cena do movimento LGBT diversos ativistas que hoje se configuram como coordenadores de políticas LGBT em seus municípios, além de grupos no interior, que antes não existiam e que hoje organizam paradas e atividades de visibilidade para a população LGBT; da eleição para a Presidência do Conselho Municipal LGBT de São Paulo; da participação na organização da I Conferência Nacional LGBT, que teve como ponto máximo a participação do então presidente Lula, ovacionado por mais de mil participantes que sentiram naquele ato o reconhecimento do Estado brasileiro em sua cidadania LGBT; da eleição para a primeira mesa diretora do Conselho Nacional LGBT, posteriormente vicepresidente e presidente; e, por fim, na participação no painel ${ }^{3}$ "Discriminação e Violência baseada em Orientação Sexual e Identidade de Gênero", ocorrido na $19^{a}$ Sessão do Conselho de Direitos Humanos da ONU, em 07 de março de 2012, a única ativista presente no painel quando diversos delegados da Organização pela Cooperação Islâmica (OIC), do grupo de países Árabes e do grupo de países Africanos, abandonaram o salão em protesto à realização do painel e à presença de ativistas LGBT.

Deixei para o fim falar da experiência ativista e profissional que tive quando coordenei o Centro de Referência da Diversidade (CRD), serviço de proteção especial de média complexidade administrado pelo Grupo Pela Vidda de São Paulo, um serviço conveniado com a Prefeitura. Essa experiência, que durou de 2009 a 2012, foi a mais reveladora em minha vida. Lá não só descobri a razão pela qual não é possível negligenciar nossa estada nesta vida sem luta, como também percebi que muito do que havia feito até então não se refletia na vida de muitos ainda não cidadãos e cidadãs LGBT.

A atuação militante descrita foi a motivação para o ingresso no Programa de PósGraduação em Direitos Humanos e Cidadania da Universidade de Brasília (UnB), e pesquisar

3 Disponível em: <http://ilga.org/pt-br/irina-bacci-painel-discrimina-o-e-viol-ncia-baseado-em-orienta-osexual-e-identidade-de-g-nero-do-conselho-de-direitos-humanos/>. Acesso em: 16 fev. 2016, às 20h30. A Sessão esta disponível no link. 
os caminhos percorridos durante esse período da minha vida era necessário para devolver tudo aquilo que aprendi e que me tornou quem sou hoje.

Nesse sentido, esta introdução abre a dissertação com relatos de minhas experiências militantes, minhas considerações iniciais ao trabalho, que demandaram as razões para mergulhar neste estudo, as justificativas, os objetivos e a apresentação da pesquisa em três capítulos.

Das aspirações iniciais, o presente trabalho tinha por objetivo dar voz às ativistas lésbicas, verificar os caminhos percorridos em suas trajetórias, que contribuíram para a busca e o sentido da cidadania LGBT no Brasil. Dos objetivos específicos, cada qual explorado em um capítulo desta dissertação, pretendi alcançar: $i$ ) compreender os principais contextos da história do movimento de lésbicas no Brasil e seus impactos na conformação do movimento nas suas sucessivas etapas; ii) apontar as diferentes posições dentro do movimento LGBT desde a sua fundação, suas aproximações e antagonismos, suas rupturas e subdivisões por seus atores mais influentes; iii) verificar os entraves sociais e políticos no reconhecimento da cidadania LGBT, por meio dos marcos históricos contado pelas ativistas; e $i v$ ) identificar os percursos percorridos pelo movimento social na construção da cidadania LGBT por meio das vozes de ativistas.

No capítulo 1, Direitos Humanos, Cidadania e Marcos Normativos, pretende-se contextualizar na história os marcos de direitos humanos vigentes no Brasil; uma breve introdução sobre a história da construção do movimento de lésbicas e as notas introdutórias dos caminhos que foram percorridos na perseguição da cidadania de LGBT no Brasil.

No capítulo 2, A Busca pela Cidadania LGBT no Brasil, são exploradas as lutas por direitos LGBT no Brasil, o reconhecimento das identidades, a luta e organização política do Movimento LGBT no Brasil, os marcos históricos na luta pelo direito ao casamento igualitário, o enfrentamento à violência, direitos à adoção e à herança e os marcos das políticas para mulheres lésbicas e bissexuais no Brasil.

Por fim, no capítulo 3, As Vozes Lésbicas no Brasil, por meio das ativistas entrevistadas, tem-se a apresentação metodológica, os contextos históricos, as rupturas, impactos e posições assumidas no movimento, que deram sentido à cidadania LGBT. 


\section{CAPÍTULO 1 \\ DIREITOS HUMANOS, CIDADANIA E MARCOS NORMATIVOS}

Este capítulo trata da contextualização histórica dos marcos de direitos humanos vigentes no Brasil para uma breve introdução sobre a história da construção do movimento de lésbicas. Trata-se de abrir as cortinas para refletirmos sobre quais caminhos foram percorridos na perseguição da cidadania de LGBT no Brasil. Ao observar esses caminhos, é inevitável a analogia com a conquista da democracia pela homologação da Constituição Federal de 1988 CF/1988, a qual afirma que cidadãs e cidadãos brasileiros são iguais em direitos e, consequentemente, que os seres humanos têm direito de serem igualmente respeitados pelo simples fato de sua humanidade, que nos remete à ideia central de luta dos direitos humanos.

Sem dúvida, seria temeroso afirmar que o ordenamento jurídico tenha alcançado uma definição rigorosa do conceito de direito humano (COMPARATO, 1997). Para Norberto Bobbio (1999), os direitos humanos não nascem todos juntos e de uma só vez, pensamento que está em consonância Hannah Arendt (1989), que afirma que os direitos humanos não são um dado, mas um construído, uma invenção humana em constante processo de construção e reconstrução (PIOVEZAN, 2005).

A Declaração Universal dos Direitos Humanos, promulgada pelas Nações Unidas em 10 de dezembro de 1948, introduziu uma concepção ampla de direitos humanos ao considerar todas as pessoas titulares de direitos, independentemente de sua condição social, sexo, credo político ou religioso, raça/etnia. Mesmo que a Declaração faça referência à igualdade de direitos entre homens e mulheres, direitos humanos nem sempre tratavam de violações aos direitos humanos das mulheres. As mulheres são invisibilizadas e foram excluídas dos direitos humanos por serem discriminadas historicamente.

Segundo Lindgren Alves (2005), a Conferência Mundial de Viena (1993) consagrou os direitos humanos como tema global, reafirmando, por consenso, a universalidade, a indivisibilidade e a onipresença. E foi somente nessa conferência que os direitos humanos das mulheres foram reconhecidos, o documento produzido ao final, a Declaração de Direitos Humanos de Viena, em seu parágrafo 18, afirma categoricamente que os direitos humanos das mulheres e das meninas são parte inalienável, integral e indivisível dos direitos humanos.

A Resolução no 32/130 da Assembleia Geral da Organização das Nações Unidas afirma que todos os direitos humanos, qualquer que seja o tipo a que pertençam, interrelacionam-se, são indivisíveis e interdependentes. Essa máxima de conceituação dos direitos 
humanos também é corroborada pela Declaração de Direitos Humanos de Viena, de 1993, especificamente no art. $5^{\circ}$, que afirma que "Todos os direitos humanos são universais, indivisíveis, interdependentes e inter-relacionados [...]".

A universalidade pressupõe que a condição de pessoa é o requisito único para a titularidade dos direitos humanos, independentemente de credo, raça, sexo, cor, nacionalidade e convicções. A indivisibilidade, por sua vez, afirma que os direitos humanos não admitem fracionamento: violado algum direito social, por exemplo, invariavelmente os direitos econômicos, culturais, civis e políticos também o serão. Ser inviolável compreende que os direitos não podem ser descumpridos por nenhuma pessoa ou autoridade; ao passo que a indisponibilidade preceitua que os direitos não podem ser renunciados, uma vez que não cabe ao particular dispor dos direitos conforme a própria vontade. Por fim, importante mencionar mais duas características: a imprescribilidade, de acordo com a qual os direitos não se perdem com o decurso do tempo, e a complementaridade por direitos humanos que devem ser interpretados em conjunto, não havendo hierarquia entre eles (ALVES, 2005; PIOVEZAN, 2005).

O debate sobre os fundamentos dos direitos humanos encontra-se intimamente relacionado com a própria eficácia dos mecanismos garantidores do sistema de proteção desses direitos, que nos leva a considerar uma diversidade de fatores, contextos e culturas que influenciam diretamente na construção dos direitos, no exercício da cidadania e, principalmente, sua eficácia nas mais diversas esferas.

Herrera Flores (2009) observa que, para um melhor entendimento dos direitos humanos, é preciso compreendê-los em sua multicomplexidade cultural, empírica, jurídica, científica, filosófica, política e econômica. Ainda defende que a compreensão dos direitos humanos está além das normas e do ordenamento jurídico, constitui-se como processos institucionais e sociais para a conquista daquilo que entende ser o único elemento ético e político universal: a dignidade humana. Podemos entender que o conceito de dignidade humana e a necessidade da garantia aos direitos humanos vêm também de um processo natural da evolução humana, como um desejo de mudança, uma busca constante de renovada ordem social.

Habermas (2010) oferece algumas razões jurídicas para mostrar que a "dignidade humana" não é unicamente uma expressão classificatória, como se se tratasse de um parâmetro de substituição vazio que agrupasse uma multiplicidade de diferentes fenômenos. Pelo contrário, ele sustenta em três pontos: $i$ ) que ela constitui a "fonte" moral da qual todos os direitos fundamentais derivam o seu sustento; $i$ ) a função catalizadora desempenhada pelo 
conceito de dignidade na construção dos direitos humanos, nos termos de uma história conceitual e a partir da moral racional e também na forma de direitos subjetivos; e iii) a origem dos direitos humanos na noção moral de dignidade humana pode dar conta da força política explosiva da utopia concreta, tanto contra a recusa generalizada dos direitos humanos quanto das tentativas mais recentes de cortar na raiz a sua força radical.

$\mathrm{O}$ autor reforça que o significado jurídico da dignidade humana não se esgota na função de ocultar diferenças mais profundas, mas sim pelo fato de que o conceito de "dignidade humana" também possa, quando necessário, facilitar sempre que for necessário estender os direitos humanos. Argumenta, ainda, que as condições históricas mutáveis simplesmente nos tornam conscientes de algo que já se encontrava inscrito desde o início nos direitos humanos: o substrato normativo da igual dignidade de cada ser humano que os direitos humanos unicamente precisam mais detalhadamente.

\subsection{Processos de Construção Histórica do Conceito de Cidadania}

A palavra cidadania vem do latim civitatem, que significa "cidade". Isso nos remete, concomitantemente, à expressão grega polis, “cidades-estados" da antiguidade. O filósofo Aristóteles, no seu Livro III da Política, responde quem é o cidadão, ou, ainda de forma direta, diz que é ele aquele que pode participar das magistraturas da cidade. No entanto, para compreender quem e qual pessoa devem ser chamadas de cidadão, ele descreve seis formas de regime: realeza, aristocracia, regime constitucional, tirania, oligarquia e democracia (BOTELHO; SCHWARCZ, 2012).

No entendimento de Aristóteles, cidadão é o indivíduo titular de direitos que participa de forma direta das decisões da cidade, mas também aquele que, sob a tutela de um regime, ainda que excluído, está de forma desviada do entendimento cidadão, mas dentro de sua compreensão. Nessa fase, cidadania se restringia à participação política de determinadas classes sociais. Cidadão era aquele homem que morava na cidade e participava de seus negócios. Os entendidos cidadãos (que não eram as mulheres, os escravos, os estrangeiros, entre outros), então, participavam das assembleias e, por isso, tinham o poder de resolver questões da cidade. O mesmo ocorria entre os romanos, via-se claramente a exclusão daqueles considerados não nobres e estrangeiros, que, portanto, não detinham direitos (BOTELHO; SCHWARCZ, 2012).

Contudo, com o advento das mudanças ocorridas no período da Idade Média, a preocupação política cedeu espaço às questões religiosas, e a ideia de cidadania foi colocada 
em segundo plano. A sociedade medieval se organizava de forma estamental, apresentando uma estrutura em que a posição social do indivíduo é determinada pelo seu nascimento, pela sua origem familiar, que determinava as categorias de nobreza, o clero e os camponeses, tendo as referidas classes, direitos e privilégios distintos.

Tal situação só se modificou com o surgimento dos Estados nacionais. Contudo, as mudanças sociais advindas das novas necessidades materiais aliadas ao fenômeno da cristianização passaram a exigir uma reformulação do conceito de cidadania, que já não atendida às demandas, surgindo, então, a ideia de igualdade. Nos anos seguintes, vivenciamos um longo período de transição e de transformações políticas, econômicas, artísticas, o que contribuiu também para o despertar do ideal de liberdade.

A ideia de cidadania adquire fundamentos filosóficos modernos, especialmente na tradição contratualista e como constatado nas obras dos filósofos como Locke (1632-1704) e Rousseau (1712-78). É com eles que a ideia de um contrato firmado entre cidadãos e o Estado ganha importância. Mas essa noção seria desafiada na modernidade, como a noção de direitos dos homens e movimentos por esses ideais - Locke e Rousseau defenderam a democracia liberal, que tinha por base a razão, sendo, portanto, distante do direito divino.

Merecem destaque as ideias de Rousseau, que preconizava a universalidade dos direitos. Muito influenciaram essas ideias nas lutas políticas da época, sendo alicerce para os movimentos de independência de colônias americanas e de revoluções, tais como a Francesa e a Inglesa. Entretanto, nesse período, diante do fato de que a sociedade ideal apontava desigualdades sociais, a cidadania também foi tolhida, de certa forma, de seu sentido mais amplo. Os séculos XIX e XX foram responsáveis por progressos significativos que repercutiram no conceito de cidadania.

A Revolução Francesa e a Revolução Americana inseriram no contexto mundial um novo tipo de Estado, carregando consigo os ideais de liberdade e igualdade e, embora tivessem uma origem burguesa, auxiliaram na busca pela inclusão social. Aliadas a tudo isso, despontavam as lutas sociais. A cidadania passa, por fim, a manter íntima vinculação com o relacionamento entre a sociedade política e seus membros.

As duas guerras mundiais foram decisivas para a mudança do entendimento até então de cidadania, pois o medo advindo das atrocidades praticadas e alicerçadas pela legalidade fez com que órgãos internacionais e a própria sociedade civil passassem a entender cidadania como algo indissociável dos direitos humanos. A modernidade trouxe o conceito de indivíduo como categoria não só existencial, mas também jurídica e, com isso, a sobreposição da identidade individual sobre a coletiva (BOTELHO; SCHWARCZ, 2012). 
O conceito de cidadania passou a ser vinculado não apenas à participação política, representando um direito do indivíduo, mas também ao dever do Estado em ofertar condições mínimas para o exercício desse direito, incluindo, portanto, a proteção ao direito à vida, à educação, à informação e à participação nas decisões públicas.

Mesmo diante de todos esses avanços, ainda hoje se percebem as inúmeras violações aos direitos humanos e a ausência de cidadania plena a considerável parcela da população que ainda se vê excluída, em especial em países em desenvolvimento e cujas democracias ainda estão em construção.

Norberto Bobbio (1999) assegura que a cidadania é uma luta diária e que hoje não basta apenas elencar e fundamentar direitos, é preciso efetivá-los. Este é o desafio de nosso tempo. Cidadania no conceito moderno deixa de ser apenas o direito destinado ao indivíduo de participar ativa e passivamente do processo político. É mais que isso, é também o dever do Estado para com cidadão, dever de ofertar o mínimo existencial para garantir-lhe a dignidade. A cidadania requer, conforme a avaliação clássica de Marshall (1967, p.78), "um sentido direto de inclusão numa comunidade, baseado na lealdade a uma civilização que é propriedade comum".

Ao longo da história, o conceito de cidadania juntou-se à luta por direitos civis e foi apropriado pelos movimentos sociais que se organizavam a partir dos anos de 1970. A ideia de cidadania parecia, então, associar-se ao exercício pleno do Estado de direitos e ao convívio entre indivíduos e em sociedade, mas também ao direito às diferenças e de diferenças entre indivíduos, assim como se expressa na Constituição Federal.

Se cidadania pode ser entendida como um conjunto de direitos que, somados, garantem ao indivíduo o exercício de sua cidadania plena, é possível entender que a não expressão direta no texto constitucional reforça uma simbologia de menor cidadania ou subcidadania das pessoas LGBT, conceito este que trabalharei mais adiante. Seus múltiplos significados transitam em torno do universo de valores, práticas e reconhecimento de direitos, que, por sua vez, fornecem distintos conceitos e os limites do exercício da cidadania. Se cidadão significa fazer parte de um todo maior, cujos laços individuais se conectam a uma nação e o colocam como sujeito de direitos e deveres, e se esse "ser" é detentor legítimo de direitos e obrigações, essa cidadania nos sugere uma dinâmica de inclusão e exclusão, e o Estado, ao criar critérios para incluir, necessariamente, exclui outros.

Essa dinâmica de direitos e deveres, reivindicações e obrigações, excluir para incluir, cria atributos a determinados cidadãos, identificando alguns como cidadãos de "bem" e outros, 
cujas práticas e valores são estigmatizados, o título de maus cidadãos, ou não cidadãos, que prefiro trabalhar no conceito de subcidadania.

Jessé de Souza (2003), em sua obra A construção social da subcidadania: para uma sociologia política da modernidade periférica, trabalha a categoria em uma reflexão sobre o processo de modernização das denominadas sociedades periféricas. A referência central na construção de seu trabalho é o processo de desenvolvimento estrutural dos países periféricos, sendo o seu eixo as questões da modernização institucional, em particular do Estado racional; a criação do mercado competitivo; e a transformação progressiva das práticas sociais do Brasil sob o impacto das forças econômicas, sociais e culturais dos países centrais e das forças endógenas.

É possível compreender a mesma categoria de subcidadania para lésbicas, gays, bissexuais, travestis e transexuais, ainda que não seja possível distanciá-la do entendimento dialético de Estado e Mercado. A construção da cidadania LGBT também perpassa pelas relações entre Capital e Estado, pois em sociedades capitalistas em franco desenvolvimento, valores liberais que norteiam liberdades civis garantem o exercício da cidadania a pessoas LGBT pela lógica competitiva e capitalista, mas que não abarca a cidadania como um todo, pois os marcadores identitários não hegemônicos reforçam as interseccionalidades das vulnerabilidades, aproximando mesmo aqueles que na curva do capital estão pari passo com o horizonte liberal.

Compreender o processo de construção da cidadania passa também pela compreensão da articulação entre o processo de construção sócio-histórica dos valores morais e a dinâmica de interpretação inovadora da instituição das hierarquias sociais, com ênfase para a genealogia do Estado e do Mercado, identificados como práticas sociais, e o processo de incorporação dos valores que se tornaram hegemônicos, na modernidade, para o conjunto de classes sociais.

Esse processo gera a construção social da subcidadania, em que estabelece um sistema de hierarquia que contrapõe cidadãos a outros, que em sociedades em desenvolvimento tornase naturalizada. Essa naturalização se constitui como uma ideologia espontânea, que fundamenta e legitima o conjunto de hierarquias entre os indivíduos e classes. No caso das sociedades ocidentais, cabe, todavia, aos capitais econômico e cultural o papel de instrumentos estruturantes das relações de dominação e sua reprodução, ao contrário das sociedades pré-modernas, que se baseiam no capital social.

Entender essa construção histórica de desigualdades, que Charles Tilly (1999) chama de duradouras e de subcidadania, possibilita-nos compreender as categorias binárias e contrapostas sustentadas por mecanismos de reprodução, tais como a exploração, as barreiras 
de controle, a emulação e a adaptação (GUIMARÃES, 2011; SOUZA, 2003). Exemplo disso são os binarismos que sustentam as desigualdades sociais duradouras que reproduzem os mecanismos citados, como: branco/negro; homem/mulher; heterossexual/homossexual; cristãos/não cristãos etc. (GUIMARÃES, 2011).

Devido a isso, o princípio da dignidade humana para todos os cidadãos não foi incorporado ao conjunto das classes sociais, construindo-se uma hierarquia social que ignora a igualdade como princípio das suas relações, do funcionamento do Estado e do Mercado. Dessa forma, seguindo os valores da modernidade e o pensamento liberal, as diferenças de classe são legítimas desde que o princípio da igualdade de oportunidades seja respeitado.

As sociedades modernas dos continentes colonizados podem ser descritas sucintamente por alguns traços gerais: o Estado-Nação, o capitalismo, a forma industrial de organização da produção, a convivência e sociabilidade urbanas, e os valores jurídicos constitucionais de liberdade e igualdade. Tais traços, tão somente, não eliminam seus contrários: solidariedades étnicas, formas pré-capitalistas de produção, a vida rural ou as hierarquias sociais (GUIMARÃES, 2011).

A desigualdade estabelecida pela hierarquia social coloca como elemento central das relações sociais a violência que empurra para a marginalidade determinados grupos, que tanto são vitimizados quanto usam de sua prática - comunicar-se com demais grupos e agentes sociais. Assim, o desenvolvimento institucional da nova periferia não foi detido pela presença de resíduos personalistas, patrimonialistas ou familistas do passado, visto que estes não geraram uma visão de mundo articulada institucional e simbolicamente, homogênea a todos os grupos e classes sociais. O que caracterizou, então, o processo de modernização brasileiro e periférico foi antes a ausência de valores fundamentais para a constituição do capitalismo ocidental do que a força inerte dos resíduos do passado.

Assim, no que diz respeito à organização social, as hierarquias, os privilégios, as deferências e os outros modos de expressão das desigualdades passaram, para serem aceitos, incluídos, a depender de outras lógicas de construção e justificação.

Da mesma forma, a difusão de políticas públicas estruturantes, como saúde, educação e cultura, bem como políticas sociais que buscam incluir cidadãos excluídos, não são capazes de promover a cidadania por si só. É preciso buscar, como fica evidente na compreensão do autor, a produção de novas formas de reconhecimento do processo de reprodução social, a fim de se construir uma sociedade que seja capaz de reconhecer a existência de apenas um (tipo) cidadão. 
Para complementar esse entendimento, uso a teoria de cidadania de Michel Walzer (1975), pois encontrei no autor uma importante alternativa à visão tradicional de cidadania, articulando no seu âmbito a problemática da desobediência civil e dos limites do poder de Estado. A posição de Walzer é eminentemente política e não meramente jurídica, mostrando a importância, para as sociedades contemporâneas, de criar espaços de mediação entre o Estado e o cidadão. Se a cidadania tem uma componente de participação e de proteção, ela é bem mais complexa, podendo reconhecer outros direitos, como os da não participação ou da desobediência civil. Por fundamental que os direitos sejam, tendem a ser negados quando essas mediações não são suportadas por associações e grupos de todo o tipo, mais ou menos efêmeros, que emergem da concreticidade e da pluralidade da ação social. Mas, como diz Hannah Arendt (2010, p.67) "É na experiência da pluralidade e da diversidade entre perspectivas diferentes - que, porém, pode levar ao entendimento e ao consenso - que o significado primeiro da esfera pública pode ser encontrado".

Walzer (1975) nomeia a existência de diferentes tipos de cidadania: o cidadão oprimido, cujas obrigações dependem de como ele decide envolver-se na comunidade que vive; cidadão isolado, que é protegido pelo Estado, mas que prefere não participar da vida política; e o cidadão pluralista, que recebe a proteção do Estado, mas que participa do governar e ser governado.

Nesse sentido, o entendimento de cidadania não está centrado no cidadão, mas sim no Estado, tendo em vista a necessidade de estabelecer o movimento dialético do capital e daqueles que o servem, por isso faz-se necessário centrar-se sobre o cidadão e não sobre o estado, com a separação implícita entre política e direito pressuposto da noção de "desobediência civill, e mostra a necessidade de outra concepção de cidadania como descrita por Walzer, que ainda reforça que, no Estado Democrático Moderno, a noção de cidadania aparece associada a três valores essenciais: proteção, responsabilidade e participação.

Essa tríade descrita por Walzer parte do pressuposto de que a proteção é dada pelo Estado e em um exercício lógico; se considerarmos os cidadãos de determinado Estado ou grupo, partimos do princípio de que os agentes de Estado têm a obrigação de protegê-los, em contrapartida, a proteção do Estado incumbe ao indivíduo a responsabilidade, exige desse grupo ou de cidadãos a obediência às suas leis, tornando-os subservientes em troca da proteção, como, por exemplo, em estado de guerra, ao dever de morrer ou viver pelo Estado, regredindo, inclusive, em concepções já estabelecidas de cidadania. O terceiro valor é o da participação, que não se resume à escolha dos governantes, mas sim do indivíduo. 
Para Hannah Arendt (1989), a desobediência civil, ao contrário de uma posição tão somente anárquica, é a possibilidade de recuperar o poder em seu sentido pleno e da autoridade embasada na dimensão política da liberdade de ação em comum. Por isso, o fundamento da desobediência civil é a preocupação com o mundo, que se vê ameaçado em sua liberdade por um sistema que quer promover a ruptura com o contrato social, para a legitimação de sua dominação. Dessa forma, esse tipo de ação gera um novo poder.

De toda maneira, a cidadania vai se transformando, cada vez mais, numa escolha moral e não apenas num status legal. Isso porque os significados sobre direitos e cidadania mudam o tempo todo, bem como porque imensas são as parcelas da população que ainda não acessam seus direitos, uma história que evolui combinando mudanças e persistências, desafios e lutas, modernidade com atraso, inclusão com exclusão.

Dessa forma, faz-se necessária participação para que ações possam reforçar as identidades de cidadãos cada vez mais sem voz, construindo cidadanias diversas à relevância do Estado. Apresentar-se por meio da ação e do discurso é revelar ao mundo a própria identidade; aparecer de modo que a realidade do mundo passa a ser assegurada pela presença do outro. Nesta relação fenomenológica, ao aparecer para o outro, este aparece a mim, como outro, na sua maneira própria de ser, diversa da minha, ou seja, na sua singularidade.

Portanto, o lugar privilegiado do aparecimento é o espaço público; não entendendo este como local geográfico, mas como o espaço no qual as pessoas estabelecem relações e se organizam por meio do discurso e da ação em conjunto, independentemente de onde estiverem. A ação política, nascida nesse espaço público, como bem demonstraram os gregos, surge como uma necessidade de diálogo entre essas "universalidades particulares", que são os homens. Assim, "a política trata da convivência entre diferentes. Os homens se organizam politicamente para certas coisas em comum, essenciais num caos absoluto, ou a partir do caos absoluto das diferenças" (ARENDT, 2002, p.21-22).

É importante frisar a relevância que Hannah Arendt (2002) atribui à dimensão do diálogo, pois, para que este exista, é preciso que prevaleçam alguns critérios: seres de capacidade racional-simbólica, portanto humanos; livres, que se entendam entre si e se manifestam igualmente e que, ao mesmo tempo, apresentam diversidade de ideias, pensamentos, modos de ser, entre outros, que formam identidades diversas. Logo, entre seres, paradoxalmente "igualmente plurais". A pluralidade humana, condição básica da ação e do discurso, tem o duplo aspecto da igualdade e da distinção (ARENDT, 2010).

É importante perceber que essa ameaça de ruptura e a desobediência como reação a ela ocorrem na esfera do público, local da política, onde a cidadania, como o direito a ter direitos, 
encontra sua legitimidade. Porém, Arendt (2010) demonstra que é preciso, ainda na esfera de uma discussão sobre direitos humanos, a reafirmação da diferença entre espaço público e privado, tanto para assegurar a ação em comum, pautada na liberdade, quanto para estabelecer o direito individual, singular e privado. Este, portanto, constitui-se no direito de estar só, tendo a singularidade e a possibilidade de excluir do conhecimento de terceiros aquilo que só a ela se refere e diz respeito à sua maneira de ser no âmbito da vida privada. É por meio desses encontros pessoais que se descobre sua singularidade, fazendo com que se perceba diferente dos outros. Tal percepção cria a possibilidade da afirmação de sua identidade e o indivíduo observa a existência de outras, concebendo, assim, a pluralidade e a necessidade de convivência em comum.

É também por meio dessa percepção que, ao assegurar sua identidade, o ser humano foge do nivelamento social, da massificação, necessária a qualquer dominação. O fundamento, portanto, para o direito à intimidade é a exclusividade. Esta, que se diferencia do direito à informação (direito humano na esfera do espaço público, como acesso de todos àquilo que se refere a ele, permitindo uma adequada, autônoma e igualitária participação dos indivíduos na esfera pública, evitando o efeito deletério da mentira), é o que mantém longe de terceiros aquilo que é próprio, exclusivo ao indivíduo. É também colaboradora da esfera pública, pois ajuda a delimitar o que concerne a cada espaço. A invasão desse direito e a consequente emergência do que é íntimo ao público ocorrem na banalização de ambas as partes.

Nesse contexto, ouvir as vozes lésbicas para construção da cidadania é propiciar espaço de participação, ouvir e ser ouvida, transitar do privado para o público, dar amplidão e conhecimento ao modo de vida que privilegia o nós ao invés do eu e, ainda, preserva o espaço privado como espaço íntimo e o público como espaço de afirmação de identidade, de visibilidade e de voz.

\subsection{A Cidadania na Constituição Federal de 1988}

Ao afirmar que todas e todos são iguais perante a lei, a Constituição Brasileira estabelece de modo inédito que mulheres e homens são sujeitos de direitos plenos em condição indiscutível de igualdade perante os demais. As nossas Constituições sempre reconheceram o princípio da igualdade, mas a legislação ordinária, por muito tempo estabeleceu regras marcadas pela desigualdade entre mulheres e homens (MIRANDA, 2011). 
A Constituição Federal de 1988 estabelece, de forma supraconstitucional, em preceitos fundamentais, a igualdade de mulheres e homens.

Segundo Dagnino (2004), a Carta Magna se tornou o marco legal da participação da sociedade civil no processo de construção da democracia no país, onde teve, desde meados de 1980, a participação dos movimentos sociais no projeto democrático de país. Para Coutinho (2000), uma concepção básica de democracia define que esta é a "presença efetiva de condições sociais e institucionais que possibilitam ao conjunto dos cidadãos a participação ativa formação do governo e em consequência, no controle da vida social" (COUTINHO, 2000, p. 27).

Ciconello (2008) descreve o processo da CF/1988 a partir de um conjunto plural de influências de diversos atores políticos e sociais na construção do Estado Democrático de Direito, bem como o desenho dos princípios e de diretrizes da participação social no processo de construção e controle social das políticas públicas de Estado. E ainda relata que é por essas razões que a Carta Magna foi batizada de "Constituição Cidadã", considerando a forte participação dos movimentos sociais. Todo esse esforço de movimentos sociais e constituintes culminou na aprovação de um texto jurídico que ficou conhecido como a Constituição Cidadã. Por isso, parto do pressuposto de que a matéria aprovada tem subsídios suficientes para tornar indivíduos sujeitos de direitos e cidadãos.

Para Gohn (2008), a participação social coletiva refere-se a ações sociais coletivas de caráter sociopolítico e cultural, que viabilizam formas distintas de a população se organizar e expressar suas demandas. Segundo a autora, os movimentos sociais no Brasil se organizaram a partir da luta contra a ditadura militar e, mesmo que haja uma mudança em relação a isso nos governos posteriores, ela considera que os movimentos sociais na década de 1970 e 1980 no país contribuíram de forma decisiva "[...] via demandas e pressões organizadas, para a conquista de vários direitos sociais, que foram inscritos em leis na nova Constituição Federal de 1988" (GOHN, 2011, p.10).

Em certo momento de sua narrativa em Raízes do Brasil (1936), Sérgio Buarque de Holanda diz que a democracia no Brasil é um lamentável mal-entendido. Ainda que esse pensamento tivesse por contexto a época em que foi escrito, na qual, na ordem vigente, a aristocrata rural, semifeudal e burguesa estabelecia direitos para seu próprio proveito e se constituía numa categoria de "cidadãos" privilegiados e com status diferenciado, o que observamos nos atuais dias não é muito diferente do que ocorria em 1936. Obviamente, a sociedade nos dias de hoje não é a mesma que à época, mas a elite, os ruralistas, conservadores e, mais recentemente, religiosos fundamentalistas vislumbram uma sociedade 
que poderia dar-lhes um status diferenciado e quiçá, privilégios. Os anos que sucederam o fim da ditadura revelavam a forte mobilização social e política para a redemocratização do país, porém os setores que apoiaram a ditadura ainda tinham uma forte influência no cenário político brasileiro e forte representação política entre os parlamentares durante a Assembleia Nacional Constituinte (ANC).

A ANC, convocada pela Emenda Constitucional $\mathrm{n}^{\mathrm{o}} 26$, de 1985 , foi instalada em $1^{\circ}$ de fevereiro de 1987, sendo composta por 487 deputados federais e 49 senadores eleitos em 15 de novembro de 1986, somados aos 23 dos 25 senadores eleitos em 1982, totalizando 559 parlamentares, que concluíram os trabalhos em 5 de outubro de 1988, quando foi promulgada, em sessão solene, pelo seu presidente, deputado federal Ulysses Guimarães, a Constituição Federal.

Não há informações sistematizadas sobre o perfil dos parlamentares que compunham a ANC. O estudo coordenado por Said Farah (MARCELINO et al., 2009) aponta a correlação de forças na Constituinte a partir do mapeamento das fichas individuais sobre o perfil social e ideológico de cada um dos constituintes eleitos em 1986. O estudo revelou que havia quatro principais forças representadas na Constituinte: o grupo majoritário, composto por $35 \%$ de deputados e senadores constituintes; os liberais-conservadores, a direita, representada com $25 \%$ dos parlamentares constituintes; os liberais-reformistas, com $21 \%$, e um grupo menor de parlamentares de esquerda, com $12 \%$.

A promulgação da $\mathrm{CF} / 1988$ foi um importante marco do longo processo de transição entre a ditadura e o regime militar para a democracia no Brasil (GOMES, 2006). Esses momentos de transição e mudanças foram significativos à sociedade e foram marcados por disputas de projetos e perspectivas sobre o que viria com a nova Constituição, a Constituição que marcaria a democracia no país. Os trabalhos da Constituinte foram divididos com as atividades parlamentares e congressuais de rotina. Entre os mais entusiastas, havia os que radicalizavam em propostas em contraponto às forças mais conservadoras majoritárias, mesmo não considerando a possibilidade de logro de sua assimilação na Constituinte. Havia os que eram progressistas, porém realistas, e, portanto, negociavam no processo visto a correlação de forças, sem transigir no que era fundamental (BRANDÃO, 2011).

De toda forma, a possibilidade de apresentar emenda popular, ainda que num processo restrito com as regras impostas, foi fundamental para que os anseios da população e dos movimentos sociais fossem atendidos na Constituinte.

Ao final da construção da nova carta constitucional, votações, pressão popular, negociações e incidências de todos os setores da sociedade se refletiram na Carta Magna, com 
algumas das demandas dos movimentos sociais conjecturadas, outras rejeitadas e não expressadas no novo documento e as que se apresentaram no texto de forma diversa ao demandado pela sociedade civil. O período também foi marcado pela organização da sociedade civil, que se fortaleceu nesse processo, requalificando sua atuação e incidência com os representantes parlamentares, possibilitando um processo de transição democrática, favorecendo, inclusive, a criação de meios de participação popular até então inéditos no mundo (BRANDÃO, 2011).

A Carta Magna tem como um de seus preceitos fundamentais o princípio da dignidade humana, que complementado pelo art. $5^{\circ}$ da $\mathrm{CF} / 1988$, por si só deveria tornar mulheres e homens, crianças e adultos, homossexuais e heterossexuais, não religiosos e religiosos, negros e brancos, índios e não índios iguais em dignidade e direitos. Mas, ainda assim, o mesmo texto trouxe à época de sua aprovação, como absoluta prioridade, os direitos de crianças e adolescentes em relação a outras pessoas. Além disso, observa-se também que homossexuais não tiveram seus direitos assegurados na carta política, o que nos faz pensar que isso tenha acarretado e sistematizado um sistema de prioridades em direitos, produzindo uma hierarquia de opressões, favorecendo a uma parte da população com mais garantias do que as outras.

Ao explorar ainda mais o texto, a palavra cidadania aparece sete vezes, e se formos observar suas variações, cidadão(s), cidadã(s) a soma supera uma centena de vezes. A primeira vez, e talvez a mais importante, no art. $1^{\circ}$, como princípio fundamental do Estado Democrático de Direito que garante a soberania, a cidadania, a dignidade da pessoa humana, os valores sociais do trabalho e da livre iniciativa e o pluralismo jurídico.

No capítulo I, que trata dos direitos e deveres individuais e coletivos, onde é discorrido o art. $5^{\circ}$, que diz que todos são iguais perante a lei, cidadania aparece quando da prerrogativa de fazer valer a cidadania, a soberania e a nacionalidade por ausência de norma regulamentadora por meio de instrumento judicial. Seguindo o texto, o termo aparece como competência privativa da União em legislar sobre nacionalidade, cidadania e naturalização. Também no art. 62, quando do tema de medidas provisórias, que veda a edição de medidas para matérias relativas à cidadania, entre outras. Ato análogo previsto no art. 68 , que delega como exclusividade do Congresso Nacional as legislações que tratem de nacionalidade, cidadania, direitos individuais, políticos e eleitorais. No capítulo III, na seção I, Da educação, cidadania é expressa no art. 205, que coloca a educação como dever do Estado e da família, como parte necessária para o pleno desenvolvimento e seu exercício.

Apesar de a palavra cidadania ser a expressão resumida da nossa Carta Magna e a sua luta e parte central na atual agenda política brasileira, não há uma definição conceitual única 
entre os diversos pesquisadores e pesquisadoras, como vimos na seção anterior. Também é explícito que não há unanimidade entre as mulheres entrevistadas, bem como a questão da cidadania parece ser a bandeira mais central da luta do movimento LGBT. Mas de que cidadania falamos? 


\section{CAPÍTULO 2}

\section{A BUSCA PELA CIDADANIA LGBT}

A luta por direitos LGBT no Brasil e no mundo passa necessariamente pelo reconhecimento das identidades, pelo direito à diferença. Direito ao casamento igualitário, enfrentamento à violência, direitos à adoção, à herança, todos são precedidos pelo direito de existir e pelo direito ao reconhecimento. Parto da ideia de que o movimento LGBT no Brasil e sua busca por cidadania tem como base a luta por reconhecimento. Nesse sentido, é estabelecida uma ideia de reconhecimento que percebe o indivíduo enquanto membro de uma comunidade nacional e enquanto membro de um grupo cultural específico (PIOVEZAN, 2005).

Muitos dos grupos historicamente discriminados, como os que lutam pelo reconhecimento a raça, etnia, sexo, expressão de gênero, sexualidade, orientação sexual e identidade de gênero, reivindicam cada vez mais o direito de serem reconhecidos como negro, índio, homossexual, travesti, em vez de proletário ou burguês (identidade de classe). Piovezan (2005) reflete que grupos sociais vulneráveis, como negras e negros, mulheres, crianças e adolescentes, população LGBT e demais grupos, devem ser vistos nas suas especificidades e peculiaridades de sua condição social. Continua afirmando que, ao lado do direito à igualdade, surge também, como direito fundamental, o direito à diferença. Importa o respeito à diferença e à diversidade, o que lhes assegura um tratamento especial.

Ainda que nossa Carta Maior, em seus preceitos fundamentais, estabeleça igualdade de direitos e o princípio da não discriminação, essa noção de identidade global não tem garantido os direitos das consideradas minorias. A universalidade como direito invisibiliza as diferenças e só serve como política de identidade globalizada, fortalecendo a estratégia imperialista para intervir, com certa dignidade, em corpos e identidades culturais (SEGATO, 2007).

Para Segato (2007), “a defesa das autonomias culturais e as lutas pela ampliação dos direitos das mulheres, dos negros, dos indígenas e dos diferentes, não como resultado de intervenção ocidental, mas, sim, a partir de um horizonte autônomo das culturas" (SEGATO, 2007, p. 17). Contudo, deve-se buscar uma visão progressista dos direitos humanos com vistas a garantir as identidades culturais.

A universalidade dos direitos humanos pode tornar invisível alguns aspectos como a sexualidade, pois o reconhecimento importa para a afirmação dela. Tanto que percebemos que 
os princípios de igualdade formal foram sendo acrescentados de princípios de igualdade de gênero e combate à discriminação que atinge as mulheres.

Para além dos seus parâmetros iniciais, os direitos humanos hoje englobam especificidades que antes eram marginais nas especificações universais (CRENSHAW, 2002). A incorporação da perspectiva de gênero em tratados de direitos humanos (em grande parte, internacionais), é fruto da luta de mulheres organizadas. Em menor proporção, o debate sobre raça vem sendo incorporado a princípios de não discriminação, e ressaltamos que não vimos essa abrangência sobre a orientação sexual. Entendemos que estes devem ser debates interseccionados, pois importa gênero (incluindo identidade de gênero), raça e orientação sexual. As discriminações operam juntas, e precisamos avançar para a visibilidade da discriminação interseccional dentro dos movimentos sociais e das políticas públicas (CRENSHAW, 2002).

Dessa forma, em reflexo à ordem global dos direitos, podemos entender que o ordenamento jurídico brasileiro é um sistema de prioridades em direitos, produzindo uma hierarquia de opressões, visto que favorece a hegemonia no sentido gramsciniano, fornecendo a uma parte da sociedade mais direitos do que outros, fortalecendo o sistema de dominação (GRAMSCI, 1978).

O movimento LGBT apoia suas bandeiras em um movimento contra-hegemônico, que vem na contramão do grupo que controla e mantém o controle político, coroando essa hegemonia que se representa no congresso como espelho da sociedade na manutenção do poder masculino, branco e heterossexual (SAFFIOTI, 2004). A negação de direitos pela sociedade heterossexual, branca e patriarcal e a estigmatização social da população LGBT faz parte de uma estrutura mais ampla, que opera na manutenção de privilégios e na concentração de poder político e econômico por determinados grupos sociais (TERRA; PRADO, 2014).

Esse mesmo sentido hegemônico pode-se observar internamente entre pessoas LGBT e sua disputa política, entre os que se definem gays, mas não pintosa, ${ }^{4}$ revelando uma aversão ao feminino e tudo o que dele se aproxima, relevando hostilidade a um grupo de indivíduos que estão à margem das normas sexuais (BORRILLO, 2010).

4 Pintosa é uma gíria entre homossexuais masculinos que descrevem aqueles mais femininos e que renegam sua masculinidade, contudo, inclusive usando um vocabulário feminino, chamando-se de senhora, de bicha etc. No sentido contrário, o gay seria o homem com orientação sexual homossexual e que se admite relacionar-se com homem, mas não associar-se ao feminino. 


\subsection{Luta e Organização Política do Movimento LGBT no Brasil}

Um evento importante de resistência LGBT é a conhecida Revolta de Stonewall, quando o dia 28 de junho de 1969 ficou marcado na história da luta pela cidadania. Nesse dia, lésbicas, gays e pessoas trans ${ }^{5}$ resistiram à prisão e protagonizaram um cenário de guerra durante quase uma semana de resistência, de luta pelo direito de ser e marcado no calendário mundial como dia do Orgulho LGBT. Esse evento também conhecido como a resistência do movimento homossexual estadunidense que disse não, não à clandestinidade, não ao armário e não à vergonha imputada pela medicina psiquiátrica, que nos carimbava como desviados, foi o grito da liberdade, o grito da cidadania.

Nos finais da década de 1970, as cidades de São Paulo e do Rio de Janeiro viram surgir as primeiras formações do ativismo e movimento homossexual, seja pelo lançamento do Jornal Lampião da Esquina, seja pela organização do Grupo SOMOS, ${ }^{6}$ que determinam as formas que essa política devia assumir com vistas à inclusão dos homossexuais como sujeitos de direito. Foi em torno da questão da legitimidade que a organização política da homossexualidade se produziu entre nós.

Imprescindível dizer que, somente em 1973, a Associação Americana de Psiquiatria deixou de classificar a homossexualidade como doença, e na mesma época foi retirado do Código Internacional de Doenças (CID), mas foi somente em 17 de maio de 1990, numa Assembleia Geral da ONU, que a OMS retirou a homossexualidade da lista de doenças mentais e, desde então, o sufixo "ismo" passou a ser considerado não grato aos ativistas do movimento homossexual, mesmo que seu significado transite positivamente entre as ciências sociais (positivismo, marxismo etc.). ${ }^{7}$ As próprias palavras de Houaiss (2001) expõem essa produtividade com esse sufixo. Ele afirma que seu uso na medicina é para designar uma intoxicação de um agente obviamente tóxico: absintismo, alcoolismo, ergotismo, eterismo, hidrargirismo, iodismo, e, com isso, notoriamente, remetendo-nos a doença.

Os anos seguintes, no Brasil e no mundo, movimentos se organizaram, e mesmo acometidos pela Aids, resistiram, e cada vez mais nos acostumamos com as Paradas e Marchas do Orgulho LGBT e, mais recentemente, com as Caminhadas de mulheres Lésbicas

5 A participação de lésbicas e pessoas trans sempre foi negligenciada na história. Atualmente diversas pessoas tentam recontar a história.

6 Explorados no capítulo anterior, mas aqui usado para dar sentido à ligação da construção do movimento com a busca da cidadania.

7 Por esta razão, o dia ficou conhecido como Dia Internacional de Combate a Homofobia, no Brasil, o dia 17 de maio foi instituído por Decreto Presidencial de 4 de junho de 2010, pelo então presidente Lula como Dia Nacional de Combate à Homofobia, 
e Bissexuais que se multiplicam no país, saindo das capitais e tomando conta do interior do país.

A fundação do movimento homossexual no Brasil em 1978 é marcada pela criação do Núcleo de Ação pelos Direitos dos Homossexuais em São Paulo, que logo se tornou conhecido como SOMOS - Grupo de Afirmação Homossexual (SIMÕES; FACCHINI, 2009). Nessa ocasião, explodia no país a organização de trabalhadores, estudantes, mulheres, negros e homossexuais pelo fim da ditadura e por melhores condições de trabalho, mais direitos e igualdade (GREEN, 2003; FACCHINI, 2003).

A organização do SOMOS ocorreu após um debate em 6 de fevereiro de 1979, no Departamento de Ciências Sociais na Universidade de São Paulo (USP), que reuniu mais de 300 pessoas em seu auditório (FACCHINI, 2003). Na época, o grupo ainda majoritariamente gay, passou a contar com a presença de lésbicas que, convidadas a participar do grupo, passaram a frequentar as reuniões dois dias após a realização do debate. Foi então que organizaram um subgrupo dentro do SOMOS, o LF (Lésbicas Feministas) com o objetivo de discutir o que era ser lésbica.

Nesse período, surgia no Brasil a epidemia de Aids (Acquired Immunodeficiency Syndrome ou Síndrome da Imunodeficiência Adquirida - SIDA). O primeiro caso foi em São Paulo, em 1980, porém só foi confirmado em 1982. Apesar de o Brasil diagnosticar seu primeiro caso em mulheres, em 1983, no período final do regime militar, a doença crescia vertiginosamente entre pessoas homossexuais que, invisíveis em sua condição cidadã, foram as mais afetadas pela doença (ROSSI, 2002) ficando estigmatizada como peste gay. A epidemia forçou o Ministério da Saúde a criar o Programa Nacional de Doenças Sexualmente Transmissíveis - DST e Aids, em 1986, e no ano em que a Constituição Federal foi promulgada o Brasil já acumulava 4.535 casos. $^{8}$

O surgimento da Aids evidenciou as sexualidades, principalmente a homossexualidade, marcando a discussão da vida sexual no Brasil moderno. Tornou-se um marco para discussão de políticas públicas progressistas com protagonismo de lideranças feministas e homossexuais como os principais ativistas da luta contra a Aids, tornando-se oportunidade para a organização do movimento homossexual brasileiro pela defesa da diversidade sexual (PARKER, 1991).

No período agudo da epidemia, o movimento homossexual encerra sua primeira fase com a redução da maior parte dos grupos e, com isso, surgem os grupos Triângulo Rosa e Grupo Gay da Bahia (GGB), fundados por João Antônio Mascarenhas e Luiz Mott,

8 Disponível em: <http://www.aids.gov.br/pagina/historia-da-aids〉. Acesso em: 5 jan. 2016, às $12 \mathrm{~h} 30$. 
respectivamente (SIMÕES; FACCHINI, 2009). Mascarenhas também fundou, somado a escritores e intelectuais, o Jornal Lampião da Esquina, mantendo-se na ativa de abril de 1978 a junho de 1981, com 38 edições, incluindo o número zero, considerado experimental. Ainda protagonizou a participação do movimento homossexual na Assembleia Nacional Constituinte (ANC), como será chamada a partir deste ponto (HOWES, 2003).

As lutas dos ativistas na década de 1980 foram marcadas pelo enfrentamento à epidemia de Aids, com a instituição de organizações de enfrentamento à epidemia, como o GAPA (Grupo Pela Vida), o protagonismo de Brenda Lee, as campanhas para o registro jurídico das organizações de homossexuais, pela retirada da classificação do homossexualismo como desvio e transtorno sexual no parágrafo 302.0 da Classificação Internacional de Doenças da Organização Mundial de Saúde (OMS), pela proibição de discriminação por orientação sexual no Código de Ética dos Jornalistas e na Constituição Federal de 1988 (HOWES, 2003).

Ausente no olhar do poder público e da sociedade, um grupo de 100 (cem) lésbicas e mulheres bissexuais reuniu-se no Rio de Janeiro para o I Seminário Nacional de Lésbicas (Senale), ocorrido em 1996. Dentre os temas principais deliberados nesse encontro, o cuidado com a saúde sexual foi o passaporte para o diálogo com setores do governo. No mesmo ano, a Coordenação Nacional de DST-Aids, vinculada ao Ministério da Saúde, convidou lideranças lésbicas para discutir as demandas em saúde sexual numa instância de interlocução permanente conhecida como Grupo Matricial, empoderando a vivência lésbica como identidade pela primeira vez, ainda que os resultados do grupo, conforme apontados em estudos, não tenham sido os esperados pelo movimento de lésbicas (ALMEIDA, 2005; FACCHINI, 2008).

Os debates pelo reconhecimento da cidadania e por direitos se refletem também no legislativo, com a apresentação do projeto da então deputada federal Marta Suplicy, o Projeto de Lei $\mathrm{n}^{\circ}$ 1.151, de 1995, da Parceria Civil Registrada, que promoveu um debate amplo, porém muito pautado em dogmas religiosos, como observados na fala do então presidente da Câmara dos Deputados, deputado Severino Cavalcanti, em 10 de dezembro de 1996: “O projeto, pelo contrário, leva os culpados a uma certa tranquilidade dentro do pecado", ou, ainda, em dogmas psicopatológicos, como denotados na fala do deputado Salvador Zimbaldi, em 6 de agosto de 1996: "Era considerada uma doença e já não é mais. Por outro lado, na nossa opinião, continua sendo uma anomalia" (LOPES, 2006).

O projeto que foi apresentado para disciplinar a união civil entre pessoas do mesmo sexo, em 1996, sofreu enorme pressão dos setores conservadores e religiosos, incluindo do 
presidente da Câmara. Por ato de sua presidência, decide constituir Comissão Especial em 12 de junho de 2006, resultando em parecer favorável de seu relator, deputado Roberto Jefferson, com apresentação de substituto que alterou profundamente o projeto de união para parceria civil, retirando qualquer menção a vínculos afetivos e vetando qualquer hipótese de adoção, tutela ou guarda de crianças ou adolescentes ainda no mesmo ano (SIMÕES; FACCHINI, 2009).

Em maio de 2004, o governo brasileiro lançou o "Brasil Sem Homofobia: Programa de Combate à Violência e à Discriminação contra GLTB e de Promoção da Cidadania Homossexual", vinculado à então Secretaria Especial de Direitos Humanos, acompanhado pelo Conselho Nacional de Combate à Discriminação ${ }^{9}$ e viabilizado também pelo Ministério da Saúde. Tal documento é o resultado de uma revisão do documento final do IX Encontro Brasileiro de Gays, Lésbicas e Transgêneros (EBGLT), realizado em Manaus, em novembro de 2003. Importante destacar que o EBGLT de Manaus se tornou um divisor na relação do movimento LGBT com o governo federal, que antes se limitava à agenda da Aids e a raras ações no Ministério da Justiça, como o balcão de direitos, e, após o encontro, com a participação em diversas outras agendas propiciadas pelo então Programa Brasil sem Homofobia (FERNANDES, 2011). ${ }^{10}$

Durante o processo de implantação do programa Brasil sem Homofobia, o movimento LGBT ampliou o debate sobre políticas públicas com diversos atores governamentais, que culminou na convocação da I Conferência Nacional de Políticas Públicas e Promoção da Cidadania LGBT, iniciativa inédita no mundo, ocorrida em junho de 2008, que contou com a participação na abertura do então presidente Lula.

Como resultado da conferência, as propostas aprovadas em sua plenária final se transformaram no I Plano Nacional de Promoção da Cidadania e Direitos Humanos LGBT, lançado em 2009, integrando um conjunto de ações que ficou conhecido pelo movimento como tripé da cidadania LGBT, ${ }^{11}$ somado à criação da Coordenação Nacional de Políticas

9 O CNCD foi criado pelo Decreto $n^{\text {o }} 3.952 / 2001$, no âmbito do Ministério da Justiça, como resposta à ratificação do Brasil à Declaração da Conferência de Durban (Conferência Mundial de Combate ao Racismo, Discriminação Racial, Xenofobia e Intolerância Correlata). Em 2005, passa a ser vinculado à então Secretaria Especial de Direitos Humanos e, em 2010, foi transformado em CNCD-LGBT pelo Decreto 7.388 do mesmo ano.

10 Balcão de Direitos foi uma ação do PPA 2000-2003 do governo FHC, que pretendia uma atuação comunitária jurídica para populações mais vulneráveis e tinha uma linha específica de enfrentamento às violências contra LGBT.

11 Nome adotado pelo movimento LGBT após a realização da I Conferência Nacional de Políticas Públicas e Cidadania LGBT, que aprovou as propostas de promoção da cidadania. O tripé em questão seria composto: por órgão gestor, conselho de controle social da política LGBT e plano de política pública. O tripé é citado novamente na II Conferência. 
LGBT no âmbito da Secretaria de Direitos Humanos da Presidência da República e depois a instituição do Conselho Nacional de Combate à Discriminação e Promoção dos Direitos de LGBT, em 2010.

Em 2011, os ministros do Supremo Tribunal Federal (STF), ao julgarem a Ação Direta de Inconstitucionalidade (ADI) 4.277 e a Arguição de Descumprimento de Preceito Fundamental (ADPF) 132, reconheceram a união estável para casais do mesmo sexo. As ações foram ajuizadas na Corte, respectivamente, pela Procuradoria-Geral da República e pelo governador do Rio de Janeiro, Sérgio Cabral. O julgamento se iniciou em 04 de maio, quando o relator das ações, ministro Ayres Britto, votou no sentido de dar interpretação, conforme a Constituição Federal, para excluir qualquer significado do art. 1.723 do Código Civil que impeça o reconhecimento da união entre pessoas do mesmo sexo como entidade familiar.

$\mathrm{O}$ ministro Ayres Britto argumentou que o art. $3^{\circ}$, inciso IV, da CF veda qualquer discriminação em virtude de sexo, raça, cor e que, nesse sentido, ninguém pode ser diminuído ou discriminado em função de sua preferência sexual. "O sexo das pessoas, salvo disposição contrária, não se presta para desigualação jurídica", observou o ministro, para concluir que qualquer depreciação da união estável homoafetiva colide, portanto, com o inciso IV do art. $3^{\circ}$ da CF. Os ministros Luiz Fux, Ricardo Lewandowski, Joaquim Barbosa, Gilmar Mendes, Marco Aurélio e Celso de Mello, bem como as ministras Carmen Lúcia Antunes Rocha e Ellen Gracie, acompanharam o entendimento do ministro Ayres Britto, pela procedência das ações e com efeito vinculante, no sentido de dar interpretação, conforme a Constituição Federal, para excluir qualquer significado do art. 1.723 do Código Civil que impeça o reconhecimento da união entre pessoas do mesmo sexo como entidade familiar. Décimo e último ministro a votar, o então presidente do Supremo Tribunal Federal (STF), ministro Cezar Peluso, convocou o Poder Legislativo a assumir a tarefa de regulamentar o reconhecimento da união estável para casais do mesmo sexo. Ele também acompanhou o relator, ministro Ayres Britto, no sentido de julgar procedentes a Ação Direta de Inconstitucionalidade (ADI) 4.277 e a Arguição de Descumprimento de Preceito Fundamental (ADPF) 132. Com o seu voto, como presidente da Corte, o Plenário do STF reconheceu por unanimidade (dez votos) a estabilidade da união homoafetiva, decisão que tem efeito vinculante e alcança toda a sociedade.

Após a decisão do STF, diversos casais de homossexuais passaram não só a realizar suas uniões civis nos cartórios, mas também solicitarem a sua conversão em casamento civil, o que provocou uma onda de pedidos por todo o Brasil. A diversidade de decisões nos cartórios brasileiros obrigou o Conselho Nacional de Justiça (CNJ) a normatizar por resolução 
os procedimentos no cartório. A Resolução $\mathrm{n}^{\circ}$ 75, de 14 de maio de 2013, dispõe sobre a habilitação, celebração de casamento civil, ou de conversão de união estável em casamento, entre pessoas de mesmo sexo e vedou as autoridades competentes recusar pedidos de casamento civil entre pessoas do mesmo sexo.

Atualmente, as políticas LGBT do Estado brasileiro, em nível federal, são articuladas pela Coordenação Geral de Promoção dos Direitos LGBT, na Secretaria de Direitos Humanos. Ressalto a importância do Departamento de Apoio à Gestão Participativa (Dagep), do Ministério da Saúde, e da Secretaria de Educação Continuada, Alfabetização, Diversidade e Inclusão (Secadi), do Ministério da Educação, pelos programas e serviços de políticas públicas voltadas à população LGBT. O CNDC LGBT tem o importante papel de monitorar e propor políticas públicas, e já está em sua terceira composição de conselheiras e conselheiros.

Não obstante, as políticas LGBT, de gênero e para as mulheres, vem sofrendo um grande ataque dos setores fundamentalistas e conservadores, e que tem gerado impacto em sua formulação, implantação e manutenção, é notório que a resistência progressista não tem conseguido segurar plenamente os retrocessos impostos por estas forças, mas ainda assim há importantes avanços percebidos na execução das políticas nos estados e municípios que demonstra que as políticas LGBT tiveram capilaridade federativa desde a implementação do Brasil sem Homofobia.

\subsection{Marcos das Políticas para Mulheres Lésbicas e Bissexuais no Brasil}

A homossexualidade feminina é um tema que só muito recentemente iniciou sua entrada na agenda política brasileira. As ações são, em sua maioria, voltadas à saúde de lésbicas e mulheres bissexuais. Acontecem de forma incipiente e, em larga medida, realizadas de maneira descentralizada/desarticulada por organizações da sociedade civil. O próprio movimento de lésbicas, apesar de nascido no mesmo período em que o movimento gay no Brasil, permaneceu, até meados dos anos 1990, restrito a poucos grupos espalhados pelo país.

$\mathrm{Na}$ trajetória histórica que abrange os objetivos desta dissertação, algumas ações são marcos. Em 1996, a partir de demandas do movimento organizado, o Programa Nacional de DST/Aids criou o Grupo Matricial para discutir saúde de lésbicas, um marco para a produção dos primeiros encontros do movimento, materiais educativos, capacitações de lideranças e realização de pesquisas. Do apoio do PN-DST/Aids, surgiram também os Senale (Seminários Nacionais de Lésbicas), considerados propulsores da emergência e fortalecimento de lideranças em âmbito nacional. 
A criação da Secretaria Especial de Políticas para as Mulheres (SPM), em 2002, e todo o processo de construção do Plano Nacional de Políticas para as Mulheres (PNPM) incorporaram formalmente algumas demandas de mulheres lésbicas e bissexuais, no que diz respeito à saúde, à educação e ao combate à discriminação.

No âmbito do Programa Brasil Sem Homofobia (2004), das ações propostas que têm impacto sobre a questão das mulheres lésbicas e bissexuais, destaco: a realização de campanhas e implementação de centros de referência para o combate à homofobia; ações específicas para propiciar a inserção adequada das mulheres lésbicas no interior de políticas e equipamentos públicos de combate à violência contra a mulher, como as Delegacias Especializadas; promoção da atenção especial à saúde da mulher lésbica em todas as fases da vida, inclusive por meio da capacitação de profissionais de saúde; e formalização de espaços de interlocução entre o Ministério da Saúde e o movimento, como o Comitê Técnico Saúde da População de Gays, Lésbicas, Transgêneros e Bissexuais.

Em novembro de 2004 foi instituído, pela Área Técnica da Saúde da Mulher (ATSM), do Ministério da Saúde, um grupo de trabalho sobre a saúde da mulher lésbica, que contou com a participação de várias militantes do movimento social; que apresentaram consideráveis demandas, especialmente no que tange à prevenção de doenças e à saúde mental. Entre elas destacam-se: $i$ ) prevenção ao uso e abuso de drogas lícitas e ilícitas; ii) prevenção e tratamento à obesidade mórbida; iii) sensibilização com o Programa de Saúde da Família (PSF), para reconhecer o casal como família; iv) prevenção e tratamento para DST; v) prevenção e tratamento de câncer, especialmente de colo de útero e de mama; vi) presença da companheira no parto; e vii) prevenção e combate à violência entre casais de mulheres.

A articulação da Área Técnica de Saúde da Mulher, do Programa Nacional de Hepatites Virais e do Programa Nacional de DST/Aids propiciou a reativação do contato do movimento de lésbicas com o Ministério da Saúde no final de 2005. Na reunião que deu origem ao Projeto Chegou a Hora de Cuidar da Saúde, discutiu-se uma proposta de ampliação do acesso de lésbicas, bissexuais e outras mulheres que fazem sexo com mulheres, especialmente as de baixa renda e pouco acesso à informação, aos serviços de saúde. Essa proposta, de certo modo, foi ao encontro de outros itens elencados no PNPM, tais como a produção de manual técnico educativo que contemple, entre outras, as demandas das lésbicas e a capacitação de pessoal de atenção básica e serviços de referência.

A partir de então, várias reuniões aconteceram com articulação dos gestores do Programa Nacional de DST/Aids, Área Técnica de Saúde da Mulher do Ministério da Saúde e Programa Nacional de Hepatites Virais. Como um dos produtos da reunião realizada em 
dezembro de 2005, o estado de São Paulo foi escolhido como um das regiões para a realização do Piloto. Em São Paulo, essa proposta encontrou suporte no Programa Estadual de DST/Aids, que tem priorizado, desde 1999, as ações com a população LGBT a partir da criação do Fórum Homens que fazem sexo com Homens (HSH), que em 2003 passou a se chamar Comitê Técnico da Diversidade e a contar com uma participação significativa de mulheres lésbicas e bissexuais. Nesse sentido, a proposta do Piloto foi ao encontro das demandas dessas mulheres por ações que pudessem melhorar o acesso e a qualidade da atenção à saúde de lésbicas e mulheres bissexuais.

Outra ação importante realizada a partir da parceria entre a Área Técnica de Saúde da Mulher, o Programa Nacional de Hepatites Virais e o Programa Nacional de DST/Aids, foi a elaboração da cartilha Chegou a hora de cuidar da saúde sobre saúde das mulheres lésbicas e bissexuais, cuja elaboração contou com a participação do movimento social e da academia, e o lançamento, em São Paulo, deu-se durante as celebrações do Mês do Orgulho LGBT de 2006.

No ano de 2007, o Ministério da Saúde publica o Plano Integrado de Enfrentamento da Feminização da Epidemia de Aids e outras DST, cuja construção foi acompanhada por mulheres lésbicas e bissexuais representando movimentos sociais. Desse Plano, vale destacar uma das diretrizes: "Promover a equidade racial, étnica, de gênero e de orientação sexual das mulheres no acesso a informação, diagnóstico e tratamento". A atuação do Plano deveria ser na direção de promover equidade por meio de ações que sensibilizem quanto a: violações de direitos no âmbito dos serviços; garantia do sigilo quanto a informações relacionadas à saúde e à orientação sexual; e para a necessidade de incluir a investigação e registro do quesito orientação sexual em fichas de atendimento e/ou roteiro de anamnese.

Atualmente, as políticas públicas para mulheres lésbicas e bissexuais continuam voltadas à área da saúde, em sua maioria. A representação das mulheres lésbicas e bissexuais em nível do Executivo federal é nos espaços LGBT citados anteriormente. 


\section{CAPÍTULO 3 \\ VOZES LÉSBICAS}

Neste capítulo, minhas recordações são o ponto de partida das lutas que travei no movimento social, das histórias vividas, das muitas atividades desenvolvidas com companheiras valorosas.

Há inúmeras versões da história do movimento de lésbicas no Brasil. Essas muitas versões se dão pelas diferentes perspectivas que diversas ativistas, muitas ainda em atividade, têm sobre os fatos e suas ações ao longo dos mais desses 37 anos de história.

A história que se organiza neste escrito são as vozes que conheci e com as quais convivi em meus anos de ativismo, que muitas delas me contaram pelas suas percepções, também a minha história que, de forma indireta, pelas vozes lésbicas, ${ }^{12}$ será contada.

Poucas são as dissertações, teses, artigos e estudos sobre o movimento de lésbicas, e isso reforça a minha hipótese de que o movimento de lésbicas no Brasil tem sua história mal contada, o que talvez se deva à mistura de amores e desamores, política e ativismo, que, ao longo de sua construção histórica, tem marcado o movimento com rupturas políticas que levaram a rupturas amorosas e rupturas amorosas que levaram a rupturas políticas.

A história da lesbianidade, assim como sua vivência, é uma história clandestina, ignorada e marcada por invisibilidades, contradições e discordâncias entre as historiadoras que assumiram a tarefa de recuperar seus fragmentos.

Para Monique Wittig (1992), lésbica é um conceito que transgride a categoria mulher, pois é estado relacional ao gênero oposto, o homem e sob o heterossexismo, pressuposto da heterossexualidade compulsória. Wittig (1992) e Beauvoir (1949) rompem com a lógica natural que compreende e define as mulheres pela perspectiva biológica, inata e imutável.

A partir da provocação das autoras Wittig e Beauvoir "Ninguém nasce Mulher" se percebe o quanto complexas são as análises teóricas em torno da pessoa lésbica, que menciono desta forma, pois, na tentativa de definir a mulher lésbica, surge o questionamento sobre a definição de quem é a mulher.

Wittig (1992) ainda dialoga sobre a necessidade de destruir o conceito "mulher" que não consiste na destruição física da mulher ou, ainda, não significa destruir a lesbianidade

12 Ao referir o texto Vozes Lésbicas, certamente estou me referindo àquelas que entrevistei de forma direta ou indireta, além das minhas memórias que, em todo o texto, estão refletidas. 
simultaneamente com as categorias de sexo. Segundo a autora, a lesbianidade oferece, de início, a única forma social na qual podemos viver livremente.

Ainda analisando a estrutura dos conceitos mulher e lésbica, Wittig (1992) se refere à lésbica como o único conceito que está mais além das categorias de sexo (mulher e homem), pois o sujeito lésbica não é uma mulher, nem economicamente, nem politicamente, nem ideologicamente. Pois o que faz uma mulher é uma relação social específica com um homem, uma relação de servidão, uma obrigação pessoal, física e também econômica imbricada ao homem, ainda que de fato não haja relação, uma relação à qual as lésbicas escapam quando rejeitam tornar-se o seguir sendo heterossexuais.

Entender a busca pelo reconhecimento da cidadania me obriga a observar as intersecções, a hierarquia das opressões, a (in)visibilidade lésbica nos direitos das mulheres, o movimento LGBT seu comportamento e a percepção e (não) importância da categoria cidadania pelas mulheres lésbicas, assim como suas versões da história.

A experiência deste manuscrito me fez entender que assumir esta tarefa é assumir um lado, e neste caso, é o lado da minha vivência, não no sentido strictu sensu, mas no latu sensu, na orientação de dar voz aos sentidos que senti ao conviver ao longo da minha trajetória com essas mulheres que, para o todo, algumas tiveram muita ou pouca relevância, mas que para minha história e lutas foram parceiras, companheiras, protagonistas, coadjuvantes ou, ainda, existiram e se fizeram perceber e, por isso, fez sentido ouvi-las.

Não foi uma tarefa fácil identificar as entrevistadas, convencê-las e, por fim, ter suas vozes disponíveis para este trabalho. São várias as razões a que atribuo isso, uma delas, e que considero relevante, é o fato de que, como personagem desta história, imagino que existiu um sentimento de não confortabilidade para algumas delas permitirem-se serem ouvidas por mim, alguém que, de igual maneira, está lado a lado nessa história, em avanços e embates políticos pelos caminhos que percorri.

As escolhas que tive ao longo da minha trajetória no ativismo, com certeza, contribuem para o meu olhar impresso neste trabalho, e também para a visão que as entrevistadas têm sobre minhas escolhas e a influência em se permitirem refletir e ouvir neste texto, desde as contatadas, as confirmadas e as que, por fim, aceitaram contribuir com esta reflexão que prefiro acreditar ser coletiva, na medida em que parte da minha memória é influenciada por muitas vozes e contribuições que me fizeram chegar aqui.

Desde o início, sabia que encontraria esses obstáculos e, por isso, busquei outras maneiras de ter as vozes que mapeei refletidas neste texto, as escolhas não foram aleatórias, e 
as técnicas que são abordadas na metodologia, propiciaram que, de forma direta ou indireta, suas vozes estejam presentes.

Para a confecção das histórias e das vozes aqui transcritas, busquei entrevistar dez ativistas. Três entrevistas foram realizadas e as demais, mesmo com sucessivos contatos e algumas confirmações, ao fim não obtive retorno. As ativistas lésbicas entrevistadas possuem trajetória de vida e de ativismo dentro do período compreendido no objeto deste trabalho, mesmo que, de alguma maneira ou em algum momento de seu ativismo, tenha havido expressão nacional e, ainda, expressão à diversidade dentro do movimento de lésbicas, seja pelo seu envolvimento desde o início do movimento, seja pelas intersecções de raça e etnia.

Ainda, como forma de obter uma expressão maior das vozes, busquei acessar demais ativistas pelas suas citações públicas em textos, publicações ou participações em seminários que estou metodologicamente chamando de entrevista indireta.

Nesse sentido, entendo que a profundidade da entrevista não se dará de igual maneira como das gravadas, mas, ainda assim, considero importante registrar sua memória e sua voz, inclusive pela sua importância na história do movimento de lésbicas.

E ainda, complementando os fatos e as histórias que serão narradas a seguir, permitirei me entrevistar, pois também sou parte desta história, ora como coadjuvante, ora protagonista e muitas vezes como expectadora e beneficiária dos avanços obtidos pela luta e história destas guerreiras mulheres.

Para as entrevistas, foi utilizada a técnica em profundidade para coleta de dados, pelo fato de esta valorizar a presença do investigador e oferecer todas as perspectivas possíveis para que o entrevistado tenha a espontaneidade necessária. Na formulação do roteiro de entrevistas, seguiram-se as indicações de Parker, Herdt e Carballo (1995, p. 36-37) para entrevistas em uma perspectiva etnográfica.

Ao planejar o cronograma das entrevistas profundas, no entanto, o método mais produtivo é tentar desenvolver um formato semiestruturado que possa ser reproduzido, pelo menos em suas linhas mais gerais, com todos os informantes a serem entrevistados em uma determinada população. Devem-se fazer perguntas abertas sobre tópicos relevantes, seguindo um esboço ou lista de tópicos gerais que permita que um tópico naturalmente conduza a outro. Estes autores também enfatizam que as informações pessoais "[...] da infância até a atualidade, incluindo suas experiências sexuais aprovadas e desaprovadas e seus efeitos emocionais e sociais, devem ser um elemento chave na agenda de pesquisas para entrevistas profundas" (PARKER; HERDT; CARBALLO, 1995, p. 37). 
Nesta pesquisa, as entrevistas em profundidade seguiram um roteiro semiestruturado composto a partir de três blocos: $i$ ) Trajetória de vida; ii) Trajetória do ativismo; iii) Trajetória da cidadania LGBT no Brasil, as quais foram audiogravadas, depois transcritas, e uma das entrevistas foi realizada por escrito. A partir desse material, foi possível realizar uma análise discursiva das ativistas e dos fatos por elas narrados a fim de compreender os principais contextos da história do movimento de lésbicas no Brasil e seus impactos na conformação do movimento nas suas sucessivas etapas e identificação dos percursos percorridos pelo movimento social na construção da cidadania LGBT por meio das vozes aqui entrevistadas.

\subsection{Agora é que são elas}

Nesta pequena introdução, antes de apresentá-las, relato algumas experiências interessantes com as ativistas entrevistadas diretamente. Durante a entrevista com a Yáskara, ela citou sua amizade e vivência com a Cassandra Rios, o que reforçou minha perspectiva de incluí-la, dando voz e sentido ao seu ativismo. Outro fato que destaco é a diversidade que as três entrevistas representam: Marisa, descendente de imigrantes refugiados da Europa devido à guerra, operários radicados no ABC Paulista; Heliana, filha de negros de classe média, sobrenome famoso nos anais da história negra carioca, e Yáskara, filha de ciganos imigrantes do Oriente e muçulmanos.

Buscando em minha memória as influências lésbicas em minha vida, começo essa história com Cassandra Rios, pseudônimo de Odete Rios. Nascida em 1932, assumiu-se Cassandra em 1948, vivia em São Paulo e foi a primeira escritora a escrever sobre lesbianidade, desejos, prazeres e o ser lésbica. Cassandra Rios, certamente, em minha memória, marca os antecedentes das vozes lésbicas no Brasil.

Cassandra Rios surge para o Brasil com o livro A volúpia do Pecado. Seus livros ousavam abordar questões acerca da sexualidade considerada normal ou desviada, e isso lhe trouxe um sucesso editorial, ainda que na marginalidade intelectual, mas que fez dela a Cassandra, uma escritora com produção literária com cerca de 50 livros, cada um com mais de dez edições, sendo a primeira escritora brasileira a atingir a marca de um milhão de exemplares vendidos. Sua primeira publicação foi aos 16 anos, e ela chegou a ser uma das escritoras mais censuradas do país, principalmente no período da ditadura (REIMÃO, 2011).

Foi nessa época que Cassandra conheceu Yáskara, que a abrigou com outros jovens perseguidos, que pichavam de batom expressando-se contra a ditadura, quando a polícia 
fechou as galerias na cidade de São Paulo. Esses foram anos de chumbo, tenebrosos e de muita perseguição política. E foi nesse dia tenebroso que Cassandra abriu sua livraria na galeria para que os jovens se escondessem, o que acentuou ainda mais sua perseguição.

Cassandra era uma pessoa assim estranha, porque, na verdade, ela era duas pessoas ao mesmo tempo, ela era Odete, e como Odete ela era religiosa, recatada, aquela coisa toda, mas ela era também Cassandra. Ela sofria muito, muito mesmo e, no auge do sofrimento, ela resolveu combinar com um gay e casar com ele, para ela poder ter um pouco de liberdade, foi um casamento de arranjo. Era um gay amigo e, no final da festa, o gay com o namorado dele, foi um casamento mesmo só de arranjo para tampar o sol com a peneira, porque naquela época era terrível, terrível, não podia. Odete era lésbica, mas não gostava de falar a respeito, mas Cassandra sim, esta gostava, era terrível, nas festas era terrível (risos) e ousada, aqueles livros (suspiros) todo mundo criticava, mas lia, ela mal lançava um livro e ele se esgotava.

Quando relatava sua história de ativismo, Yáskara se lembra de mais algumas passagens de sua vida ao lado de Cassandra, que morreu de câncer em 2002.

Uma coisa de que me esqueci: eu fiquei muitos anos sem ver Cassandra, eu não sabia onde ela morava, eu não sabia mais nada, nada da Cassandra, muitos anos sem vê-la, morria de vontade de reencontrá-la. Cassandra Rios era muito interessante, muito engraçada também. E que quando era jornalista na G Magazine, me disseram que alguém poderia entrevistar Cassandra e eu conhecia tanto de Cassandra, dos anos de chumbo, de repressão, e conseguimos localizá-la e eu fiz a última entrevista, a entrevista está na revista $G$ Magazine e, enfim, nos reencontramos, mas aí a Cassandra não estava muito bem, estava com câncer, não demorou muito tempo e ela faleceu. A última fotografia que ela tirou foi um mês antes dela morrer, ela estava mal, mal, mal, ela queria comer frutos do mar, num restaurante perto da Avenida Paulista, e lá tiramos algumas fotos, ela já tava bem abatida, já sabia que ia morrer, ela sabia. Outra coisa que me aborreço profundamente sempre eu penso nisso, Cassandra escreveu uma espécie de biografia, Flores e Cassis, e ela cita ali uma porção de pessoas importantes, até pessoas que ela mantinha relacionamento, tatatá, mas Cassandra morreu muito pobre, sem ninguém, todo mundo virou as costas, a única pessoa que não virou as costas foi Luiza Erundina, e quando ela estava muito mal, a gente cuidando dela e ela já nem saía mais da cama, ela morava do lado da Santa Casa, nós nos revezávamos para cuidar dela e quando eu vi que a gente não dava mais conta, pois as dores eram fortes, aí eu peguei o caderninho dela e vi lá Luiza Erundina, aí eu liguei, a M. que atendeu, eu expliquei a situação, ela voltou e disse: "arruma tudo que em dez minutos uma ambulância vai passar aí", então ela teve uma morte digna dentro do hospital, graças a Erundina, os outros todos citados no livro, famosos, ninguém quis saber.

Certamente, nesses anos de chumbo, as marcas da repressão e da imposição de um Estado ditatorial militar, opressivo, violento e profundamente moralista, as vozes que neste trabalho se expressam descobriam seus desejos, corpos, paixões e amores. 
Marisa para as mais jovens no movimento, Fernandes para as contemporâneas, nasceu em 1953, em Santo André, no ABC paulista. Estudou em escola pública, formou-se em História pela USP, quando conheceu o movimento estudantil e o então movimento homossexual brasileiro, onde também fez mestrado em Teoria de Gênero na Historia Social. Professora da rede pública, é aposentada e vive atualmente sozinha em São Bernardo do Campo. Marisa Fernandes vivenciou profundamente o período ditatorial e foi nele que se forjou mulher, lésbica e feminista:

Primeiro é necessário considerar que atualmente estou com 62 anos de idade; que minha origem de classe social é de filha de operários do $\mathrm{ABC}$ paulista, oriundos de imigração europeia, como refugiados de guerra e pobreza; que meus pais não tiveram acesso à educação formal/escolar, ou seja, tiveram baixíssima escolaridade. Feitas estas importantes considerações, ainda é preciso destacar que como toda manifestação da sexualidade/do desejo se acentua mais durante a fase da adolescência, então, a partir dos meus 12 anos de idade, o ano era o de 1965, o regime político da Ditadura Militar, por meio de um Golpe de Estado já estava vigente há 1 ano. Golpe apoiado por forças extremamente conservadoras, não apenas no campo político partidário, mas também pelas forças que clamavam pela defesa da moral, da família, dos bons costumes, por Deus e pela família. Não havia divórcio e as mulheres separadas ou "largadas pelo marido" eram consideradas perigosas para as famílias, pois destas seriam as desagregadoras.

A descoberta de sua sexualidade, como era ser lésbica naquela época e, ainda, sobre sociabilidade e apoio familiar, Marisa reforça em seus diálogos as questões vivenciadas à época, como a repressão militar, os valores da família, que reforçavam e legitimaram o golpe militar, a origem pobre de refugiados de sua família e as construções, ainda que silenciosas, o apoio familiar à medida que as relações se enfraqueceram pelo medo de perder a filha.

Minha mãe, que teve quatro filhas mulheres, assim como todas as outras mães, entendia que a "maior vergonha" para uma família era uma filha engravidar, ainda solteira. As mães solteiras também eram muito malvistas, geralmente expulsas das suas casas, para que a "honra" daquela família fosse mantida perante as outras. Neste cenário então fui educada a jamais fazer sexo antes do meu casamento e minha sexualidade começou a partir deste referencial - impedir uma gravidez - a ser altamente reprimida, sempre por fortes ameaças, exemplo: expulsão e abandono da família pela vergonha. Eu seria considerada, caso engravidasse, uma sem-vergonha e jamais seria escolhida para casar, ou seja, o destino da minha vida estava traçado e marcado por algo que só me traria desgraças. Minha mãe demorou tanto para me dar o primeiro soutien/sutiã e quando o fez comprou um que era sem bojo, tudo no intuito de não me tornar sensual ou desejável. Eu cortava os bojos de algum sutiã que encontrava jogado, velho, e colocava no lugar do meu sutiã sem o bojo. Jamais fui informada como era o processo ou como se dava o famoso, à época, "ficar mocinha", ou seja, menstruar. Eu morria de curiosidade, pois minhas três irmãs, mais velhas do que eu, já eram 
"mocinhas", mas ninguém me falava o que acontecia, apenas eu ouvia dizer que a partir daí era muito perigoso, mas eu não sabia qual era o perigo. Apenas temia, mas tinha curiosidade. Uma irmã minha, cruelmente me falou que os dedos das mãos ficavam compridos. Eu nunca havia visto uma mulher adulta nua, logo, desconhecia o surgimento de pelos pubianos. Neste cenário de que tudo me foi calado, não dito, não ensinado, não revelado, fui enfrentando o meu processo de crescimento dentro da maior ignorância possível e, claro, com a maior curiosidade. Por muito tempo culpei minha mãe por ela não ter ensinado suas filhas mulheres a se preparar e saber como agir, como se cuidar, o que fazer para se proteger. Logicamente mais tarde pude compreendê-la, quando consegui situá-la dentro do próprio cenário em que ela vivia. A pílula anticoncepcional só começou a ser comercializada no Brasil, em 1962, não sei agora precisar se havia acesso para todas as classes sociais, mas certamente não, de qualquer forma eu fui a última filha e nasci em 1953, ou seja, todas as relações sexuais da minha mãe, para evitar gravidez, eram feitas com coito interrompido, sempre me perguntei se alguma vez minha mãe havia tido um orgasmo. Ela sempre falava que não gostava de sexo, fazia por obrigação. Ela nunca foi criada por uma mãe. Enfim, jamais teve culpa de ignorar como falar de sexo com filhas meninas, em uma época que ninguém falava de sexo com seus filhos, pelo menos com as filhas. Meu primeiro beijo de língua foi heterossexual, aos 13 anos de idade, em 1966, e daí para frente apenas deixava que os garotos me tocassem com os seus dedos por dentro da minha calcinha. Pinto, jamais os via, nem queria saber, e se eu engravidasse? [...] Em 1968, com 15 anos de idade, eu estava na sétima série do que naquele tempo era chamado curso ginasial. $\mathrm{Na}$ minha sala de aula entrou uma garota mais jovem do que eu 1 ano, então ela, com 14 anos de idade, descobrimos que morávamos no mesmo bairro, muito, muito próximas, então nos aproximamos desde a ida e a volta da escola para casa, bem como no "recreio" e na sala de aula. Então nos apaixonamos, sem saber que nome tinha o que passamos a ser, sem saber como a sociedade encarava uma situação como aquela. Sabíamos apenas que o amor era lindo, que nos gostávamos e que estávamos felizes naquele momento inicial e voltávamos da escola de mãos dadas e também nos beijávamos no portão quando íamos cada uma para dentro da sua casa. Descobrimos ao mesmo tempo o amor, a proibição, a violência doméstica, os impedimentos, a expulsão da escola e muita perseguição por parte da família. Estudamos juntas a sétima e oitava séries, 1968 e 1969, na oitava série as minhas notas de rendimento escolar caíram em relação ao ano anterior.

Nascida no Rio de Janeiro, em 1954, dez anos antes do golpe de 1964, Miriam Martinho ${ }^{13}$ cresceu em São Paulo, morou em Santo André. Ativista lésbica, precursora do movimento, formou-se em Letras pela USP, e em tradução pela Associação Alumni. Miriam é budista e atualmente é editora-chefe de blogs. A construção de sua sexualidade e o ativismo se deu nesse período de repressão:

Entrei na adolescência quando do início do regime militar que se estendeu por 21 anos. Não tenho memória do período pré e imediatamente pósdeposição do Jango, porque só tinha dez anos. Dos anos seguintes, já me lembro melhor: foram os anos dos festivais e dos programas da TV Record.

13 Entrevista extraída do site, acesso em: 18 jan. 2016. 
[...] Os tropicalistas Gal, Caetano, Gil, os Mutantes etc., foram os que realmente fizeram minha cabeça, o disco Panis et Circencis (1968) rodando na vitrola sem parar. Mas também me emocionei com Pra não dizer que não falei de flores (1968), do Vandré, muito pobre esteticamente se comparada à canção Sabiá, de Chico Buarque e Tom Jobim, mas um hino de época contra o regime autoritário. [...] Com o Ato Institucional 5 (AI-5-13/12/1968), os militares escancararam sua ditadura, fechando o Congresso, censurando a imprensa e a cultura, restringindo os direitos civis, reprimindo desde os que a ela se opunham abertamente até a quem era apenas suspeito do que chamavam de subversão. E, naquela mistura de rigidez militar e conservadorismo moral que caracterizou os chamados anos de chumbo, subversivos podiam ser desde os guerrilheiros do Araguaia até a barriga grávida da Leila Diniz exposta nas praias do Rio. Não deixa de ser curioso observar, contudo, que, apesar do clima antissubversivo, muito da grande revolução de costumes que rolava no exterior conseguiu aparecer por aqui. A versão brasileira da peça Hair (1969 a 1972) trazia o hippismo aos tupiniquins, terminando com os atores nus no palco, e a androginia dava as caras com os bailarinos do Dzi Croquettes (1972-73) e os cantores e compositores dos Secos e Molhados (1973-74). Assisti a todos em teatros de Sampa. Fora naturalmente todo o pacote da contracultura, filha do anarquismo pacifista, com sua mistura de drogas, amor livre e rock'n'roll, que chegava via discos dos festivais de Woodstock (1969), Altamont (1969), Ilha de Wight (1970), os Beatles e os Rollings Stones, David Bowie, Janis Joplin, Jimmi Hendrix, Jim Morrison (pra citar alguns) e a coluna Underground do Pasquim. Sem esquecer também os icônicos shows de Gal Costa (Fatal, 1971) e Maria Bethânia (Rosa dos Ventos, 1971), com Gal incorporando a musa libertária tropicalista por boa parte da década de 1970 . Todos também rolando em minha vitrola sem parar. No bojo da contracultura e da revolução sexual, igualmente vieram as mudanças no papel da mulher e a saída do armário da homossexualidade, culminando, no fim dos anos 70, com o surgimento das primeiras organizações feministas (segunda onda) e homossexuais brasileiras. Ainda foi aprovada a lei do divórcio, em 1977, não sem os protestos dos grupos conservadores que tomaram as ruas pra entoar seu eterno mantra da defesa da família.

Rosely Roth, branca, judia e lésbica feminista, como é citada pela maioria das ativistas, nasceu em 1959, em São Paulo. Cursou Filosofia na Pontifícia Universidade Católica (PUC/SP), em 1981, e concluiu a pós-graduação em antropologia em 1986, com estudos em gênero e lesbianidade. Rosely Roth se suicidou em 28 de agosto de 1990.

Falar do movimento de lésbicas é falar de Rosely, da sua força, sua garra e seu envolvimento em prol dos direitos de lésbicas no país. Não foi fácil buscar informações sobre a vida da Rosely, mas traduzo abaixo nas palavras de Miriam Martinho ${ }^{14}$ o que Rosely representou para todas nós e para as gerações futuras.

Iniciou seu contato com o movimento de mulheres, no primeiro semestre de 1981, quando começou a participar simultaneamente dos

14 Disponível em: 〈http://www.umoutroolhar.com.br/2012/08/tributo-rosely-roth-e-livreto-dia-do.html\#more〉. Acesso em: 15 mar.2016, às 21h40. Na seção tributo a Rosely Roth feito por Miriam Martinho. 
grupos Lésbico-Feminista/LF (1979-1981) e SOS Mulher(19801983). Em outubro de 1981 fundamos o Grupo Ação Lésbica Feminista, GALF (1981-1990), um grupo a princípio de continuidade do grupo lésbico-feminista, cujo coletivo original se dispersara, mas que viria, no decorrer de sua existência, a desenvolver características próprias tanto em termos políticos quanto em suas atividades.

A partir de 1982, deixou de atuar no coletivo SOS Mulher, vindo a dedicar-se exclusivamente ao Grupo Ação Lésbica-Feminista (GALF) do qual foi figura de destaque seja por seus artigos, nas duas publicações da entidade - os boletins ChanacomChana (12/82 a 05/87) e Um Outro Olhar (12/87 a 1995) - e pela organização de debates, com outros grupos dos Movimentos Feminista, Homossexual e Negro, além de com parlamentares da época, seja por sua participação em atividades externas (manifestações, encontros, simpósios, congressos) ou por sua presença constante, publicamente lésbica, na mídia brasileira. Entre as inúmeras atividades que realizou, por seu impacto político, destacam-se: 1) a organização de uma manifestação de protesto (19/08/83), junto aos proprietários do Ferro's Bar (o mais antigo e tradicional bar lésbico do Brasil) que não permitiam a venda do boletim ChanacomChana em seu recinto, apesar de este ser sustentado fundamentalmente por lésbicas, e que reuniu ativistas do movimento homossexual e feminista, parlamentares e representantes da $\mathrm{OAB}$, com bastante destaque na mídia, e 2) duas participações (25/05/85-20/04/86) em programas da apresentadora Hebe Camargo (uma das mais populares do Brasil), em cadeia nacional, falando de forma aberta e tranquila sobre lesbianidade, com grande repercussão na imprensa e junto à própria comunidade lésbica e gay.

Rosely Roth foi pioneira no que se convencionou chamar de "política da visibilidade" em uma época (década de 80) em que, com raras exceções, ninguém mais o fazia, aliando aparições públicas, geralmente marcantes e com fundamentação teórica.

Márcia Yáskara Guelpa, conhecida como Yáskara, mora em São Paulo, tem 75 anos, é ativista lésbica, cigana da etnia romani, muçulmana e avó. Formada pela USP em Letras e Pedagogia, fez pós-graduação também pela USP em História da Educação e Teoria Literária. Trabalhou durante anos nos seguintes veículos de comunicação: Revistas Manchete, Vogue, Isto É, Nova, GMagazine, dentre outras, e no Jornal da República, do Mino Carta. Representou o povo cigano na Comissão Nacional de Povos e Comunidades Tradicionais, vinculada ao Ministério do Meio Ambiente da sua criação até 2010.

Eu tenho uma história bonita que nunca contei para ninguém, acho que contei para a Marisa Fernandes, acho, não tenho certeza. Eu nasci na verdade em 1940, fora, meu pai mudou o nome [...] veio ao Brasil em 1941, aí me registrou aqui como se eu tivesse nascido no Brasil, tendo eu nascido em 1941 - na minha carteira de identidade eu nasci em 41, na verdade eu nasci um ano e pouco antes. Meu pai era um homem, não era analfabeto, mas ele era um homem que nunca estudou, era um homem interessante, e quando eu era criança, eu tinha uns 10, 11 anos mais ou menos, e eu ganhei uma foto da 
Marlene Dietrich no Anjo Azul. ${ }^{15}$ E eu me apaixonei pela Marlene Dietrich, eu achei linda aquela foto, naquela época a gente era muito pobre ainda, nós não morávamos em tenda, mas onde eu dormia era tenda, mas eu coloquei na parede e meu pai falou "olha que bonita, quem te deu?" e eu falei "foi uns vizinhos aí e tal”, e perguntei pro meu pai: “- Papai é muito longe Hollywood? Eu gostaria de ir pra lá". E ele me disse: "Por que, você quer ser atriz?" "Eu não, é que eu vou crescer e vou casar com ela". Papai ficou meio assim, mas não falou nada, no dia seguinte voltou para me desejar boa noite e falou: "como foi mesmo essa história, você quer casar com a atriz? Ela é uma moça, uma senhora, você uma menina, e mulher não casa com mulher", e eu insisti que não queria saber, eu queria casar com a Marlene Dietrich. [...] Aí papai falou para meu avô "ela vai estudar". Papai fez campanha para o Ademar de Barros e ele queria dar um presente para o papai, e então ele pediu uma vaga na Caetano de Campos para mim. Eu entrei na escola Caetano de Campos, com 17 a18 anos e eu saí normalista, eu pulei alguns anos porque eles me ensinaram em casa. [...] Em casa meu pai falava algumas línguas, eles me ensinaram algumas, eu falava russo. [...] Só não morei em São Paulo, quando saí fora do Brasil [...] É tão simples, mulher que se apaixona por mulher, é o que lésbica, é uma coisa tão simples, tão natural não sei por que fazem isso tudo, quando eu era criança eu nem percebia, mas meu pai soube antes, meu pai era muito [...]. Eu me achava um etezinho, eu tinha vergonha de pensar em gostar de uma mulher, eu achava aquilo, assim, terrível, mas depois de algum tempo eu conheci Cassandra Rios, conheci algumas pessoas e aí eu fui me moldando à situação, mas era uma época tenebrosa, nós não tínhamos a mínima liberdade de dizer o que a gente sentia.

Carmen Lucia Luiz, ${ }^{16} 65$ anos, mora em Santa Catarina, na capital Florianópolis, é enfermeira sanitarista e atuante na rede pública de saúde. Possui especialização em Psiquiatria Social pela Escola Nacional de Saúde Pública, e especializações em Saúde Pública pela UFSC/Fiocruz. Foi conselheira nacional de saúde pela Liga Brasileira de Lésbicas, rede de lésbicas fundada no Planeta Arco-Íris ${ }^{17}$ do Fórum Social Mundial em 2003. Carmen é filha de uma família de oito filhos, cinco mulheres e três homens. Carmen é a menina entre dois irmãos.

15 Filme em que a atriz Marlene Dietrich atuou em 1930, em que ela representava uma sensual cantora de Cabaré.

16 Carmen, Eide e Verônica (que seguem abaixo) tiveram seu depoimento realizado no III Seminário de Memórias e Visibilidades de Lésbicas e Mulheres Bissexuais, ocorrido no Museu Histórico de Santa Catarina - Palácio Cruz e Souza, em Florianópolis/SC, de 19 e 20 de agosto de 2015.

17 Planeta Arco-íris foi um espaço idealizado pelo movimento LGBT dentro do Fórum Social Mundial, localizado na Usina do Gasômetro em sua $3^{\circ}$ edição realizada em Porto Alegre de 23 a 28 de janeiro de 2003. A tenda era uma forma de persuadir a organização em incluir a representação do movimento LGBT no conselho internacional do FSM e a perspectiva de a temática de direitos humanos passa pela questão da construção da sexualidade. O Manifesto Sem Homofobia: um outro mundo é possível. Disponível em: <http://www.umoutroolhar.com.br/2012/08/tributo-rosely-roth-e-livreto-dia-do.html\#more>. Acesso em: 27 mar. 2016, às $20 \mathrm{~h} 30$. 
Embora me reconheça lésbica, esta história é engraçada, já contei isso outras vezes. É engraçado em parte. Mas, quando eu tinha oito anos de idade, eu sou a do meio de dois meninos. Então, eram meus companheiros de brincadeira, eram esses dois irmãos né, que as outras irmãs já eram bastante mais velhas, e a minha irmã mais jovem que eu tenho hoje ainda não existia ou era muito bebê. Então, eu brincava com esses dois meninos, um irmão mais velho e um irmão mais moço. E a minha farra era toda deles, era brincar na rua, era andar de patinete, era o que eles faziam eu queria fazer, meus companheiros. E um dia nós estávamos roubando goiaba de uma vizinha, assim, a gente subiu no muro, eu e meus dois irmãos e mais uma galera da rua, todo mundo roubando goiaba, e eram todos meninos, amigos dos meus irmãos, portanto meus amigos também, porque eu fazia parte daquela turma. $\mathrm{E}$ a dona da casa deu um flagrante na gente, correu com todo mundo daquele lugar, e ela gritava pra mim: "- Sua machorrinha, o que que tá fazendo aqui, sua machorra?!”. Me chamava de machorra! Eu não conhecia essa palavra, eu tinha oito anos, eu não tinha a mínima ideia do que era isso e do que ela tava me chamando. E eu cheguei em casa e falei, contei pra minha mãe, por que a mulher me chamou daquela coisa, eu senti que era uma xingação, porque o tom de voz dela era odiento, ela estava brigando comigo. E eu cheguei em casa toda dolorida e disse pra minha mãe: “- Mãe, a gente tava só pegando goiaba e ela brigou comigo e ela me chamava de machorra mãe, o que é isso?". E a minha mãe diz: “- Cala esta boca, menina! Vai brincar lá fora! E me botou pra fora de casa". E eu não soube o que era essa palavra até muitos anos. E eu me esqueci disso também, nem lembrava mais desse negócio, me esqueci.

Heliana Hemetério dos Santos, lésbica, feminista e negra, nasceu no Rio de Janeiro, em 1951. Heliana Hemetério, como é chamada pelas amigas no movimento de lésbicas, atualmente mora em Curitiba, reside com seus dois filhos e com sua companheira também ativista lésbica negra, aos fins de semana. Heliana é graduada em História, especializou-se em História da África em Gênero, Pós-Graduação em Gênero, Raça e Sexualidade, Sociologia Urbana e "Sankofa" Identidades Negras e Mulheres, Lugares da Casa e do Corpo e pesquisadora aposentada do IBGE.

Sempre possuí uma grande admiração por mulheres que considerava bonitas e, particularmente, por seios. Não tinha noção do que significava aquilo, porém desejava beijá-las e pegar nos seios. Pensava que gostaria de experimentar um dia. Embora percebesse que minha sexualidade fosse diferente, pois, durante um bom tempo, homens e mulheres me atraíram, eu não conhecia nenhuma outra mulher que vivenciasse isso. [...] Nunca abri esse diálogo com minha família, embora tanto meu pai quanto minha mãe percebessem minha mudança de relação (de homens para mulheres), não falaram nada. Nunca tocaram no assunto, porém nunca fizeram críticas e nem disseram nada quando saí de casa para morar com Ana Teresa minha primeira companheira.

Após a morte dela, tive outras, e o comportamento deles continuou o mesmo. O mesmo aconteceu com o resto da família. Embora não digam nada abertamente, quando convidam estendem "à amiga" e agora aos filhos. [...] 
No final da década de 1970 , não existiam redes de sociabilidade. Não tinha com quem conversar, não havia espelhos e exemplos. O Jornal Lampião possuía uma coluna em que gays e lésbicas tentavam formar uma relação amorosa. Para mim era muito complicado acessar esse tipo de contato. Eu sempre preferi conhecer pessoas pessoalmente, até porque havia um certo receio desse convívio.

Neusa das Dores Pereira, feminista, negra e lésbica, é conhecida no movimento como Neusa das Dores. É professora, empreendedora social pela Ashoka. Atualmente diretora executiva da ONG Coisa de Mulher. Nasceu no Rio de Janeiro, onde mora atualmente, sendo condecorada com o título de Benemérito do estado do Rio de Janeiro pela Assembleia Legislativa do Rio de Janeiro, e foi homenageada com a moção Negras Guerreiras, oferecida pela Câmara de Vereadores no Rio de Janeiro.

Dentre as muitas das marcas da história de vida da Neusa, a intersecção entre gênero, sexualidade e raça é marca da militância de Neusa que traz na em sua luta por igualdade de direitos e no enfrentamento ao racismo, a sua voz e sua força de mulher negra que ecoa no questionamento abaixo.

Engraçado, eu me tenho feito muito essa pergunta ultimamente. Hoje, eu acho que a presença da minha mãe está muito forte nessa história. Minha mãe tinha uma preocupação muito grande, embora semianalfabeta, com a comunidade onde ela estava inserida. Eu morava num subúrbio da cidade do Rio de Janeiro e ela era uma das "donas" do morro. Na comunidade negra, esse título tem um significado muito próprio. Ser uma dona/tia é muito importante dentro da comunidade, isso as diferenciam de uma mulher qualquer. Embora jovem, ela era extremamente respeitada na comunidade. $\mathrm{Na}$ minha casa, ficavam mulheres que os maridos brigavam, espancavam, botavam para fora de casa, ela recolhia essas mulheres, as crianças e as cuidava. Minha mãe não tinha homem, a única arma que ela usava era a palavra, era um poder de liderança muito grande porque ela não contava com religião. Eu tenho certeza que começa ali minha história e essa preocupação com as mulheres. Eu penso muito na recriação das ialodês ${ }^{18}$ que, na África, constituíam um poder. Eu acho que essas mulheres, essas Donas, essas Tias são um tipo de recriação das ialodês aqui no Brasil. Mais tarde, entro para o Ginásio e me lembro muito de uma aula de História dada por uma professora. Era o Colégio Paulo de Frontin e para ser admitida como aluna tínhamos que nos submeter a um concurso muito duro. Na escola inteira éramos duas ou três negras, percebíamos que não éramos bem-vindas naquele espaço. Era um colégio tradicional na Tijuca, só de moças de classe média, classe média alta. Nessa aula, a professora estava dando uma aula que falava sobre as origens da população brasileira. Ela dizia que os negros brasileiros descendiam de dois tipos básicos de negros: os bantos e os

18 A Ialodê era uma associação feminina cujo nome significa "senhora encarregada dos negócios públicos". Sua dirigente tivera lugar no conselho supremo dos chefes urbanos e era considerada uma alta funcionária do Estado, responsável pelas questões femininas. No candomblé ketu, costuma-se associar Oxum e Nanã como Ialodês. 
sudaneses. Segundo ela, os sudaneses eram uma maravilha, tinham ido para Bahia, para o Maranhão, eram adiantados, bonitos, altos etc. Os bantos, ao contrário, eram uns coitados, estúpidos, feios, era uma raça feia, boçal, baixa, atarracada, não servia par absolutamente nada. Ela dizia que para o Rio de Janeiro, Espírito Santo veio essa turba, ela chamava de turba! E explicava que era por isso que aqui só tinha negro ladrão, vagabundo etc. Nunca me esqueço dessa aula porque ela falava olhando o tempo inteiro para $\mathrm{mim}$ ! Eu me perguntava "O que eu tenho com isso? Eu não sou isso". Eu não me reconhecia naquela fala. Eu sentia que ela estava me atacando, mas com 11, 12 anos eu não entendia o porquê dela está me atacando. Eu ali já estava me sentindo negra e fora de alguns esquemas por ser negra. E dali começa algum tipo de consciência. Na verdade, foi essa professora que começa com isso. ${ }^{19}$

Elizabeth Calvet nasceu em 1960, no Rio de Janeiro, chamada pelas amigas e no movimento de Beth Calvet, faleceu em 10 de setembro de 2001, de causa desconhecida. Ativista lésbica e feminista, Beth fez ensino fundamental e médio nas escolas públicas do Rio de Janeiro e cursou dois períodos do curso de Odontologia, mas sempre teve desejo de intervir, de lutar, de mudar. Em 1994, Beth Calvet e sua companheira, Neusa das Dores, fundaram o Centro de Documentação Coisa de Mulher (Cedoicom) e, em 1996, organizaram o I Senale (Seminário Nacional de Lésbicas).

Eide Paiva, 51 anos, lésbica feminista, mora em Salvador. É professora da Universidade do Estado da Bahia, militante da liga brasileira de lésbicas e pesquisadora em gênero, raça e sexualidade.

Eu me casei, eu vim pra Bahia, cheguei na Bahia casada, acreditando no casamento, no amor romântico para sempre, queria ter filhos e fiz tudo isso. Meu casamento foi eterno enquanto durou, sete anos, até eu conhecer uma mulher, me apaixonar por uma mulher e perceber uma outra possibilidade de ser e viver. E foi nesse processo que eu conheci Jane Pantel ${ }^{20}$ do grupo GLB (Grupo Lésbico da Bahia). O grupo foi criado em 95.

Verônica Lourenço da Silva - no movimento é Verônica Lourenço -, paraibana, negra, feminista e livre, como ela gosta de se definir. Atuante no movimento de lésbicas, foi conselheira nacional de saúde pela liga brasileira de lésbicas. Nasceu em 1970, é candomblecista, Ialorixá e filha de Opará.

19 Entrevista dada para a sessão Mulheres Negras: do umbigo para o mundo, do site <www.mulheresnegras,org>. Acesso em: 25 ago. 2015, às $12 \mathrm{~h} 29$.

20 Jane Pantel, ativista lésbica, foi presidente do então Grupo Lésbico da Bahia, que foi fundado em 1995. Também integrou o grupo Palavra de Mulher e foi secretária-geral da ABGLT. Sua mãe, Jandira, que faleceu em 2011, foi protagonista de uma campanha publicitária para a II Parada Gay da Bahia, em 2003, na defesa da orientação sexual de Jane. 
A história de vida da Verônica é cercada pelos conflitos com o pai, com a violência sofrida pela mãe e, principalmente, pela religiosidade, herança de seu pai, que era de religião de matriz africana e filho de Ogun.

E aí a Mônica era minha melhor amiga, a gente ia pra escola juntas, se mexesse com Mônica mexia comigo e se mexesse comigo, mexia com ela também. Com três anos de idade, a gente começa no bairro e depois mais velha, com seis anos, sete, oito, eu não lembro bem a idade direito, enfim, foram os anos da escola, né? E depois a gente se perde, porque a família dela sai do bairro, se separa do pai, eles vão morar em outro bairro e ela vai morar com a mãe, tal. Mas aí, e assim, pra mim sempre foi muito natural eu sentir desejo por meninos e por meninas, mas especialmente pelas meninas [...] minha primeira descoberta, eu lembro que eu descobri masturbação jogando bola de gude, né? Porque quem já jogou bola de gude aqui sabe que a gente tem que fazer a roda no meio e aí tem as posições que você fica pra poder tacar na bola, qual era a posição que eu geralmente ficava? Essa aqui, sentada em cima do meu pé, do meu calcanhar e jogava e aí o peso e uma posição que era muito bacana e eu comecei a dizer oi? [...] Mas aí tudo proibido, eu não podia nem falar, como eu falei, bem lá na frente, de falar pra minha mãe que eu não ia poder fazer educação física porque eu estava de boi, ou menstruada e ela: "Meu Deus, minha filha é uma perdida, como é que você vai para a escola?", Porque lá em casa, na nossa geração, a menina tinha que lavar a calcinha e botar pra secar muito escondido, seu paninhos, porque não era absorvente, eram paninhos de boi, que a gente tinha que lavar e deixar bem alvinho e pôr pra secar bem escondido, ninguém poderia saber do nosso ciclo, no máximo você podia dizer a sua mãe e olhe lá... então eu era uma perdida, e eu dizia: "Mas mãe, toda menina da minha idade menstrua, o professor disse que se eu faltasse ele me botava falta, então eu disse que estava menstruada e eu não queria fazer, então ele me deixou quieta e ainda me botou presença e só fazer um trabalho", e era tão legal dizer a verdade, então começa aí e depois começa a outra coisa, começa a namorar escondido porque só poderia namorar depois dos 14 anos, aliás, depois dos 18 anos e namorar pra casar. Um dia levei o primeiro namorado: "Boa noite", "Boa noite", "Mãe, esse é Ednaldo!" o primeiro que apresentei a ela, com 18 anos, e ela: "Laura Mendonça, vocês vão casar quando?". Eu já tinha namorado horrores antes disso e depois disso, lá pelos 18, 19 anos [...] Aquela história que você olhava e se testava, eu queria ficar com aquele menino e ficava, depois eu falava: "ah, gente, que chato! Que quero ficar é com meninas...”. E aí comecei, cheguei pra minha mãe, que embora não podia namorar, se namorar ela me dava uma surra, imagina ser sapatão. E quando eu cheguei pra ela e disse: "Mãe, oh, a partir de hoje eu vou começar a namorar com meninas", ela riu da minha cara e disse que as mulheres da nossa família eram muito fogosas para serem sapatão, porque ela sabia! "Você pensa que eu sou besta? Que eu não sabia? Quando você vem com o caju, eu já vou com as castanhas, minha castanha já estava assada". Foi assim que ela disse. "Você tá dizendo isso é pra quando os caras chegarem aí na porta eu achar que é tudo viado". E eu: "Tá bom mãe, mas eu te disse." Aí eu comecei a namorar e namorava na porta. Mas pra mim foi nessa naturalidade.

Ao escrever a histórias destas mulheres, me recordo que muitas de suas dores e 
vivências são também sentidas em mim, como passagens em minha vida. Ao me desafiar escrever minha história para integrar este trabalho, finalizo esta seção descrevendo trechos de minha vida cujo objetivo é dialogar com as entrevistas em suas histórias e lutas.

Nascida em São Paulo em 1971, filha de descendentes italianos, de classe média baixa, vivi minha infância durante o regime militar que impunha para a minha família um silêncio sobre assuntos relacionados a política e sobre a situação do país. Como a maioria das famílias italianas, a minha não fugia a regra e se reunia com frequência em almoços de domingo e jogos de baralho durante as noites o que desenvolvia em todos nós, filhos/as e netos/as o desejo pelos jogos e em uma das ocasiões que pequena jogava com minhas amigas de infância na frente da calçada do prédio tive o primeiro contato com a ditadura, neste dia, mesmo sem ainda entender, a censura e o medo da ditadura civil-militar fez minha mãe cercear minha brincadeira de infância com medo de que os militares entendessem aquela brincadeira como atividade de subversão entre duas crianças.

Anos depois, com 13 anos na campanha pelas Diretas Já, vivencio a minha primeira experiência de ativismo. Sabendo da reprovação de meus pais, disse que sairia mais tarde do ensaio da banda marcial que participava no colégio e me dirige a Praça da Sé para me juntar a milhares de pessoas sem saber ao certo o que eu queria, ou o que significava o movimento pelas Diretas Já, mas senti naquele momento uma imensa emoção que definitivamente brotou em mim, o desejo de ser ativista. Ao retornar para casa, não hesitei em contar a minha mãe onde estava, levei umas broncas, umas palmadas, mas fiquei com a emoção primeira de que havia algo que em minha casa não se falava que dizia respeito a todos nós e pela primeira vez ouvi do meu pai que eu tinha que ter cuidado com aquelas pessoas, pois eles eram comunistas., se eram ou não naquela época eu não sabia, mas hoje sei que desde então estive do lado que acredito.

\subsection{Lesbianidades, Feminismo e Ativismo}

Segundo Lardinois (1995), encontram-se registros do uso da palavra "lesbianismo" desde 1870, ainda que tenhamos conhecimento de que relações afetivo-sexuais entre mulheres existam desde a Antiguidade. Essa identidade que hoje nomeamos de lésbica nem sempre assim foi chamada, e a história já a ordenou de sáficas, lesbianas, entendidas, fanchas, butchs, femmes, entre outras. 
Historicamente, as práticas homoeróticas femininas foram marcadas pela heteronormatividade. A reprodução dos padrões de gênero aceitos pela sociedade impunha aos casais de mulheres homoeróticas a identificação de uma como masculina e a outra feminina. Esses sinais, por muito tempo, e ainda nos dias de hoje, principalmente em regiões mais distantes dos grandes centros, marcam os corpos lésbicos nas construções de suas expressões binárias (NOGUEIRA, 2005).

Navarro (2004) diz que as diferenças não existem dessa forma por si só, elas são monumentos sociais arquitetados em uma ampla disposição de poderes, cuja estrutura em rede garante sua solidez. A heterossexualidade, conforme nos apresenta Adrienne Rich (1980), foi institucionalizada como compulsória, conduzindo o processo de subjetivação feminina. Estabelece o lugar da fala e da atuação, delimitando funções e induzindo comportamentos.

Esse demarcado corpo lésbico, nestes termos, torna-se na constituição de um corpo político que parece encontrar limitações ao se expressar, mas a expressão desse corpo é signo da visibilidade e da resistência lésbica.

Assim, o corpo político das lésbicas é controverso, pois se torna político quando resiste à norma e à heterossexualidade compulsória, mas, ao mesmo tempo, é um corpo abjeto, e invisibilizado na sua condição.

Esse senso comum que universaliza a definição homossexual como desviante, ou seja, o gay é afeminado e a lésbica masculinizada, e a reprodução heterossexista na relação de pessoas homossexuais e desejos pelo mesmo sexo colado ao gênero. De um lado, ainda persiste o entendimento folclórico, mas muitas vezes reproduzidos pela cultura gay e lésbica, os meninos mulherzinhas e as meninas masculinizadas, ou ainda a alma de mulher aprisionada num corpo de homem ou do homem preso no corpo feminino (SEDGWICK, 2007).

Nesse sentido, muitas buscavam se compreender e descobrir aquele sentimento marcado pelo silêncio e pela necessidade de ter e conhecer iguais. Foi em busca de saber quem era que Carmem fala da literatura de Cassandra e dos estereótipos.

Eu tava me lembrando da minha adolescência, né, quando eu comecei a sentir algum desejo por mulher e não sabia reconhecer isso, não sabia que lugar colocar, né? O que a gente faz? Eu sou uma pessoa que adoro ler, a minha vida inteira, a minha mãe, eu tinha 8 anos, ela entrava duas horas da madrugada no meu quarto e fechava a luz por que eu tava lendo ainda e tinha que ir para o colégio no outro dia cedo, né? E o que caiu nas minhas mãos? Literatura lésbica na época era Cassandra Rios. Cassandra Rios é desgraça da primeira página à última. E aquelas histórias, eu pensava, eu não quero pra mim, isso é sofrimento atroz. As mulheres tinham que se fantasiar de 
homens para poder ficar com mulher, não que elas quisessem se travestir, mas para estar com uma mulher em uma boate, uma tinha que ir vestida de homem e a outra de mulher. Se não, você não era aceita, você não conseguia entrar no lugar. As heroínas todas se matavam ao final da história e eu ficava pensando: Eu quero isso pra mim? Eu não quero essa vida pra mim! Isso é só tristeza, isso é só desgraça, não vou ficar cultivando desgraça.

Esse processo de reconhecimento corporal caminha paralelamente com o processo de saída do armário, pois nossos corpos nos tiram do armário antes mesmo de nos percebemos lésbicas, como reforça Carmen em seu relato.

Depois adulta, um dia Maria Angélica Lemos ${ }^{21}$ estava fazendo um livro sobre histórias de mulheres lésbicas e me perguntou: “- Carmen, quando é que você se deu conta que você era uma mulher lésbica?" Eu disse: "Demorei tanto. Todo mundo sabia, menos eu!" (risos). Né, porque realmente já tinha uma aparência, já tinha as formas de brincar que não eram próprias de meninas, então é bem possível que as pessoas descobriram que eu era lésbica, eu acho antes de mim, antes de eu mesma saber, né?

Sobre sair do armário, os relatos foram bastante diversos para algumas, como a Carmen, cujo corpo a denunciou e o externo lhe contou quem ela era. Para Heliana foi paradoxal com o sofrimento na perda de sua filha, a descoberta de um novo amor feminino e a construção da negritude como identidade.

Foi um processo tranquilo. Eu sempre percebi que mulheres me seduziam desde muito jovem. Fui apaixonada por várias artistas de cinema, professoras, colegas de escola. Mas meu interesse pelos homens também era muito grande. Aos 22 anos fui viver com um homem 13 anos mais velho, médico, desquitado. Tivemos uma filha que, infelizmente, morreu em virtude de meningite. Após esse acontecimento, meu casamento acabou. Devido à depressão, busquei na religião alguma forma de consolo e, assim, cheguei ao candomblé, tornando-me ekedy. Nesse percurso, conheci um amigo, Francisco José, ele era gay, trabalhava na Fundação Getulio Vargas. Através dele fui apresentada à minha primeira namorada. Começamos a sair para conversar, ir ao cinema, até ficarmos inseparáveis. Na época eu vivia uma relação hétero, e só me dei conta dessa paixão quando meu interesse sexual surgiu e eu comecei então a me relacionar com ela. No princípio, depois de assumir esse romance com ela, foi difícil, pois eu mantinha o outro relacionamento e precisava arrumar desculpas para chegar tarde. Sorte que naquele tempo não havia celulares (risos). Depois de quase um ano, rompi o meu outro relacionamento e fomos morar juntas até o seu falecimento. Digo que me sentir lésbica não foi difícil, pois o processo de sentir-me negra e ocupar um lugar na sociedade a partir disso foi muito mais doloroso. Esse assumir negra foi um caminho longo, com altos e baixos.

21 Maria Angélica Lemos, ativista lésbica, conhecida pelas filmagens e vídeos realizados em encontros. Maria Angélica é fundadora da Comulher, em 1984, quando ainda existiam poucas organizações e, na época, ela e as demais fundadoras trabalharam com então feminista e deputada pelo estado de São Paulo Ruth Escobar. 
Esse processo de descoberta, saída do armário, violento e proibido, foi expressado fortemente pela ativista Marisa:

Este foi o processo de não descoberta da minha sexualidade tanto hétero quanto homo, apenas a proibição e a repressão ao desejo sexual. Eu chorava sozinha no meu quarto, sentada ao chão e debruçada sobre minha caminha de solteira, eu cobrava de Deus, por que eu? Por que Deus permitia que eu fosse por um caminho que não podia? Por que Deus não tirava de dentro de mim aquele amor? Que nome tinha o que eu era? Devido à fortíssima repressão que eu enfrentei dentro da minha família, eu experimentava pela primeira vez na vida um forte sentimento de injustiça e desejei ardentemente dar fim a minha vida e tentei, mas não obtive êxito, creio que uma forte vontade interior de conseguir vencer, o que eu nem podia naquele momento chamar de preconceito me fez tomar bem menos comprimidos do que os necessários para morrer. Violência doméstica é violência, mas as iniciais eram impedir de nos ver, de falar ao telefone, prisão domiciliar, quando meus pais saíam de casa, passaram então para os tapas no rosto, enforcamentos, até uma faca uma tarde apareceu, ameaças de internação em colégio interno de freiras e sempre, sempre, sempre a ordem: "quer ser o que você é? então é desta porta para fora". Eu era uma menor de idade e perdia naquele momento todo amor, carinho, proteção e afeto da minha família, estava sozinha, nunca tinha trabalhado ainda e me sentia muito vulnerável para sair de casa, sentia um imenso medo, pois também a polícia, dentro do contexto ditatorial, era uma ameaça e não uma proteção para ninguém, para onde ir? A quem pedir ajuda? Minha sociabilidade era apenas com a família e minha namoradinha, não conhecia ninguém que seguraria a barra de me aceitar em casa. Não existia nada além da repressão a tudo, a todas as formas de associação, a todas e todos então ex-cidadãos brasileiros. Eu queria ler sobre o assunto, mas como, se a censura não permitia que nada que não tratasse apenas da manutenção da moral e os bons costumes fosse publicado no Brasil? $\mathrm{O}$ que aos poucos fui tomando ciência é de que a homossexualidade era pecado e doença. O único acesso possível era o dicionário, ajudou. Eu olhava a Maria Bethânia, a Gal Costa e entendia magicamente que elas só podiam ser lésbicas. Eu olhava o Caetano Veloso e o Gilberto Gil e achava que eles eram gays. Eu só tinha uma determinação para romper com o ciclo da violência, quando eu fizesse 18 anos, em 1971, eu ia fugir de casa. E foi o que eu fiz. Eu voltei a estudar, fui fazer inglês. A minha amada fazia a mesma escola de inglês, só que em horário diferente, como a família dela foi mais light, deixou a solução do "problema" sobre as costas dos meus pais, nós nos encontrávamos antes de eu entrar na aula e íamos para o banheiro, coitadas das demais alunas que quiseram usar o banheiro enquanto estávamos lá, não sei como se viravam. Após os 18 anos, quando fui embora de casa, quando minha família, sobretudo os meus pais perceberam que haviam me perdido, caíram em desespero e fizeram um imenso arranjo para que eu retornasse, com a promessa de que jamais interfeririam na minha vida, em especial na minha sexualidade. Caramba! Foi verdade mesmo. Eles jamais falaram alguma coisa contra ou me atacaram moral ou fisicamente. Com os anos, minha mãe se tornou, sem a menor sombra de dúvidas, a minha melhor e maior amiga, confidente, me defendia contra os preconceitos daquelas pessoas que achavam que iam me ofender me chamando de lésbica, ela não aceitava e prontamente se erguia contra. Ela me consolava e amparava quando das minhas separações 
amorosas. Há muitos anos, minha família em geral é unânime em afirmar que sentem orgulho de mim.

Eide descreve seu processo de saída do armário com a descoberta de amores por mulheres, pela militância lésbica na Bahia e as marcas da lesbofobia vivida.

Eu conheci Jane Pantel mais ou menos nessa época que frequentava e namorava com uma menina que era bibliotecária. Então, descobri um grupo chamado do GLB, eram reuniões para formação do grupo e nós fomos, participamos daquilo ali tudo e tudo muito encantador, tudo muito novo. Mas, eu não pertencia àquele contexto porque era um contexto de uma lesbianidade periférica e negra. Eu era a única branca, classe média, já tava na universidade, já tava num outro contexto. E não tinha dimensão daquelas coisas, então tudo foi assim muito, mais muito novo e sedutor demais. E a minha saída do armário pública foi muito em função do GLB, porque foi, eu era estudante de Biblioteconomia e acreditava naquilo tudo, eu não podia não expressar aquilo, as minhas amigas que não eram daquele universo precisavam conhecer também, saber que aquilo era possível, que aquelas experiências eram possíveis. Aí levei Jane Pantel pra minha faculdade, eu era aluna, fazia um seminário, ela foi falar daquilo daquele lesbianismo que eu não sabia nem o que era, embora eu já fosse lésbica, não tinha vivência de organização. Então naquele dia ali na faculdade, eu me apresentei, me anunciei lésbica, e foi um grande choque, porque "como assim? Não tem cara de sapatão". É mãe, ainda tinha marido, enfim. Essas coisas todas, mas a Jane Pantel e o GLB teve um papel fundamental por que me mostrou a organização política e fiquei naquela vivência até conhecer a Amélia e ver outras histórias, e fui viver outras histórias, por que o movimento já não era, como eu disse, eu não pertencia porque era um movimento de periferia e eu sempre era outra, aquela estranha, eu era uma estranha no grupo por várias questões, questão de classe e questão racial. Mas a lesbianidade, ela eu percebi que podia e que eu podia viver as minhas histórias de uma outra forma e fui caminhar, entrei para a universidade, fui ser professora, viver um monte de coisa. Até conhecer a cara da lesbofobia, que eu também não conhecia, que foi no exercício docente, foi trabalhando a questão da violência contra as mulheres com o Movimento Feminista, e aí quando eu sofri a violência, a lesbofobia. Eu recebi uma carta anônima com ameaça de morte, uma coisa que me abalou profundamente. Aí eu procurei, lembrei de Jane Pantel, lembrei dessa força política que é a organização de lésbicas e busquei, mas não encontrei na Bahia, por que já estava em um momento de fragilidade do movimento local, aí foi que eu entrei na LBL.

Entendo, assim, que nosso ativismo é feito também pela resistência e persistência na visibilidade de um corpo feminino que se expressa masculino, e masculino que se expressa feminino.

A participação das lésbicas no movimento LGBT iniciou-se em 1979, com a adesão ao Grupo Somos, como explorada anteriormente, mas foi a partir de 1980, quando ocorreu a primeira ruptura do movimento, que as lésbicas se organizaram enquanto grupo. 
Participei e presenciei alguns "rachas". Em maio de 1980, as lésbicas deixaram o Grupo Somos, e nos organizamos como um grupo autônomo, o LF, Grupo Lésbico Feminista (Marisa Fernandes).

A organização das lésbicas, enquanto movimento, foi chamada pelos gays na época de divisionista, com a saída delas do grupo e a posterior constituição do LF (Lésbicas Feministas). A ativista lésbica feminista Marisa Fernandes $(2004)^{22}$ descreve a saída como uma resposta ao machismo e ao patriarcado presentes no movimento denominado homossexual brasileiro.

Dialogando com esse contexto, o início da organização não só determina os rumos do movimento até os dias de hoje, mas também desmascara como o corpo feminino é abjeto ao movimento, e por isso, subcategórico nas instâncias e disputa de poder dentro do movimento (KIRCHNER, 2014).

A necessidade de se autoafirmar feministas em contraponto à agenda majoritariamente gay dentro do movimento LGBT é marcada desde a fundação do movimento de lésbicas, quando do rompimento no grupo Somos, e permanece até os dias atuais. Essas idas e vindas, ao contrário das minhas expectativas quando antes das entrevistas, não necessariamente tiveram relação com a agenda gay, mas sim com a necessidade de se autoafirmar muito mais quanto mulheres, lésbicas e feministas. Carmem Luiz, que na sua adolescência buscava encontrar referências para fugir dos estereótipos, reflete isso em sua fala.

Então, buscava fugir disso o tempo todo, e uma pessoa que eu tenho como referência, que inclusive não foi citada aqui durante a história, mas eu acho que é uma história da maior importância, foi Rosely Roth. Rosely, que era uma menina rica, branca e judia se assumiu e lutou pelo nosso direito de ser lésbica. Criou um grupo de mulheres lésbicas que acharam, que chamavam LF e depois virou Ação Lésbica Feminista.

É certo que a maioria de nossas vidas e histórias foi construída de forma diversa das dos homens, para feministas, o privado tem sido geralmente identificado ao doméstico, à família patriarcal, que determina o lugar das mulheres.

22 Movimento de Mulheres Lésbicas no Brasil: sinalizando algumas conquistas e desafios para o século XXI.

Revista GALF - Grupo de Activistas Lesbianas Feministas. Tercera Época, Lima, n. 18, dic. 2004.

Disponível em: 〈www.galf.org>. 
Esse lugar que nos silencia e normatiza a nossa sexualidade é simbolicamente rompido quando da saída do armário, pois nossa sexualidade se torna pública e nossa vagina, nossa bandeira. Saímos, então, do espaço doméstico e privado para a esfera pública, onde é preciso fazer política, falar e se organizar.

Desde então, dentro do movimento LGBT, lésbicas sempre carregam estereótipos como "machona", "racha", "feiosa", "mal-amada" e, portanto, não dignas de ocupar o lugar dos homens e também não são representantes aptas do feminino. A conotação pejorativa atribuída à lesbianidade tem sido feita como forma de desqualificação das ativistas que, ao longo de todos esses anos, ocuparam espaços para além do movimento LGBT, especialmente no movimento feminista. Essa aproximação com a agenda feminista sempre foi também outro motivo para ocupar um status diferenciado e inferiorizado na agenda LGBT.

Nesse sentido, essa relação entre privado e público implica não apenas a determinação do gênero a eles atribuídos, mas também a sugestão de que, quando esse espaço doméstico é ultrapassado em direção à esfera pública, essa passagem não se faz acompanhar por formas de identidades distintas daquelas próprias às esferas privadas. Com isso, carrega-se nela todos os estigmas aos marcadores de gênero no corpo marcado (BOTELHO, 2012).

A vivência da lesbianidade é a afirmação da identidade lésbica que, historicamente, nem sempre teve o mesmo significado do que conhecemos hoje. A vivência lésbica faz com que mulheres que se relacionam com outras mulheres rompam a lógica essencialista e heterossexista e tornam visíveis aquilo que foi ocultado, conforme nos relata Louro (1997). Ela continua nos dizendo que lesbianidade pode se constituir em uma forma mais invisível, pois abraços, beijos, mãos dadas, a atitude de "abrir o coração" para a amiga/parceira são práticas comuns do gênero feminino em nossa cultura.

Esse contínuo cultural que invisibiliza as mulheres na sociedade, seja ela lésbica ou não, faz com que as lésbicas, na tentativa de afirmarem sua identidade, muitas vezes reforcem visões estereotipadas da sociedade que as colocam em situação de exclusão social, colocandoas em situações de vulnerabilidades que potencializam os mais diversos sofrimentos físicos e psíquicos e, com isso, a autonegação de seus direitos e do sentimento de pertencimento enquanto cidadã.

Essa invisibilidade inclusive se dá na história dos grupos e das ativistas lésbicas que, muitas vezes, tendo suas histórias contadas por outras vozes, são fragmentadas em lapsos temporais. E foi dessa forma que tomei conhecimento do Grupo Libertário Homossexual 
(GLH), um grupo de lésbicas na Bahia. No livro Lesbianismo no Brasil, Mott (1987), ao retratar a valorização das guerreiras amazonas no movimento de lésbicas, cita: "as guerreiras têm servido de inspiração para inúmeras obras literárias e artísticas defensoras dos direitos do safismo, chamando-se Amazonas a primeira e única revista editada pelo Grupo Libertário Homossexual, a única associação de lésbicas fundada na Bahia em 1982.”

Eide Paiva, no entanto, durante o III Seminário de Memórias e Visibilidades de Lésbicas e Mulheres Bissexuais, ao contar sua história e debater a história do movimento com a ativista Yone Lindgren, ${ }^{23}$ ressalta a fundação do GLH, também em 1979, mesmo ano em que foi fundado o LF, que depois se tornou GALF.

Mas o que eu queria ressaltar, Yone, é que o GLB não foi o primeiro grupo de lésbicas da Bahia, o primeiro grupo de lésbicas da Bahia foi GLH, Grupo, Grupo Libertário Homossexual, que foi criado exatamente em 79. Então, o GALF não foi o primeiro grupo e o único grupo a ser criado. O GLH surgiu no embalo do Movimento Estudantil, do Movimento de Esquerda né? No embalo mesmo dos tempos da ditadura. [...] Eu tive a oportunidade de encontrar a fundadora desse grupo e de entrevistá-la, a Lurdinha. Então ela fala exatamente isso, ela é branca, também de classe média, estudante que sai do interior da Bahia e vai pra capital pra estudar e entra no Movimento, fez parte da Libelu. ${ }^{24}$ Então, toda aquela vivência de combate ao regime e aí é quando tem o Congresso da UNE, acho que é o $31^{a}$ Congresso da UNE, o conhecido congresso da reconstrução, e ela estava ali, ela estava naquele movimento, ela foi uma das protagonistas. E aquele programa e aquele Congresso elegeu Rui Cesar, um estudante de 22 anos do Curso de Comunicação, gay. E quando ele se assumiu, vazou, né, essa coisa, não sei se vazou, ou ele era assumido, pois todo mundo sabia, mas aquela coisa de não ser falada, por que a homossexualidade era associada à subversão. Então quando se descobriu a homossexualidade de Rui, a esquerda, como a Lurdinha fala: "os esquerdistas" da Libelu e dos partidos começaram a criticar e foi aí que ela, eu acho que ela tomou consciência de que tinha alguma coisa errada e que podia fazer um outro movimento, e daí surge o GLH. Mas não surgiu só do desejo de Lurdinha, tinha uma professora lésbica, branca também, a professora Margot Piva, recém-chegada do exílio, uma das fundadoras do Brasil Mulher, então tinha um contexto feminista, um incentivo feminista pra se criar o GLH. [...] quando Lurdinha termina a faculdade e tem que ir para o mercado de trabalho, e aí já não tinha o tempo necessário pra continuação do grupo, ele se ele acaba. E aí na Bahia tem esse silêncio, esse esvaziamento a partir de 1987.

23 Yone é ativista lésbica. Iniciou seu ativismo com a fundação do Somos Rio de Janeiro e escreveu esporadicamente ao Jornal Lampião. Fundou o Grupo D'Ellas, ABGLT, LBL e ABL.

24 Liberdade e Luta: Libelu. A corrente de inspiração trotskista que seduziu centenas de jovens em meados da década de 1970, quando o movimento estudantil começava a renascer no Brasil, ainda durante a ditadura militar, ao qual Paulo Leminski dedicou um poema: "Me enterrem com os trotskistas, na cova comum dos idealistas, onde jazem aqueles que o poder não corrompeu, me enterrem com meu coração na beira do rio, onde o joelho ferido, tocou a pedra da paixão. (Paulo Leminski. Para a liberdade e luta). 
As lésbicas, ao organizarem-se independentemente dos gays (de 1979 a meados de 1981) com o nome de Grupo Lésbico Feminista (LF), afirmam a necessidade de dar voz às suas especificidades e tornam o LF, segundo a ativista Miriam Martinho ${ }^{25}$ :

O pioneiro no tratamento da questão homossexual, dentro do Movimento Feminista, e da questão da mulher, dentro do Movimento Homossexual, bem como na elaboração da primeira publicação lésbica do país, intitulada ChanacomChana, datada de janeiro de 1981.

Em outubro de 1981, lésbicas que optaram por consolidar a militância especificamente lésbica e feminista fundam o Grupo Ação Lésbica Feminista (GALF), que permaneceu atuante durante praticamente toda a década de 1980, mas que transitou entre a agenda feminista e a agenda do movimento LGBT. É nesta época que ocorre a primeira ruptura do movimento de lésbicas, conforme relata a ativista Miriam Martinho:

Nos últimos meses de 1980, o Grupo Lésbico Feminista, a partir de uma série de conflitos internos, sofre um racha, com a maior parte de suas integrantes deixando a militância, algumas outras formando um outro grupo lésbico (Terra Maria), ou indo atuar em organizações feministas (SOS Mulher), e outras ainda decidindo dar continuidade ao grupo lésbicofeminista com outra perspectiva. (Revista Um Outro Olhar, 21/08/2012).

Para a ativista Marisa Fernandes, que vivenciou esse mesmo momento, o relato sobre esse primeiro racha precedeu de uma reflexão sobre o movimento, seus rompimentos e subdivisões que, segundo ela, ocorreram e ainda ocorrem devido à falta de compreensão e respeito pela trajetória das ativistas e suas histórias. Ela, que faz um paralelo na história com o momento atual do movimento, considera que o excesso de protagonismo reflete uma miopia política que tem destruído todas as tentativas de unidade, ainda que se respeitando as diferenças, os consensos.

Inicialmente de sonhadoras e sem referências, sem ancestralidade em nosso movimento de lésbicas feministas, passamos para um estágio de que as referências são os movimentos heterofeministas, o movimento gay, os partidos políticos de onde muitas e tantas outras são provenientes, a formação político-partidária que obtiveram. Os modelos de Conferências, todos esses modelos são reproduções óbvias de práticas de poder masculino, de modelos patriarcais imperantes, do reforço das normas e práticas justificadas por serem historicamente construídas. Se tudo isso não levar ao questionamento, às rupturas, às separações, aos desligamentos, então

25 Depoimentos da ativista (este e o próximo) foram extraídos do site <http://www.umoutroolhar.com.br/2012/08/agosto-com-orgulho-os-primordios-da.html>. Acesso em: 16 jan. 2016. 
significaria que o movimento deixou de ser movimento para ser fixo. Os "rachas", as rupturas seriam saudáveis, são saudáveis porque pressupõem a construção de modelos e práticas diferentes, no entanto o que se observa é que não ocorre dessa forma, tudo se reduz na busca pela conquista de espaço de poder, de afirmar vaidades pessoais, empoderamento individual, o que leva à desqualificação das outras, das divergentes, das "históricas".

Ainda, continuando em sua reflexão sobre as rupturas, Marisa Fernandes nos conta que vivenciou esse primeiro racha no movimento de lésbicas, assim como Miriam Martinho.

No final do ano de 1980 acontece um "racha", um esvaziamento do GALF. Uma parte do grupo foi o recém-formado SOS Mulher (grupo feminista), que atendia mulheres vítimas de violência doméstica, basicamente. Outra parte fundou um outro grupo de lésbicas chamado Terra Maria Opção Lésbica. Na organização das caminhadas lésbicas também houve um racha, primeiramente organizado pelo grupo Umas \& Outras com o MO.Le.Ca (Movimento Lésbico de Campinas) e, posteriormente a organização é tomada pela LBL-SP.

Com o rompimento e o esvaziamento do GALF (1981-1989), a organização passa a ser dirigida pelas militantes Miriam Martinho e Rosely Roth. Nessa reorganização, o GALF volta a produzir a publicação ChanacomChana como boletim, e constrói a primeira biblioteca sobre a temática lésbica no Brasil.

Fizemos as primeiras reivindicações junto a políticos pelo combate contra a discriminação, as primeiras articulações entre ativistas lésbicas em nível internacional (em particular da América Latina), as primeiras aparições públicas nos meios de comunicação nacionais (mídia impressa e televisiva) e permaneceu atuante durante praticamente toda a década de oitenta (19811989), ao contrário das outras poucas organizações lésbicas da época que tiveram vida efêmera.

As aproximações com o movimento feminista e negro são relatadas por várias ativistas ao longo de suas falas, às vezes como fato de importante intersecção dessas ativistas que não entendiam ou entendem a luta em separado do enfrentamento ao patriarcado, machismo e racismo e, por vezes, para descrever as dificuldades em serem aceitas ou ainda terem espaço para pautarem suas demandas e a lesbianidade.

Marisa Fernandes (2014) sobre a relação do movimento feminista com as lésbicas e pauta na época chamada de minorias, relata que após a organização das lésbicas no LF como subgrupo dentro do Somos, em outubro de 1979, começam a participar, em dezembro, das 
reuniões de Coordenação para o II Congresso da Mulher Paulista, que ocorreria em 8 de março de 1980, na PUC, em São Paulo.

Nossa participação na Coordenação do II Encontro da Mulher Paulista não foi bem aceita, já que pela primeira vez se colocava a questão da sexualidade da mulher e do seu prazer sexual como uma possibilidade e um direito. Como a nossa presença criou uma situação incômoda, várias formas de preconceitos foram sentidas e, para contornar e causar menos controvérsias, usamos mais o nome do Grupo Somos do que o Lésbico Feminista.

Nessa primeira parte do relato é perceptível a solidariedade feminista das lésbicas do LF, que preferiram minimizar o incômodo ao movimento de mulheres se expressando como grupo homossexual ao marcar suas presenças como mulheres lésbicas feministas e organizadas.

$\mathrm{Na}$ abertura do Congresso, com a intenção de dar visibilidade à existência lésbica, colocamos no saguão da PUC um painel, "Amor Entre Mulheres", com algumas fotos. O painel não resistiu e pouco tempo depois o encontramos destruído, as fotos rasgadas e jogadas ao chão. No primeiro dia ficamos todas juntas, em um único grupo, e nele éramos maioria, mas havia oitenta outros grupos acontecendo ao mesmo tempo, assim nosso efeito foi limitado. No segundo dia nossa tática foi se espalhar por outros grupos buscando assim dar maior alcance as nossas ideias. Mas foi tudo em vão, o clima geral do Congresso estava muito difícil, assim sendo, nossas reivindicações não causavam o impacto que desejávamos, a não ser animosidade. Nossa primeira inserção no movimento feminista, por meio deste II Encontro, de fato foi mesmo muito traumatizante. Apesar de estarmos em treze participantes, éramos bastante inexperientes. As mulheres ligadas a organizações políticas de uma esquerda autoritária, centralizadora, patriarcal e reacionária, pregavam não existir violência contra a mulher, mas sim a violência ditatorial contra homens e mulheres da classe operária e que propostas de se refletir sobre as especificidades das mulheres eram pequenoburguesas e elitistas e que pouco interessavam ao povo e à revolução. Chegaram a repudiar o Congresso, acusando-o de ser divisionista da luta de classes (a luta maior) e contrário à luta contra a ditadura. Essas mulheres viram, no II Congresso, a oportunidade para divulgar suas posições, não respeitavam as decisões da maioria, querendo impor propostas, causando tumultos e dividindo o movimento de mulheres. Agiam intencional e premeditadamente, foram ao II Congresso levando megafones, dispostas a substituir a mesa democraticamente escolhida para dirigir os trabalhos. Não conseguindo, chegaram até a agressão física e invadiram o palco, assustando o plenário e impedindo o encerramento do Congresso, o que só foi feito dias mais tarde, apenas com a participação da Comissão Organizadora. As feministas redigiram um Manifesto em apoio às prostitutas, para ser lido durante o Congresso. O manifesto apontava a preocupação com as contínuas agressões físicas e extorsões a que estão submetidas as prostitutas de São Paulo, por parte da polícia, e, cientes de que a situação era muito grave, apresentava uma série de argumentos que envolvem as mulheres na prostituição, entre outras: “- por que a prostituição é fruto da repressão sexual e dupla moral sexual, que nos divide em "Santas" - mães, esposas e donas de casa, sem direito à sexualidade - e "Putas" - que satisfazem os 
desejos sexuais masculinos?; - Por que a prostituição é fonte de enormes lucros para a própria polícia, que cobra 'taxa de proteção' dos exploradores do lenocínio, tornando-se a maior e impune exploradora da prostituição" [...]. O Manifesto não foi lido durante o Congresso, impedido pelas mesmas mulheres representantes de grupos políticos que consideravam a questão das minorias e as especificidades das mulheres coisa secundária, uma luta menor. O LF teve mais êxito, pois levou um documento por nós elaborado e impresso, de forma que foi possível distribuir entre todas as participantes durante o Congresso. O documento (Anexo 1) foi o primeiro a tratar a questão da violência doméstica e sexual que circulou no Movimento Feminista.

Não diferente, Heliana e Neusa das Dores também têm sua militância interseccionada com o movimento de mulheres e o movimento negro. Heliana, que tinha as questões raciais e de classe em conflito devido à sua história familiar e entrada no movimento, dá voz a este fato.

Iniciei minha militância em 1978 no IPCN (Instituto de Pesquisas de Cultura
Negra) quando me interessei pelas pautas do Movimento Negro. Por ter
nascido em uma família de classe média, minha mãe era professora e meu
pai estatístico, sempre vivi com conhecimento sobre as questões raciais, mas
o preconceito de classe permeava toda minha formação. Por exemplo, nós
(minha família) éramos negros, porém a população negra de comunidade e
da favela eram os neguinhos do morro. Essa dicotomia de identidade racial
versus classe era fortalecida pela família paterna, que era descendente do
prof. Hemeterio dos Santos, o primeiro professor negro a dar aula no
Colégio Militar e Instituto de Educação. Ele deu seu nome a uma sala no
Colégio Militar, assim como é homenageado tendo seu nome em uma escola
pública no bairro de Jacarepaguá no RJ.

Nesse relato, Heliana nos conta sobre a dicotomia classe e raça que incidiu sobre sua formação política no movimento e na busca pelo seu lugar, e segue nos contando:

Após ficar no IPCN, algumas mulheres negras fundaram o Fórum de Mulheres Negras RJ e eu começo a participar dessas discussões de gênero e raça. Participo dos I e II Encontro Estadual de Mulheres Negras, e dos I e II Encontro Nacional de Mulheres Negras, ao mesmo tempo em que começo a participar das discussões feministas. Tanto num espaço como noutro, começo a conviver com lésbicas. Algumas assumidas, outras não. Nesse momento eu vivia minha primeira relação lésbica, como já contei, e é quando minha companheira morre que participo ainda mais desses eventos e, socialmente, posso dizer que aproveitei para vivenciar esses sentimentos.

Na mesma trilha de intersecções, Neusa também inicia sua militância antes de se aventurar no movimento de lésbicas, inicia ainda no movimento estudantil, passa pelo 
movimento sindical, pelo movimento negro, até que âncora sua negritude guerreira no movimento de lésbicas.

Primeiro participo do movimento estudantil. Mais tarde, eu vou para o movimento sindical e bem mais tarde para o Sepe (Sindicato Estadual de Profissionais de Ensino). Antes disso, tentei o Movimento Negro, mas ele não me agradou, achei que era uma coisa muito elitizada, não era o que estava buscando na época. Me encontro melhor em 1979, no movimento sindical. Como professora, as coisas aí começam a se misturar. Vêm as questões de mulher, de negra, de professora, de trabalhadora. Montamos alguns grupos de trabalho. Coincide também com um projeto que a Prefeitura lança, chamado Zumbi, que colocava uma série de discussões de negritude para dentro das escolas. Junto com isso, criamos um grupo de reflexão constituído por mulheres. Há a necessidade de que as professoras entendam a questão de gênero. O machismo da escola é terrível, porque as professoras são muito machistas. São também racistas, mesmo que sejam negras. Fundamos em Jacarepaguá o primeiro grupo de mulheres negras. Eu digo nós, porque é um grupo de mulheres bastante interessantes. Um grupo de discussão cuja ideia inicial era só conversar com as mães, saber por que estava aquela confusão na escola - é uma época de criação dos Cieps. Mães, professoras, funcionárias de escola começam a discussão racial em Jacarepaguá. Coincide que o Rio de Janeiro estava organizando o Primeiro Encontro Estadual de Mulheres Negras. Essa vai ser a maior delegação dentro do encontro. A partir daí, começa a militância dentro do movimento de mulheres negras organizadas. A organização política das mulheres com as características de hoje surge em Guaranhuns, em Pernambuco. Vem com a ideia de interferir mais diretamente, de fazer com que as mulheres negras líderes se conheçam, tenham sua própria organização, seus próprios encontros, espaços. Guaranhuns é que dá essa percepção. Eu sempre gosto de dizer que hoje já tem instalado dentro do movimento negro um pouco da questão de gênero e dentro do feminista um pouco da questão racial, mas isso não foi sem dor para nenhum dos dois lados. Eu vivi bem esses dois lados, foi bastante difícil, eu acredito que ainda é bastante difícil essa incorporação. O Primeiro Encontro Nacional de Mulheres Negras (Enem) acontece em Valença, 1988. Foi um encontro muito bonito. Apesar das dificuldades, foi um encontro que reuniu 500 mulheres, 19 estados, se não me engano. Foi um encontro de grande representatividade. Nesse momento, a fala da mulher negra não estava pronta. A partir desse Encontro, criou-se a Comissão Nacional de Mulheres Negras. No Rio de Janeiro foram eleitas eu, Maria Lucia de Carvalho e Sandra Helena Bello. [...] No II Enem, em Salvador, 1991, já há um salto. Aí você já tem a fala específica de mulheres negras com imensa reflexão. Aboliu-se a ideia de representatividade e ficou estabelecido que todas as mulheres negras que quisessem participar do encontro poderiam fazê-lo. As mulheres negras começam a pesquisar, trabalhar, se preparar para estar no Encontro com uma fala de mulheres negras! Nesse encontro tivemos alguns problemas políticos na própria cidade, em Salvador. O pessoal rachou. O Encontro saiu com muitos problemas. Conseguimos garantir a continuidade da Comissão Nacional, a periodicidade do Encontro, algumas bandeiras de luta e que o próximo encontro seria no Distrito Federal. 
Os rachas e rupturas parecem não ser uma exclusividade do movimento de lésbicas, eu diria que, pela minha experiência em movimento social e político, é a natural dos espaços de poder e, sobre isso, Heliana Hemeterio fala em seu relato.

\begin{abstract}
Acho que esse comportamento entre lésbicas é o mesmo que acontece entre todas as mulheres. As mulheres são criadas para não confiarem umas nas outras. Estão sempre disputando "homens", sempre buscando maneiras de agradar, acolher e cuidar, ou seja, sempre tentando dar conta do papel imposto. A falta de autoestima fortalece todos esses sentimentos. Tenho percebido que, mediante alguns fatos, há total falta de solidariedade por parte das companheiras do movimento. Há três anos, uma separação entre lésbicas ocasionou verdadeiro linchamento político de uma delas, que tenta até hoje se reerguer. Esse assunto deveria ser tratado pelo menos, ao no meu entender, como um caso de relacionamento com problemas, inclusive de violência. Porém, além do julgamento do movimento, inclusive com a exclusão da entidade que as duas faziam parte pela articulação nacional que a mesma pertencia, sem sequer comunicar ou dar qualquer outro tipo de satisfação. Outro fato foi a atitude da vítima de violência física. Além de tomar as providências cabíveis, o que foi correto. Enviou e-mails para todas as redes, financiadores, representantes de governo. Um verdadeiro linchamento pessoal. Parece que as mágoas, dores vividas durante o casamento acabaram em um desejo de destruição da outra.
\end{abstract}

A partir da história vivenciada na Bahia, especificamente em Salvador pela Eide Paiva, ela também se recorda das rupturas do movimento na Bahia com reflexos nacionais nas organizações de lésbicas com a separação das ativistas Jane Pantel e Zora Yonara, companheiras e ativistas que atuavam juntas no GLB.

Quando o GLB (Grupo Lésbico da Bahia) chega, aí já chega na perspectiva da política pública, numa outra lógica de mercado, porque era um negócio. E a Jane fala, eu também tive a oportunidade de entrevistar a Jane, e ela fala claramente: "é um negócio interessante", por que ela era uma menina de periferia, uma menina que viu naquilo ali uma oportunidade de botar o seu nome no Google, que é uma expressão que ela usa. Ela já construiu uma história e que foi muito importante e foi mesmo. Pra mim, foi fundamental, por que se eu não tivesse encontrado o GLB eu continuaria lésbica, porque eu já era lésbica antes de encontrar o GLB, mas eu não teria esse reconhecimento da lesbianidade como um ato político, um ato de resistência. Então, pra mim foi muito importante, mas o GLB também não agregou, por que eu penso que assim era o paradigma da estrela, então o GLB tinha uma estrela, então ele nasceu a estrela, tá lá no boletim do GGB: "nasce uma estrela em 95". Então a estrela era Jane Pantel. Embora, ela tivesse a Zora Yonara, sua companheira, que foram as duas, né, embora tivesse um grupo e eu conhecia esse grupo. [...] Eu não tinha a opressão comum, eu não vivia, e eu só fui conhecer a opressão comum em 2006, quando eu fui ameaçada por que o que podia me ameaçar? Eu morava sozinha em Salvador, né, num bairro classe média burguês, sozinha, meu marido, que eu tinha, que eu tinha marido na época, estava com meus filhos no interior e eu fui estudar, tava estudando, então eu tinha uma vida no décimo andar, não tinha meu armário, 
era muito confortável e não em nada me ameaçava, né? Mas eu ouvia depoimentos de pessoas que perdiam a guarda dos filhos, mulheres que tinham filhos e perdiam a guarda dos filhos e viviam violências horríveis, e aquilo tudo eu não conhecia, eu tinha a escuta pra entender aquilo pra ser solidária e perceber a importância da solidariedade, pra quê? Pra existência lésbica. Então isso pra mim foi o GLB, e eu gosto de pensar nele como uma grande referência pra mim e, como isso, na época eu era estudante de Biblioteconomia, conhecia o acervo do GLB, um acervo maravilhoso, mas a gente não tinha acesso. Por que não tinha acesso? Por que eu era da universidade e havia uma desconfiança, assim essa desconfiança entre academia e militância era algo que até hoje eu não consigo compreender. Mas, existia e eu namorava, vivia, compartilhava a vida com uma menina também bibliotecária e a gente tinha um desejo muito de trabalhar aquele acervo, de dar inteligibilidade àquele acervo, mas não, sabe aquela coisa, deixa pra depois, deixa pra depois. Mas, a gente percebia que não tinha uma indisposição para um olhar de desconfiança por ser as lésbicas da academia, eu ainda era estudante, né? Nem era, mas já estava, já tinha minha autonomia, já trabalhava, era funcionária pública, então a questão de classe foi uma coisa que dificultou a confiança, embora Jane Pantel e Zora Yonara fossem minhas amigas. [...] E essa coisa do holofote, da estrela, por que só brilhava, só tinha visibilidade Jane Pantel, e Zora Yonara apagada do lado dela, o tempo todo isso. Embora todo mundo soubesse quem era Zora Yonara, a primeira baiana uma pessoa que era muito querida, todo mundo na Bahia gosta muito dela, um doce de menina. E Jane Patel tornou-se a pessoa odiada na Bahia, todo mundo tem uma referência muito negativa dela. E a referência negativa em função dela, do término da relação, quando o grupo acaba a história mal contada que ninguém sabe direito e ninguém quer saber também, por que envolve questões de casamento, de afetividade. E reitera essa ideia de que no casamento de lésbicas, as lésbicas acabam uma relação a cada grupo, mas na Bahia não acabou, por que a Jane Pantel, ela passou o legado para Palavra de Mulher Lésbica, que foi o primeiro grupo de lésbicas negras com a Valquíria Costa.

Beth Calvet inicia sua militância em 1987 com a fundação do movimento de familiares e amigos de presos e presas, com profissionais e psicólogos do Departamento do Sistema Penitenciário do Rio de Janeiro (Desipe). É fundadora da Astral (Associação de Travestis e Liberados), organização do Rio de Janeiro que atuava na defesa de pessoas travestis, transexuais e transgêneros. Nesse período, conheceu o movimento feminista por meio da professora Vanda Ferreira, e passou a militar no movimento negro, onde despertou sua atenção para as questões de lésbicas negras e, juntas, atuaram no Acorda Egresso, um movimento de ex-presidiárias que se transformou em ONG e iniciou-se em 1989, na Penitenciária Feminina Talavera Bruce (SCHUMAHER, 2003) .

Em dezembro de 1994, ela e mais cinco mulheres, entre elas Neusa das Dores, fundam o Centro de Documentação e Informação Coisa de Mulher (Cedoicom), e em 1995, com outras companheiras, cria o Coletivo de Lésbicas do Rio de Janeiro (Colerj). Organizou em 1996, com sua companheira, o I Senale, no Rio de Janeiro, e em sua homenagem o Coletivo 
de Lésbicas do Rio de Janeiro passou a ser chamado Coletivo de Lésbicas do Rio de Janeiro Elizabeth Calvet. Beth faleceu em 10 de setembro de 2001, aos 41 anos, de causa desconhecida.

Nesta minha experiência de ouvi-las com compromisso acadêmico, percebi o quanto, muitas vezes, não nos damos conta da importância de nossas ações ou da nossa importância como ativistas, e foi dessa forma que Yáskara se relatou militante, mesmo tendo afirmado não ser.

$\mathrm{Na}$ verdade eu não posso me julgar uma ativista, porque eu sempre fiquei assim escondida e depois tive uns probleminhas, eu tive que sair do Brasil, eu voltei algumas vezes, entre idas e vindas foram uns alguns dois, três anos, mas, quando eu voltei, eu tive um caso de muitos anos e eu não era uma ativista, na verdade eu comecei a aparecer em 2002, 2003, na época em que fizeram o Senale em São Paulo que alguém me convidou, eu fui e dali eu comecei. Depois eu fui fazer uma coluna na revista $G$ Magazine e aí todo mundo me conhece por isso, mas eu não posso afirmar que eu seja realmente uma ativista, daquelas que sobe no palanque, que fala, uma Irina, por exemplo (risos).

Antes de continuar seu relato, confesso que neste momento debati com ela as muitas formas de ativismo, inclusive a dela enquanto lésbica feminista, cigana e muçulmana e que, ainda, nos anos de chumbo, lutou pela democracia. Mas seguindo, ela retoma.

Era mesmo um período triste, eu além de estudar na USP, já era complicado, fazia russo, uma língua comunista, e eu trabalhava para o Paul Monteli, dono da livraria francesa. Ele tinha uma editora que chamava Difusão Europeia do Livro, e eu traduzia alguns livros, como Sartre, que era amigo de Seu Monteli, eles estudaram juntos, e eu o recebia aqui no Brasil. Então eu estudava na USP, trabalhava para Seu Monteli, fazia russo, traduzia os livros Mastero e Sartre. Então eu era considerada bandida, terrorista. O que não era verdade, eu conhecia esse pessoal todo da luta, mas não era verdade. [...]

Já vivi momentos bastante constrangedores por ser lésbica e ainda sou perseguida pelo povo, povo cigano, povo roma. Eu acho que só me toleram porque eu ainda os represento em eventos importantes como este que ocorrerá em Brasília, ${ }^{26}$ promovido pela ONU, eu sou convidada e aí eu sou até importante. Uma coisa que eu gostaria de frisar é que no auge da perseguição, que eu era enxovalhada pelos próprios irmãos, né, vamos dizer assim, eu tive uma passagem muito interessante e eu quero deixar registrada, porque ela morreu recentemente. Eu nunca disse exatamente o quanto como eu queria dizer obrigada para ela, foi pouco, assim, ter dito obrigada, foi a Lurdinha. ${ }^{27}$ A Lurdinha numa dessas grandes reuniões que fizeram, foi na

26 Ocorrido em setembro de 2015 por ocasião da visita da relatora especial das Nações Unidas sobre Questões das Minorias, Rita Izsák, que reuniu ativistas ciganos de diversos países para tratar de uma agenda de direitos humanos para ciganas/os das Américas.

27 Conhecida como Lurdinha, militante lésbica, estudou Sociologia e Política na FESPSP e morreu em 14 de fevereiro de 2015, em um acidente automobilístico na Bahia. Lurdinha integrou a Liga Brasileira de Lésbicas, foi conselheira nacional de saúde e antes de falecer era coordenadora-geral de diversidade da Secretaria de 
Secretaria de Saúde, e ciganos do Brasil todo, inclusive ciganos do sertão da Paraíba, aquela coisa toda. E sabendo já que eles são extremamente homofóbicos, convidaram a Lurdinha para fazer uma palestra e ela foi de um brilhantismo absurdo. A ciganada não deu um pio, ficou todo mundo ouvindo, ouvindo e dali muitas coisas boas aconteceram. Eu passei a ser um pouco mais respeitada, se hoje eu não sou é por meia dúzia de malucas aí, mas tudo bem, elas não são representativas. Mas ela foi muito importante principalmente para os ciganos do Nordeste, pois lá no Nordeste, numa cidade do Nordeste, tem uma moça que se veste de homem, anda cavalo e é casada com uma outra cigana e tal, ela era injuriada e passou a ser mais respeitada. Então fica registrado aqui o meu muito obrigada a Lurdinha, valeu, ela realmente ajudou bastante.

Analisando ainda as intersecções, Heliana é ekedi, ${ }^{28}$ filha de Iansã, feita no santo, e reforça a intersecção de raça e religião de matriz africana com a sexualidade e, principalmente, como rede de sociabilidade e de troca de conhecimento.

Eu sou ekedi, sou de candomblé e só conhecia três gays que eram meus amigos e irmãos de santo.

Neusa das Dores reforça mais uma vez a importância da intersecção em sua militância lésbica, negra e feminista.

Nosso objetivo ao criar o Cedoicom era buscar o saber produzido, tão distante da maioria das mulheres negras, e devolvê-lo às mulheres negras utilizando linguagens mais adequadas, através de cassetes, cartilhas, seminários, cursos, palestras etc. [...] Projetos de capacitação profissional onde as mulheres aprendem eletricidade, elas são capazes de fazer toda a instalação elétrica de um prédio, consertos de eletrodomésticos, manutenção hidráulica e agora nós acrescentamos dois módulos, de chaveiro e de telefonia. Esse projeto é destinado a mulheres desempregadas, subempregadas, egressas do sistema penal e meninas em situação de risco. Temos um projeto dentro do sistema penal. [...] Temos também um projeto de assessoria a parlamentares e a outras ONGs. Por exemplo, a Lei 2.475, de 1996, que proíbe a discriminação de gays, lésbicas e travestis em estabelecimentos públicos e comercias foi uma iniciativa nossa em conjunto com a Comissão de Direitos Humanos da Alerj.

Nesse período em que lésbicas se organizavam no movimento de lésbicas e outros, despontava como forte e organizada a militância da ativista Rosely Roth, que não só empresta seu rosto, sua história, seu ativismo para marcar aquilo que hoje chamamos de visibilidade lésbica. Suas duas aparições no programa da apresentadora Hebe Camargo (1985 e 1986) são recordações que mantenho até hoje em minha memória, porque me mostraram que lesbianidade não era aquele senso comum da música do Chacrinha ou do ilustrado nos livros 
que li na época, como O Poço da Solidão ou, ainda, Queda para o Alto. ${ }^{29} \mathrm{Na}$ época, eu jogava basquete e, apesar de não imaginar minha orientação sexual, já marcavam em meu corpo minha identidade lésbica, que era sempre lembrada em agressões na escola, em casa quando meu irmão fazia questão de lembrar que eu era sapatão, porque jogava basquete e tinha o cabelo curto, sem nunca ter desejo por mulher ou homem naquela época.

E não só em mim, a presença da Rosely Roth na televisão foi referência, mas ela também aparece na fala de Carmen.

Essa menina foi a primeira lésbica pública que eu conheci. Ela se tornou pública depois da aparição no programa da Hebe Camargo. Conheci naquele famoso encontro de Bertioga, no Terceiro Encontro Latino Americano e Caribenho de Feministas que aconteceu em Bertioga, Rosely estava lá, queria organizar as lésbicas feministas que estavam nesse lugar, ela já era uma pessoa que tava no feminismo, uma lésbica e de outra etnia, rica, então uma pessoa que muito difícil de exercitar a lesbianidade dentro da sua família, dentro dos seus grupos de iguais, por que se não se discutia isso. E se já era difícil você discutir isso em lugares mais periféricos, onde a disciplina burguesa não alcançava, ela vivia dentro disso e vivia disso, né? E ela queria organizar as mulheres lésbicas que estavam dentro do Encontro Feminista, não conseguia, não, era muito difícil. Botava um cartazinho na parede convidando pra uma reunião, amanhã o cartazinho amanhecia rasgado, não tinha um lugar pra gente se encontrar, a organização do evento não dava, passava pra gente se encontrar. Os nossos encontros eram na beira da piscina, debaixo de uma sombra em uma árvore, não sei onde. Por que a gente não conseguia ter um lugar adequado pra isso, né? Essa menina foi uma pessoa que fez aquela, foi uma das protagonistas do famoso Movimento dos Ferro's Bar, ${ }^{30}$ né, ela tava fazendo planfletagem do grupo de lésbicas dela dentro do Ferro's Bar e foi expulsa, foi colocada pra rua. E, no outro dia, ela voltou com todas as amigas, tomaram o bar e ficou marcado com um dos grandes eventos de visibilidade do Movimento de Lésbicas no Brasil, foi essa tomada do Ferro's, né? Tudo isso era tão difícil na vida dessa pessoa que essa menina não segurou a onda e teve a sua saúde mental estourada, ela se atirou do alto de um edifício em uma determinada hora, por que ela não suportou mais a pressão familiar, a pressão do machismo, a pressão do feminismo que nos pressionava na época, né? Eu sou uma mulher lésbica que, antes de militar no movimento lésbico, eu militei no movimento feminista, então eu senti todo esse rechaço do movimento feminista. Realmente, isso era muito verdadeiro "sapatão aqui não, porque a gente não é mal amada, a gente não é contra homens, né, não odeia homens e vocês são as mal amadas e as que odeiam homens". Então não pode se misturar com a gente, né? Acontecia muito isso e essa pessoa foi uma das principais ilustradoras de toda essa coisa da organização de mulheres lésbicas na minha vida.

29 O Poço da Solidão, livro de Radclyffe Hall que conta a história de uma menina que foi registrada com nome masculino e se considerava invertida. Na época, ele foi proibido na Inglaterra por incentivar a lesbianidade, e foi liberado em 1948. Queda para o Alto, livro de Sandra Mara Herzer, depois conhecido como Anderson Herzer, quando assume sua identidade trans masculina e que conta no livro sua trajetória e dolorosa história de vida que culminou em suicídio.

30 Bar que era tradicional ponto de encontro de lésbicas na noite paulistana. 
Ainda sobre a participação da Rosely no programa da Hebe Camargo, Marisa Fernandes (2014) em seu artigo no livro Ditadura e homossexualidades relata a participação dela no programa exibido em 25 de maio de 1985, exibido ao vivo na TV Bandeirante, de grande audiência, em rede nacional. Rosely foi convidada para discutir um tema que ainda era tabu e que, por meio do programa, conseguiu tornar conhecido nacionalmente o GALF (Grupo Ação Lésbica Feminista) e divulgou por duas vezes a Caixa Postal do grupo, mostrou ainda o boletim ChanacomChana. Uma das participantes desse debate era a mãe de uma lésbica, que longamente expôs toda a sua homofobia contra as lésbicas, dando a Rosely a oportunidade a Rosely debater com ela.

Marisa Fernandes (2014) reforça que a repercussão da participação de Rosely no Programa da Hebe foi alvo de repressão da ditadura. A apresentadora Hebe recebeu uma carta do chefe do Serviço de Censura Federal de São Paulo, Sr. Dráusio Dornellas Coelho, que frisou:

[...] demonstrando não ter pulso e nem saber conduzir o tema enfocado, a apresentadora Hebe Camargo permitiu que seu programa se transformasse numa tribuna livre de aliciamento, indução e apologia do homossexualismo feminino. Assim colocado, solicito ao digníssimo diretor da conceituada rede, enérgicas providências junto à apresentadora e sua produção e que seja elevada a faixa etária do programa em referência, com gravação prévia.

A repercussão da participação de Rosely no programa também foi matéria no jornal Folha da Tarde, que publicou, por três dias consecutivos (30, 31/05 e $1^{\circ}$ de junho), reportagens sobre a censura e a repressão aplicadas à Hebe e seu programa de entrevistas, ao censor, a mãe homofóbica e a Rosely. A apresentadora Hebe Camargo revelou na entrevista sua indignação e descontentamento com o teor da carta, como ela afirmou: "imoral são os pactos de morte nas celas, feitas para denunciar as péssimas condições carcerárias e também as pessoas passarem fome" (FERNANDES, 2014).

E como recordou Carmen Luiz, o evento do Ferro's Bar é um marco na história do movimento de lésbicas não só porque teve como protagonismo as lésbicas no enfrentamento ao silêncio e à violência imposta pelo dono do bar, que não aceitava a distribuição da publicação ChanaComChana, mas também pelo fato de ter enfrentado a repressão imposta na época pela polícia paulista sob o comando do Delegado José Wilson Richetti.

$\mathrm{O}$ relato detalhado desse dia além de ser descrito pelas ativistas Marisa Fernandes e Miriam Martinho, também pode ser encontrado na página $27,1^{\circ}$ Caderno da Folha de São 
Paulo, ${ }^{31}$ publicado no dia 21 de agosto de 1983, que trago para este trabalho como forma de trazer à luz da história a visibilidade conquistada pelo movimento de lésbicas desde o princípio de sua organização.

A matéria foi escrita pelo jornalista Carlos Brickmann com o título "A noite em que as lésbicas invadiram seu próprio bar".

São 22h15, sexta-feira. Faz frio na rua Martinho Prado. Na calçada, um grupo de moças aguarda pacientemente o momento de entrar em ação. Rosely, a líder, anuncia que chegou a advogada. Está tudo pronto: a um sinal, as lésbicas invadem o Ferro's Bar. Houve alguma resistência, logo vencida. O porteiro, assim que começou a invasão, fechou as portas e segurou-as com o corpo. Dentro do bar, tumulto total: gritos de "entra, entra", tentativas inúteis de parlamentar com o porteiro, um discurso da vereadora Irede Cardoso que, doente, saiu de casa só para apoiar a manifestação. Alguém força a passagem, o porteiro empurra violentamente dois rapazes, enfia a mão no rosto da militante Vanda. De repente, cessa a resistência: alguém tirou o boné do porteiro e o atirou no meio das mesas. Enquanto, desesperado, o porteiro sai atrás do boné, completa-se a invasão. Estranho, muito estranho: se o Ferro's Bar é há mais de vinte anos o ponto de encontro preferido das lésbicas da cidade, por que elas precisaram invadi-lo? [...] A gota d'água viria no dia 23 de julho. As militantes do Grupo Ação Lésbica Feminista entraram no bar para vender seu jornal, que tem o sugestivo título de ChanacomChana - o leitor tem liberdade para imaginar o que quer dizer. No momento em que faziam o discurso de apresentação do jornal, foram postas para fora do bar. "O dono proibiu nossa entrada", informa Rosely. "Não proibi nada, nem a venda do jornal", rebate Aníbal, um dos sócios do Ferro's. "Só não quero tumulto. Ou então daqui a pouco vem gente querendo vender colchão aqui dentro. Não dá, não é?". Não era bem verdade; tanto a entrada das moças estava proibida que na noite da invasão o porteiro fechou-lhes a porta na cara. O fato, porém, é que colocá-las fora do bar por pouco não custou o rompimento definitivo do velho casamento entre as lésbicas e o Ferro's. [...] Roseli é uma morena bonita, alta, de 23 anos e grande capacidade de mobilização. Embora o movimento rejeite lideranças, ela encabeçou o protesto: "Nós sustentamos esse bar e temos o direito de vender nosso boletim", afirmou. "Se eles não recuarem, vamos boicotar o Ferros!". Foi tudo muito bem organizado: houve convites a Irede Cardoso, ao deputado Eduardo Matarazzo Suplicy (que lamentou não poder ir, pois estava de viagem marcada), à advogada Zulayê Cobra Ribeiro, da OAB, garantindo a cobertura de quem participasse do protesto; e contatos com grupos de homossexuais masculinos, entidades feministas, ativistas de direitos civis, todo esse pessoal que dá a vida para comparecer a um protesto e contribui para engrossar a manifestação. Juntar todo o grupo à porta do Ferro's levou mais de uma hora. Dentro, o clima era de tensão: nas mesas, lésbicas discutiam a validade ou não do protesto, o risco de se envolverem em confusões que as prejudicariam no emprego ou revelariam a verdade às famílias; no balcão, o proprietário dizia esperar com ansiedade o momento da invasão. "É propaganda, é bom, o nome do meu bar vai sair na Folha. E mais tarde as moças vão cair em si e ver que estavam erradas”. Mas o porteiro se mantinha alerta, pronto para fechar as portas no momento

31 Disponível em: <http://acervo.folha.uol.com.br/fsp/1983/08/21/2//4199396>. Acesso em: 16 jan. 2016. 
propício - manobra que só falhou porque lhe tiraram o boné. Depois da invasão, o happening: Rosely discursando em cima da mesa, grupos de lésbicas menos assumidas saindo de rosto coberto, medrosas de eventuais fotografias, a vereadora Irede Cardoso funcionando como mediadora. Um pouco atrás, o porteiro, já de boné, tentava sem êxito puxar briga com uma lésbica que o chamara de palhaço (não sabe do que escapou: a moça é boa de briga e trabalha na polícia). Gritaria geral, enquanto Irede parlamenta com o proprietário e Rosely. Irede pede silêncio, fala alto, acaba sendo atendida: "O dono do bar está dizendo que foi tudo um mal entendido, que ele ama as lésbicas, quer que venham aqui e vendam seu boletim em paz. Quer que conversem com o outro sócio, também, para acabar com todos os mal entendidos. Ele reconhece que vive de vocês. E viva a democracia!" Rosely ainda quer discutir, exige que o dono repita sua rendição em voz alta, Irede a acalma, ela discursa: "Ele só voltou atrás por causa de nossa força, de nossa união. A democracia neste bar só depende de nós!”. O clima já está relaxado, os garçons voltam a circular de mesa em mesa com cerveja bem gelada. E Aníbal, o proprietário, completa: "Podem vender o jornal. Mas para mim é de graça, tá?”.

Rosely Roth é uma daquelas figuras que foi importante até para seus pares, suas contemporâneas companheiras ativistas que, assim como Carmen, citam-na como referência, como fez Marisa Fernandes em sua entrevista e Miriam Martinho nos boletins e na Revista Um Outro Olhar que reforça sua importância e contribuição ao movimento.

A década de 1990 se caracteriza pela multiplicação de grupos de lésbicas e de ativistas lésbicas nos grupos mistos. Diversos grupos surgem, publicações e ativistas, como a fundação do CFL (Coletivo de Feministas Lésbicas), a Rede Um Outro Olhar, Movimento D'Ellas, Grupo Felipa de Souza, Grupo Lésbico da Bahia e Coisa de Mulher no Rio de Janeiro, que se destacam na sua atuação no movimento construindo dessa forma o I Senale (Seminário Nacional de Lésbicas), em 1996, no Rio de Janeiro. Posteriormente, esse seminário marca a data de 29 de agosto como o Dia Nacional da Visibilidade Lésbica, assim como é reconhecido o 19 de agosto como Dia do Orgulho Lésbico, devido à resistência lésbica feita no Ferro's Bar, já descrita neste texto.

Nesse período, na efervescência da recente volta da democracia ao país, da promulgação da Constituição Federal, as ativistas que já se organizavam anteriormente têm suas ações e sua militância mais fortalecida e organizada, como no relato de Neusa das Dores e de Heliana.

(Neusa) Em 1996, nós fizemos, com muito sucesso, o I Seminário Nacional de Lésbicas. Até aqui não havia tido nenhum encontro nacional de lésbicas. Foi de 29 de agosto a 1 de setembro. Foi um sucesso estrondoso. Foi tão grande que nesse encontro foi tirado o Dia Nacional da Visibilidade Lésbica que é o dia 29 de agosto. O Colerj é dirigido por negras, a prioridade é as mulheres negras, a discussão racial é forte, embora junte outros segmentos de mulheres. Fazemos oficinas, discussões, vídeos, grupos de autoajuda. 
Voltando a sua pergunta, como o I Seminário foi um grande sucesso e também com a velha ideia de fortalecer os outros estados, o II Seminário foi em Salvador, o III em Minas, esse trabalho ganhou corpo, cresceu. As mulheres que estavam organizando os encontros internacionais estavam sem lugar para fazer o V Encontro de Lésbicas Feministas da América Latina e do Caribe. Em princípio esse encontro deveria ser na República Dominicana, mas a situação de lésbicas é bastante complicada na América Latina como um todo. Então qual seria o país onde poderíamos colocar esse encontro de uma forma mais aberta? O Brasil surgiu como alternativa. Nós já tínhamos essa história de encontro de mulheres negras, de encontros de lésbicas, de pioneirismo. Perguntaram se nós aceitaríamos e loucamente aceitamos. Loucamente porque na época não tínhamos estrutura nenhuma, nem computador, nem telefone. E a história está ai. O Encontro reuniu cerca de 330 mulheres.

(Heliana) Em 1994 ou 95, a Neusa das Dores após sair da organização Criola (ONG de Mulheres Negras do Rio de Janeiro), da qual era fundadora, cria Coisa de Mulher, que tem como objetivo trabalhar as questões de fortalecimento da autoestima das lésbicas negras. Começo então a participar das reuniões e passo a constituir com a comissão de construção do I Seminário Nacional de Lésbicas que ocorreu em 1996. Durante esse evento é decidido que o dia 29 de agosto, seria o dia da Visibilidade Lésbica. O Cedoicom (Centro de Documentação e Informação Coisa de Mulher) a partir dos resultados do Senale, organiza o Colerj (Coletivo de Lésbicas do Rio de Janeiro). Eu já conhecia a Neusa que era minha companheira de militância no IPCN e era lésbica assumida. Aí meu contato com o movimento se dá a partir do Senale, quando as relações entre as lésbicas no movimento se dá as articulações.

Eu fazia parte do Colerj e participava das ações das lésbicas no Rio de Janeiro, sempre trazendo a discussão racial. Participei de todos outros seminários nacionais que ocorreram. [...] Em 1999, assumo a coordenação do Colerj, onde organizo agendas mensais com oficinas de vários temas, trazendo o feminismo como base para discussões. Neste período coordeno o Projeto Lésbicas e Saúde, também o I Seminário de Lésbicas da Região Sudeste, que dá origem a Revista Visibilidade Lésbica.

Durante o III Fórum Social Mundial, em Porto Alegre, em janeiro de 2003, em meio à realização do Planeta Arco-Íris, em uma Oficina de Visibilidade Lésbica, que contou com a participação de dezenas de mulheres lésbicas e bissexuais de vários estados do Brasil e com a presença de ativistas e não ativistas de outros países, foi construída a Liga Brasileira de Lésbicas (LBL), a primeira rede nacional de lésbicas e mulheres bissexuais no país, que possibilitou a discussão da necessidade de uma agenda lésbica no movimento LGBT. No ano seguinte, após divergências entre a condução da rede nacional é fundada a ABL (Articulação Brasileira de Lésbicas).

As articulações entre lésbicas, a partir da participação no FSM, especificamente no Planeta Arco-Íris, marcam mais uma vez esse processo de rupturas e rompimentos do movimento, que é reforçado na voz da Heliana. 
Em 2002, após participar do Planeta Arco-íris durante o Fórum Social Mundial, mediantes as divergências acadêmicas e políticas, saio do Colerj e vou fazer parte do quadro de militantes do Grupo Arco-íris de Direitos Humanos, o GAI, a convite de Cláudio Nascimento, presidente da instituição à época.

Esse ponto marca mais uma vez as rupturas do movimento de lésbicas entre a opção de aproximar a agenda lésbica ao movimento feminista e a de continuar atrelada à agenda LGBT. Almeida (2005), ao analisar essa trajetória, descreve o drama do movimento de lésbicas, pois apesar de manter sua especificidade e autonomia em relação aos movimentos LGBT e feministas, mantém, com tais atores, uma relação de dependência e sustentabilidade política, organizacional e financeira.

Este período é marcado por um novo momento ao movimento de lésbicas quando começam a se organizar em redes nacionais. Esse momento traz para o movimento um cenário diferente, com a interiorização do movimento, a quebra da hegemonia do Sudeste, a organização das lésbicas negras em rede com a realização do I Seminário Nacional de Lésbicas Negras, após a organização delas no VI Senale, em Recife/PE, em 2006, com a participação de aproximadamente 250 mulheres de todas as regiões do país, 22 estados e com uma forte presença de lésbicas das regiões Nordeste e Norte.

Durante os próximos anos, as lésbicas se organizam para participarem de conferências nacionais, a II Conferência Nacional da Mulher, em 2007, e a I Conferência Nacional LGBT, na época ainda chamada de GLBT em 2008.

As duas conferências trazem nos relatos das entrevistas marcas consideradas importantes e históricas, como reforça a Eide, a seguir, citando a atuação da ativista Valquíria Costa na II Conferência Nacional de Políticas para as Mulheres, e a Heliana, quando reforça que um dos fatos históricos do movimento foi a mudança da sigla de GLBT para LGBT, priorizando pela primeira vez a visibilidade lésbica.

Eu conheci Valquíria em 2007, na Conferência de Mulheres, e ela era a única lésbica assumida. Eu fazia, eu estava com as feministas também lésbicas, não muitas de nós, mas ninguém tinha, não tinha um posicionamento de lésbica, eram as feministas. E Valquíria foi aquela lésbica negra que tudo que se falava, tudo que se fazia era aquela pedindo a palavra, pedindo a inclusão das lésbicas. Se nos Anais da Conferência saiu a palavra lésbica em tudo, foi por que ela, com sua chatice, insistiu, colocou.

Esse processo de conferências e da organização das lésbicas em redes nacionais possibilitou a inclusão da representação do movimento LGBT no Conselho Nacional de 
Saúde, que teve em suas quatro representatividades, desde a primeira conquista do assento, na titularidade, a representatividade lésbica: Carmen Luiz (LBL, 2006 a 2009), Lurdinha Rodrigues (LBL, 2009 a 2012), Verônica Lourenço (LBL, 2012 a 2015) e Heliana Hemetério (ABGLT, 2015-2018).

Para dar voz a este processo de participação de lésbicas na construção da política de saúde da população LGBT, trago a voz de Verônica Lourenço, que sintetiza a atuação das lésbicas em parceria com as demais representatividades do movimento LGBT.

Quem me conhece sabe, mas eu fiz essas parcerias porque, do lugar onde eu estou, né, que é o Conselho Nacional de Saúde, pela Liga Brasileira de Lésbicas, mas representando a população de lésbicas, gays, travestis, transexuais, é minha obrigação fazer e eu não podia deixar de fazer, né? E aí, conseguir manter esse diálogo e conseguir ouvir esse retorno foi pra mim muito positivo, e depois eu falei é o mais importante a gente está se candidatando até pra fortalecer isso, porque assim a ABGLT esse ano, por exemplo, vai concorrer à vaga do Conselho, Rede Afro LGBT, a ArtGay, a Antra e a Rede Trans. Todas as redes podem concorrer a uma vaga, aí é uma cadeira composta por três representantes, um titular e dois suplentes, primeiro e segundo suplentes. Mas a vaga é da organização que estiver na titularidade, aí com os acordos você faz a coisa de compor com outros movimentos, mas, por exemplo, a LBL poderia ter dito assim que era o que, que foi o que o Léo Mendes usou inclusive pra querer envenenar a ABGLT e a Antra dizendo: "Olhe, elas não vão cumprir acordo, porque a vaga é da titularidade e vocês vão ver, quando terminar a eleição ela vai botar primeiro e segundo suplente ou então ela vai tirar um de vocês dois e vai botar um suplente". E pra surpresa, isso não aconteceu, a gente inclusive combinou rodízio entre a LBL e a Antra, e depois a própria Fernanda Benvenuty chegou pra mim e conversou como, desde 2012, o conselho elegeu como prioridade para trabalhar a saúde de travestis e transexuais. Então toda a reunião do Conselho Nacional de Saúde, o Ministério da Saúde financiava a ida da Fernanda, porque era fortalecimento dela, e aí quando chegou na época de rodízio, Fernanda veio conversar comigo e falou: "Olha, se a gente fizer o rodízio, a gente vai perder uma voz aqui. Porque você não vai estar, só vai estar eu pelo Conselho, então a gente se mantém da forma que tá, eu sempre tô vindo, o suplente tem direito a voz tanto quanto o titular, os nossos votos na hora de votar alguma coisa nunca teve divergência, né? Por conta da pauta que é maior." Então eu ficava muito tranquila, pois no momento de discussão eu saía e eu sabia que aquela coisa que estava sendo pautada, o voto seria o nosso voto, independente se quem votasse seria eu ou a Fernanda, então a gente conseguiu chegar a esse patamar.

A intensidade dos relatos descritos que dão sentidos e vozes as lésbicas me provocam a remontar as vivências de minha vida já inciadas neste trabalho.

Aos 13 anos, quando me descobria ao mundo político, a vontade de me envolver e sentir a política, comecei a perceber que as meninas me chamavam atenção, mas um despertar 
diferente, de admiração que não era igual com os meninos, mas que também me despertava afeto e interesse. Sem entender o que era essa admiração e interesse e tão pouco que poderia ser desejo e afeto, e ainda, o interesse pelos meninos que não prosperava, vivi minha adolescência diferente de muitas, mergulhada em utopismo no meu quarto.

Fui a segunda pessoa da minha família a cursar uma faculdade, me formei em fisioterapia, mas foi somente após a consolidação da minha carreira profissional que me voltei a vivenciar minha sexualidade, com 28 anos me envolvi sexualmente com uma mulher e foi o trampolim necessário para perceber minha lesbianidade. Logo em seguida, me apaixonei por algumas mulheres, um processo fácil e sem dor, contei a minha irmã que se encarregou, a minha revelia, mas para minha comodidade contar a toda a família e com isso, não conheci e nem senti o cheiro do armário.

Paralelamente, a medida que o meu sentir-me lésbica se fortalecia dentro de mim, minha veia militante desabrochou intensamente, me envolvi na defesa das famílias homoafetivas, na luta pelos direitos e pela promoção da saúde das mulheres lésbicas e bissexuais, no direito a corporalidade de travestis e transexuais e na militância LGBT nacional, em atividades de incidência política no Brasil e internacionalmente.

Filiei-me ao CFL e como relatado anteriormente pelas demais entrevistadas, também presenciei e vivenciei rachas e rupturas, vivenciei a saída de um grupo de ativistas, no qual me incluo, da Liga Brasileira de Lésbicas em São Paulo devido ao não entendimento das metodologias da rede e por isso, a minha militância lésbica foi se fortalecendo em São Paulo tão somente pelo CFL, até que o coletivo resolveu se filiar a ABGLT e então, pela Associação Nacional fundamos o Coletivo de Mulheres Feministas da ABGLT.

$\mathrm{Na}$ necessidade de fortalecer mas o movimento de lésbicas, me associei a ABL e representando São Paulo fortalecemos a rede nacional, sendo por ela que tive assento no Conselho Nacional de Combate a Discriminação e Promoção dos Direitos de LGBT, me tornando a primeira vice-presidenta e assumindo, interinamente a presidência até sua próxima eleição.

Ainda pelo CFL que tinha filiação na ILGA e na ILGALAC, organizamos a Conferência Mundial da ILGA em São Paulo e fui indicada para a suplência da representação lésbica da ILGA-LAC e da secretaria de mulheres da ILGA. 


\subsection{Sentidos da Cidadania e a Cidadania LGBT}

Neste ponto deste trabalho, o objetivo foi entender como a palavra cidadania mobilizou as ativistas Heliana, Marisa e Yáskara que, ao responder o roteiro de entrevista, possibilitaram a análise de discurso. Nesse contexto, as vozes lésbicas trouxeram ao texto os sentidos da cidadania, que refletem de forma diferente em cada uma delas, em determinados sentidos num contexto de reivindicação e resistência social que fundamenta a prática dos movimentos sociais, mas que fora sentido por esta pesquisadora em contexto bastante diverso daquele que percebi ao longo dos anos como ativista do movimento LGBT.

Além do conceito explorado no capítulo anterior, no sentido sociológico, a cidadania tem um sentido político que expressa a igualdade perante a lei, conquistada pelas grandes revoluções, e posteriormente reconhecida no mundo inteiro.

Assim, para entender o sentido que a palavra tem para as ativistas, o bloco três roteirizou a palavra cidadania para que pudessem explorar os sentidos e suas buscas.

Marisa Fernandes elaborou e aprofundou seu sentido a partir de sua vivência como ativista que lutou contra a ditadura e pela democracia.

Cidadania plena para todas brasileiras e todos brasileiros não existe não. $\mathrm{O}$ Brasil sempre foi um país dominado pela elite, inicialmente pela colonização portuguesa, que explorou e nos levou riquezas e trouxe a escravidão negra africana para este país, bem como dizimou indígenas, os obrigou ao catolicismo, impôs submissão; posteriormente já no século XIX, com o advento da República, os dois primeiros presidentes eram militares; passamos então para a política do café com leite, onde as elites cafeicultoras de São Paulo e agropecuária de Minas Gerais se sucediam na presidência. Sempre tivemos no centro do poder do país representantes da elite masculina, branca e heterossexual. Foi um país marcado por ditaduras civil e militar. É bom ressaltar que este último período da República brasileira é o que tem a democracia mais longa, nunca tivemos tanto tempo de democracia quanto temos hoje, e olha que ela está sob perigo, mais uma vez proveniente das classes dominantes e conservadoras. Em um país que tem essa trajetória histórica, não se pode dizer que há cidadania para todas e todos. Sempre houve excluídos pela cor, pela classe social, pela origem (imigrantes, por exemplo), pelo gênero, as mulheres que o digam o quanto, pela orientação sexual e identidade de gênero, há também os não cidadãos geracionais, portadores de deficiências físicas e mentais e tantos outros.

Heliana Hemeterio foi mais direta, mas de igual forma explora o sentido de cidadania plena no Brasil, como Marisa. 
Sim, há cidadania no Brasil, mas somente para alguns, especialmente para os homens e mulheres brancos e heterossexuais, de classe rica e média e principalmente que compactuem com valores que fortaleçam o status quo, da sociedade. Negros, negras LGBT, pessoas com deficiências, população de rua e outros segmentos considerados menores estão muito longe de possuírem cidadania.

Com sua vivência internacional e percepção de (não) cidadania cigana, Yáskara nos revela outros sentidos para a percepção da cidadania no Brasil.

O Brasil é um grande enigma, talvez seja um dos melhores países do mundo e a gente não saiba, é provável que sim, foi o que falei para o Sérgio Mamberti, quando estava no Ministério da Cultura, quando eu disse que eu ia mais falar, que eu ia reclamar do Brasil, mas depois que eu vi as oito ciganas, uma lá do leste europeu, outra não sei da onde, eu vi que o Brasil é o paraíso, mas não acho que há cidadania para todo mundo.

Ao aprofundar o sentido de cidadania para si, as ativistas foram ainda mais categóricas ao afirmar a cidadania como algo distante, ainda que com direitos alcançados, como relata Heliana.

Sim, apesar de mulher, negra e lésbica. Sou cidadã consciente de meus direitos. A partir de minha inserção na militância para garantia de direitos, percebi que minha luta seria sempre sair do lugar onde a sociedade me colocava e o lugar que eu deveria ocupar a partir de minha contribuição na construção dessa sociedade e como essa contribuição fortalecia a elite que me excluía principalmente por conta de minha raça e orientação sexual. A partir disso, começo a elaborar o meu lugar de "fala" nessa sociedade e me afirmar enquanto uma cidadã de direitos.

E Yáskara já vai ao cerne da questão quando afirma não ter cidadania:

Não, do jeito que eu queria ser não. Eu queria ter liberdade de subir num banco de praça e falar, falar o que eu acho. Eu não tô conseguindo falar no Facebook, lá você fala e vem uma enxurrada de pessoas doidas, com ódio, com raiva. Meu Facebook é sem graça, só tô falando de ciganos porque é meu projeto, mas não posso falar mais nada, e então eu me sinto uma cidadã cerceada.

E na esteira do sentir-se cidadã, Marisa Fernandes afirma:

Sou branca, posso votar, mas não me sinto cidadã no meu próprio país. Sou mulher e o machismo, a misoginia me esmaga todos os dias da minha vida. Sou lésbica e meus direitos não são plenos como os garantidos para as 
pessoas heterossexuais, sou discriminada por isso e vulnerável é minha cidadania, diariamente estou exposta a violações de todos os tipos. Agora sou idosa, e como toda essa geração até o meu salário de aposentada está em constante risco e somos colocadas de lado como algo já descartável seja pela precarização da saúde, seja pela falsa crença de que somos improdutivas, seja pela falta de políticas públicas dirigidas a esta população.

Nos relatos ainda é perceptível, como a democracia e o estágio atual do país, assim como o recrudescimento conservador e religioso, reflete-se nas vozes lésbicas. Marisa não deixou de frisar que a volta da democracia ao país foi a maior conquista neste período, ainda que imatura e ameaçada como está. A ativista Yáskara percebe também a democracia como um valor imprescindível para garantir seu status de cidadania e aponta para o crescimento da direita, que cerceia as liberdades, principalmente de expressão. Por outro lado, Heliana nos lembra de que os avanços obtidos para a construção da cidadania passaram por direitos conquistados pelas pessoas LGBT, como a união estável, o casamento civil entre pessoas do mesmo sexo, a adoção propiciada em decorrência deste e os direitos previdenciários.

As ativistas também apontam como entraves para mais avanços e um sentir pleno de cidadania para LGBT a mistura da fé e do poder, destacada por Heliana, o moralismo, o conservadorismo, a manutenção dos privilégios, a manutenção da norma/normalidade definida como poder para Marisa, e Yáskara finaliza afirmando que não há, de fato, mais avanços por causa da religião.

Nesta esteira de sentidos e buscas pela cidadania LGBT, diversas outras tão importantes ativistas foram essenciais para esta história aqui retratada. A construção do movimento de lésbicas que se inicia no final dos anos 70, que se entrelaça na luta e no enfrentamento à ditadura civil-militar, pelas liberdades civis e redemocratização do Brasil sobrevive até hoje por muitas vozes que ao longo destes 37 anos surgiram, desapareceram e resistiram.

Do processo de organização das redes nacionais de lésbicas, LBL, ABL, Rede de Lésbicas Negras, CANDACES, Rede Sapatá, o movimento ganha em representação e diversidade e o perfil das ativistas vai modificando ao longo da história dos SENALE, com a interiorização, a descentralização da representatividade sul-sudeste, a organização das lésbicas negras em redes próprias e os reflexos de suas demandas e força que se expressam a partir do VI SENALE em 2006 no Recife de forma sistemática e em rede. Desde então, as lésbicas negras assumem também as vozes do movimento de lésbicas e por meio de suas redes dialogam com a sociedade e o Estado. 
Este fato reforça as idas e vindas do movimento, visto que o primeiro SENALE é organizado pelo COLERJ que é majoritariamente formado por lésbicas negras e que tinha como uma das principais demandas a intersecção de raça, gênero e sexualidade.

Os efeitos cíclicos, do ir e vir, são percebidos por atores externos como rachas e rupturas que só reforçam ao longo desta história as transformações do movimento, visto que a medida que novas atrizes surgem, as tensões são necessárias para as acomodações destas agregações.

Isto se reforça na realização do VIII SENALE quando as demandas de lésbicas jovens e principalmente, de mulheres bissexuais mais uma vez rompe as estruturas do movimento de lésbica e com nova tensão, formalizam a necessidade de acolher suas especificidades e que se percebam representadas, com isso ao final do VIII SENALE que ocorreu em 2014 em Porto Alegre, a plenária final decidiu, não por consenso, mas por necessidade de se redefinir e agregar, que o IX encontro chamaria SENALESBI - Seminário Nacional de Lésbicas e Mulheres Bissexuais, programado em junho de 2016.

Estes sentidos e as diversidades identitárias dentro do movimento de lésbicas e mulheres bissexuais se relevaram ao longo da história, necessárias para a formatação do movimento que dão sentido na trajetória e no caminho das vozes lésbicas no Brasil. 


\section{CONSIDERAÇÕES FINAIS}

Ao finalizar este estudo, percebi que sua conclusão é apenas um retrato de um movimento e de vozes que o construíram, afinal muitas das histórias aqui descritas são partes de uma luta que se inicia quando muitas que hoje militam não eram nascidas, mas quando muitas de nós depositávamos nesses movimentos a esperança de um mundo melhor e livre.

Vivemos hoje um surto epistemológico de conservadorismo, um momento onde parte das mulheres que entrevistei reconhece nestes dias marcas ainda não cicatrizadas do passado e um ódio latente, como não visto nos anos de chumbo.

Escrever esta dissertação, em meio aos retrocessos, à violência editorial dos veículos de imprensa, à organização dos mercadores de fé, que usam do senso comum na sociedade brasileira para implantar no país uma cultura de ódio legitimada pela crença em um deus violento, julgador e condenador, foi uma das tarefas mais difíceis que exerci em meus dias de militância, mas que as vozes ouvidas me trouxeram alento e esperança.

A organização do movimento LGBT no Brasil, especialmente do movimento de lésbicas, dá-se a partir do final do regime de exceção e de violação de direitos, com o processo inicial da anistia em 1979, da assembleia constituinte e com a promulgação da Constituição Federal, a chamada constituição cidadã em 1988.

Apesar da promulgada Carta Cidadã, do compêndio de normas jurídicas estabelecidas, não se reconhece na Constituição Federal norma específica de proteção da cidadania LGBT, fato obtido somente em 2011, após decisão do STF que permite a união civil entre pessoas do mesmo sexo e que, em 2013, foi normatiza pelo Conselho Nacional de Justiça, por resolução, em casamento civil.

Ainda assim, não houve recuo por parte do movimento LGBT, tampouco pelo movimento de lésbicas que, com a organização cada vez mais forte e ampliada por redes nacionais, obteve junto a normativos de direitos das mulheres as suas demandas também reconhecidas, como acesso a saúde e participação social.

As escutar cada uma das entrevistadas, suas palavras trouxeram em mim um conflito entre os muitos caminhos que percorri e o desejo das mulheres, principalmente seus sentidos de cidadania. Ao buscar por caminhos, entendia que a hierarquização de direitos posta pelos normativos jurídicos e pela sociedade a mulheres e homens, homossexuais e heterossexuais, negros e brancos, entre outros, seria o ponto de encontro entre as vozes, mas encontrei outros pontos que se cruzaram na busca pela cidadania e seus sentidos, como o desejo de ser livre e 
de amar, a solidariedade feminina e a busca pela sobrevivência como marco de suas cidadanias, as conquistas e vitórias pessoais como sentido de vida e o silêncio como ética entre lésbicas para valorização de todas as demais ativistas que foram citadas. A cidadania é muito mais sentidos do que fato jurídico.

Esse achado me revelou outro sentido de cidadania, uma cidadania mais justa e mais humana, que não se ampara em marcos jurídicos, mas na ética e na solidariedade, na justiça e no afeto, no respeito e no reconhecimento de histórias de vidas de mulheres que ousaram amar, lutar e dar sentido às vidas de muitas que hoje se organizam dos centros para o interior, do Sudeste para o Norte, Nordeste, e nos sentidos de um poder que não se afirma pelas conquistas individuais, mas pelas conquistas de um movimento que optou pelo alinhamento feminista e pela busca de sua identidade como mulheres e feministas.

Esse retrato emoldurado é parte de um estudo que ainda persiste da necessidade de aprofundamento para se entender as escolhas, o que me pareceu, na maior parte das vezes, decisões mais subjetivas do que refletidas, mas que levaram, ao longo dos anos, o movimento de lésbicas, as interseccionalidades e as lutas feministas, como lutas pelas suas cidadanias.

As histórias ativistas dessas mulheres revelaram que suas lutas se concentraram na coletividade, nos diversos marcadores identitários que marcam seus corpos, na perspectiva de enfrentamento as opressões, não somente pelo exercício livre da sexualidade, da orientação sexual, das expressões de gênero, da raça, etnia, mas também do exercício de suas religiosidades.

Todas essas identidades marcadas e sentidas por elas construíram em suas histórias sentidos de cidadania que contribuíram para a busca da cidadania, principalmente, pela forma como o movimento se organizou e as lutas que travou.

Não por acaso, ativistas lésbicas estavam à frente da representação do movimento LGBT no Conselho Nacional de Saúde, no Conselho Nacional de Povos e Comunidades Tradicionais, na expressão majoritária do Conselho Nacional de Promoção dos Direitos de LGBT e na representação de espaços institucionais internacionais.

Digo isso porque os relatos ouvidos e que neste trabalho foram descritos revelam a percepção de uma luta maior, e que a participação das ativistas foi fundamental para as conquistas que fomentaram estes sentidos de cidadania.

Escrever esta dissertação é mais um capítulo importante na minha vida ativista, pois ao remontar as trajetórias aqui refletidas por meio das vozes lésbicas aqui refletidas foi possível resgatar a história de mulheres que ao longo do caminho foram minorizadas e 
desparecidas, porém suas vozes continuam presentes e fortes fortalecendo o sentido particular da memória que por vezes falha e se perde na transmissão geracional.

Assim sendo, este trabalho também contribui para o direito à memória e na costura do tecido social do ativismo de lésbicas e mulheres bissexuais, dando sentido e continuísmo ao movimento.

Concluo, ainda, que o movimento LGBT é um dos silenciadores das vozes lésbicas, e que a invisibilidade a nós, lésbicas, imposta pelo desejo do macho opressor é o fetiche patriarcal de uma sociedade que legitima o silêncio, a voz e a sexualidade de suas mulheres. 


\section{REFERÊNCIAS}

ALMEIDA, G. E. S. Da invisibilidade à vulnerabilidade: percurso do corpo lésbico na cena brasileira face à possibilidade da infecção por DST e Aids. 2005. Tese (Doutorado em Saúde Coletiva) - Instituto de Medicina Social, Universidade do Estado do Rio de Janeiro, Rio de Janeiro, 2005.

ALVES, L. Os direitos humanos na pós-modernidade. São Paulo: Perspectiva, 2005.

ARENDT, H. Origens do Totalitarismo. São Paulo, Companhia das Letras, 1989.

O que é política? Rio de Janeiro: Bertrand Brasil, 2002.

Compreender: ensaios. São Paulo: Companhia das Letras, 2008.

Entre o passado e o futuro. São Paulo: Perspectiva, 2009.

A condição humana. Rio de Janeiro: Forense Universitária, 2010.

BARDIN, L. Análise de conteúdo. Lisboa: Edições 70, 1977.

BARBALET, J. M. A cidadania. Lisboa: Estampa, 1989.

BERNARDO, T. O candomblé e o poder feminino. Revista de Estudos da Religião, n. 2, p. $1-21,2005$.

BEAUVOIR, S. O segundo sexo: Mitos e Fatos. São Paulo: Difusão Européia do Livro, 1949.

BOBBIO, N. A Era dos direitos. Rio de Janeiro: Editora Campus, 1999.

BORRILLO, D. Homofobia: história e crítica de um preconceito. Belo Horizonte: Autêntica, 2010.

BOTELHO, A.; SCHWARCZ, L. M. Cidadania, um projeto em construção: minorias, justiça e direitos. São Paulo: Claro Enigma, 2012.

BRANDÃO, L. C. Os movimentos sociais e a Assembleia Nacional Constituinte de 19871988: entre a política institucional e a participação popular. 2011. Dissertação (Mestrado em Sociologia) - Programa de Pós Graduação em Sociologia, Universidade de São Paulo, São Paulo, 2011.

CICONELLO, A. A participação social como processo de consolidação da democracia no Brasil. In: OXFAM International. From poverty to power: how active citizens and effective states can change the world. United King, 2008. Disponível em: <http://www.oxfam.org/em/policy/from-poverty-to-power>. Acesso em: 28 abr. 2013, às $14 \mathrm{~h} 10$.

CRENSHAW, Kimberlé. Documento para encontro de especialistas em aspectos da discriminação racial relativos ao gênero. Revista de Estudos Feministas, Volume 10. $\mathrm{N}^{\circ} 1$. UFSC, Florianópolis, 2002.

COMPARATO, F. Fundamentos dos direitos humanos. Disponível em: <www.iea.usp.br/artigos>. Acesso em: 5 jan. 2013, às $13 \mathrm{~h} 30$.

COUTINHO, C. N. Contra a corrente: ensaios sobre a democracia e o socialismo. São Paulo: Cortez, 2000. 
DAGNINO, E. Sociedade civil, participação e cidadania: de que estamos falando? Disponível em: <http://biblioteca.clacso.edu.ar/subida/Venezuela/facesucv/uploads/20120723 055520/Dagnino.pdf. Acesso em: $1^{\circ}$ maio 2013, às 19h.

FACCHINI, R. Sopa de letrinhas? Movimento homossexual e produção de identidades coletivas nos anos 90: um estudo a partir da cidade de São Paulo. 2000. Dissertação (Mestrado em Antropologia Social) - Instituto de Filosofia e Ciências Humanas, Universidade Estadual de Campinas, Campinas, 2000.

. Mulheres, (homos) sexualidade e diferenças: uma reflexão sobre políticas públicas segmentadas. In: Reunião Brasileira de Antropologia, 26., 2008, Porto Seguro. Anais... Porto Seguro: Abant, 2008.

FERNANDES, F. B. M. A agenda anti-homofobia na educação brasileira (2003-2010). 2011. Tese (Doutorado em Ciências Humanas) - Programa de Pós-Graduação Interdisciplinar em Ciências Humanas, Universidade Federal de Santa Catarina, Florianópolis, 2011.

FERNANDES, M. Lésbicas e ditadura militar: Uma luta contra a opressão e por liberdade. In: GREEN, J. QUINALHA, R. Ditadura e homossexualidades: Repressão, resistência e a busca da verdade. EDUSCAR: São Carlos, 2014.

GIL, A. C. Métodos e técnicas de pesquisa social. São Paulo: Atlas, 2005.

GOHN, M. G. O protagonismo da sociedade civil: movimentos sociais, ONGs e redes solidárias. 2. ed. São Paulo: Cortez, 2008.

. Movimentos sociais na contemporaneidade. Revista Brasileira de Educação, v. 16, n. 47, maio-ago. 2011.

GOMES, S. O impacto das regras de organização do processo legislativo no comportamento dos parlamentares: um estudo de caso da Assembleia Nacional Constituinte (1987-1988). DADOS - Revista de Ciências Sociais, Rio de Janeiro, v. 49, n. 1, p. 193-224, 2006.

GRAMSCI, A. Concepção dialética da história. Rio de Janeiro: Civilização Brasileira, 1978.

GREEN, J. N.; MALUF, S. W. (Org.). Cadernos AEL: homossexualidade, sociedade, movimento e lutas. Campinas: Unicamp/IFCH/AEL, 2003. (v. 10, n. 18/19).

GUIMARÃES, A. S. A. Desigualdade e diversidade: os sentidos contrários da ação. In: Cidadania, um projeto em construção: minorias, justiça e direitos. São Paulo: Claro Enigma, 2012

HABERMAS, J. The Concept of Human Dignity and the realistic Utopia of human rights. Metaphilosophy, 41: 464-480. Extraído de em 19/10/2013.

HERRERA FLORES, J. A (re)invenção dos direitos humanos. Florianópolis: Fundação Boiteux, 2009.

HOLANDA, S. B. Raízes do Brasil. São Paulo: Companhia das Letras, 1995.

HOWES, Robert. João Antônio Mascarenhas (1927-1998): pioneiro do ativismo homossexual no Brasil. Cad. AEL, v.10, n.18/19, p.289-311, 2003.

KIRCHNER, A. R. Significando as formas de infecção e a relação com a gestão do cuidado a pessoa com HIV/aids. 2014. Dissertação (Mestrado em Enfermagem) - Programa de Pós-Graduação em Enfermagem, Universidade Federal de Santa Catarina, Florianópolis, 2014.

LIRA, R. Meta(na)morfoses lésbicas em Cassandra Rios. Revista Estudos Feministas: Florianópolis, v. 21, n. 1, p. 129-141, abr. 2013. Disponível em: 
<https://periodicos.ufsc.br/index.php/ref/article/view/S0104-026X2013000100007>. Acesso em: 18 nov. 2015, às $23 \mathrm{~h} 40$.

LOPES, M. A. S. Revista Ártemis, v. 4, jun. 2006. Disponível em: $<$ http://periodicos.ufpb.br/ojs/index.php/artemis/issu

e/view/222/showToc>. Acesso em: 5 nov. 2014, às 22h30.

MARCELINO, D. et al. Parlamentares na constituinte de 1987/88: uma contribuição à solução do "enigma do Centrão". Revista Política Hoje, v. 18, n. 2, 2009.

MINAYO, M. C. S. et al. (Org.). Pesquisa social: teoria, método e criatividade. 8.ed. Petrópolis: Vozes, 1994.

MIRANDA, M. B. Homens e Mulheres: A isonomia conquistada. São Roque: Revista Eletrônica Direito, Justiça e Cidadana, v.2, n.1, 2011.

MOTT, L. Lesbianismo no Brasil. Porto Alegre: Mercado Aberto, 1987.

NAVARRO. T. S. O normal e o "abjeto": a heterossexualidade compulsória e o destino biológico das mulheres. Disponível em: <http://www.labrys.net.br/labrys6/lesb/anahita.htm\#_edn1>. Acesso em: 16 jan. 2016.

NOGUEIRA, Nadia. Lota de Macedo Soares e Elizabeth Bishop: amores e desencontros no Rio dos anos 50 e 60. 2005. Tese (Doutoradoem História) - Departamento de História, Instituto de Filosofia e Ciências Humanas, Universidade de Campinas, Campinas, 2005.

PARKER, Richard G. Corpos, prazeres e paixões: a cultura sexual no Brasil contemporâneo. São Paulo: Best Seller, 1991.

PARKER, R.; HERDT. G.; CARBALLO, M. Cultura Sexual, transmissão do HIV e pesquisas sobre AIDS. In: AIDS. Pesquisa Social e educação. São Paulo, Rio de Janeiro: HUCITEC, ABRASCO, 1995.

PIOVEZAN, F. Ações afirmativas da perspectiva dos direitos humanos. Cadernos de Pesquisa, v. 35, n. 124, p. 43-55, jan./abr. 2005.

RICH, A. Compulsory Heterosexuality and Lesbian Existence. In: GELP, B C.; GELP, A. (Ed.). Adrienne Rich's poetry and prose. New York/London: W.W. Norton \& Company, 1993.

ROSSI, L. et al. (Org.). Guia de Prevenção das DST/Aids e Cidadania para Homossexuais. Brasília: Ministério da Saúde, 2002.

REIMÃO, S. Repressão e resistência: censura a livros na ditadura militar. 2011. Tese (Livre docência) - Escola de Artes Ciências e Humanidades, Universidade de São Paulo, São Paulo, 2011.

SAFFIOTI, H. I. B. Gênero, patriarcado, violência. São Paulo: Perseu Abramo, 2004.

SEDGWICK, E. K. A epistemologia do armário. Cadernos Pagu, Campinas, n. 28, p. 19-54, jan.-jun. 2007.

SEGATO, R. L. La nación y sus otros: raza, etnicidad y diversidad religiosa em tiempos de políticas de la identidad. Buenos Aires: Prometeo Libros, 2007.

SCHUMAHER, S. Um rio de mulheres: a participação das fluminenses na história do Estado do Rio de Janeiro. Rio de Janeiro: REDEH, 2003.

SIMÕES, J.; FACCHINI, R. Na trilha do arco-íris: do movimento homossexual ao LGBT. São Paulo: Perseu Abramo, 2009. 
SOUZA, J. et al. (Org.). Democracia hoje: novos desafios para a teoria democrática contemporânea. Brasília: Editora UnB, 2001.

Souza, Jessé. A construção social da subcidadania: para uma sociologia política da modernidade periférica. Belo Horizonte: Editora UFMG, 2006

TERRA, J.; PRADO, A. Contra-hegemonia: direitos humanos da população LGBT diante dos discursos jurídicos heteropatriarcais. Revista Gênero \& Direito, Paraíba, n. 1, 2014.

TILLY. C. Durable Inequality.California: University of California Press, 1999

TRIVIÑOS, A. N. S. Introdução à pesquisa em ciências sociais: a pesquisa qualitativa em educação: o positivismo, a fenomenologia, o marxismo. São Paulo: Atlas, 1987.

WALZER, M. Ensaio sobre desobediência, guerra e cidadania. Rio de Janeiro: Zahar, 1975.

WITTIG, M. Ninguém masce mulher. Disponível em: <https://we.riseup.net/sapafem/ningu\%C3\%A9m-nasce-mulher-monique-wittig>. Acesso em: 12 jan. 2016. 


\section{ANEXOS}

\section{ANEXO 1}

\section{Mulheres Violentadas}

"Enquanto um grande número de policiais tem sido mobilizado para reprimir manifestações estudantis, greves de operários, bancários, etc., a população é deixada indefesa diante da crescente onda de violência que atinge o país."

A violência sexual tornou-se cotidiana e as mulheres são suas principais vítimas. Estamos sendo arrastadas, espancadas, esfaqueadas e forçadas as mais dolorosas e humilhantes práticas sexuais por homens que ficam impunes inclusive em casos de morte.

As mulheres violentadas que abrem inquérito são submetidas a um vergonhoso exame pericial e mesmo quando os indícios provam o estupro, ainda assim, a polícia mostra-se omissa. Além disso, durante o transcorrer do processo e do julgamento, todo tipo de calúnia será usado contra a vítima, na tentativa geralmente bem sucedida de inocentar o criminoso.

O sistema machista e corrupto não protege a mulher. A lei protege o estuprador.

Mulheres de 6 a 60 anos são consideradas sedutoras, perversas e imorais sem o menor direito ao respeito dos homens. Quando isso vai acabar.

Nós mulheres brasileiras exigimos justiça.

Queremos uma resposta efetiva e concreta.

Queremos a revisão do Código Penal em relação ao estupro.

Queremos o fim da impunidade para os violentadores.

Queremos nossa dignidade física e moral asseguradas.

Precisamos acabar com o silêncio existente e denunciar os criminosos. Neste sentido conclamamos as mulheres violentadas a procurarem as associações interessadas nesses casos e que as ajudarão a lutar por seus direitos.

Anote e passe para suas amigas. 


\section{ANEXO 2 \\ MANIFESTO DO COLETIVO DE MULHERES FEMINISTAS DA ABGLT}

Nos dias 25 a 27 de abril de 2008, as mulheres lésbicas, bissexuais e transexuais presentes e reunidas na cidade do Rio de Janeiro para a realização do Seminário II Fortalecendo, Articulando e Informando Mulheres Lésbicas, Bissexuais e Transexuais percebemos a necessidade de construir uma nova opção política.

Estamos em um novo momento político da história de nossa entidade nacional. Nos últimos anos, o movimento LGBT vem amadurecendo e temos superado alguns desafios importantes, sobretudo no funcionamento e representatividade da ABGLT.

Esse novo momento permitiu, por exemplo, a recente adesão de dezenas de organizações a nossa Instituição, não só novos grupos, mas alguns com trajetória historicamente consolidada.

Contudo, restam desafios importantes. Um deles é garantir a incorporação do feminismo no cotidiano, nas formulações e nas prioridades da ABGLT. É preciso garantir a participação efetiva e os espaços de atuação das mulheres lésbicas, bissexuais e transexuais.

\section{Porque construir uma nova rede?}

Nós mulheres participantes do II Fortalecendo propomos a nossa reorganização dentro dos espaços políticos e representativos da nossa organização nacional, pois entendemos que estamos num momento onde se faz necessário uma rediscussão sobre a organização do movimento LGBT no Brasil e neste processo se faz necessário um projeto feminista para a nossa entidade.

A ABGLT é reconhecidamente a maior rede LGBT da América Latina, portanto, não obstante a isso, nós mulheres da ABGLT tensionamos a legitimidade de sermos também a maior rede de mulheres do movimento LGBT.

Concomitantemente, uma vitória especial foi o início do projeto SOMOSLÉS, em que pela primeira vez, capacitamos, de maneira nacional, simultânea e articulada, centenas de novas ativistas.

\section{Nova forma de organização interna:}

As signatárias deste texto e outras militantes com as quais vimos dialogando, entendemos ser prioritário impulsionar a organização das mulheres na ABGLT. Isso, para nós, deve ser feito de forma compatível com o novo momento político.

\section{Com isso, estamos neste manifesto criando, lançando e formalizando o COLETIVO DE MULHERESDA ABGLT.}

Reconhecemos a ABGLT como a principal e maior organização nacional do movimento LGBT brasileiro. E dentro dessa perspectiva, acreditamos que o Coletivo de Mulheres da ABGLT cumprirá um papel de grande importância.

\section{Apresentação do COLETIVO DE MULHERES DAABGLT:}

\section{Missão:}

Somos o Coletivo de Mulheres Feministas da ABGLT que visa garantir o combate a todas as formas de opressão, discriminação e violência, bem como o enfrentamento ao machismo, racismo e homofobia.

\section{Visão:}

Ser a maior rede unificada de mulheres feministas do movimento LGBT do Brasil.

\section{Valores:}

1. Horizontalidade;

2. Ética e Transparência;

3. Respeito;

4. Compromisso com a missão;

5. Enfrentamento ao machismo, racismo e a homofobia;

6. Visibilidade geracional; 
7. Respeito à autonomia aos Direitos Sexuais e Reprodutivos; e

8. Laicidade.

\section{Objetivos:}

1. Visibilizar as mulheres da ABGLT;

2. Garantir espaços políticos de representatividade nacional, controle social e valorização das mulheres da ABGLT, garantindo a equidade de gênero;

3. Fortalecer a legitimidade da ABGLT como representante do conjunto do movimento LGBT brasileiro, inclusive fazendo-se representar pelas diversas mulheres do Coletivo nos espaços nacionais de articulação política, controle social, conselhos, etc.;

4. Impulsionar a organização interna das mulheres na ABGLT, sua comunicação, articulação, capacidade de formulação e intervenção externa;

5. Fortalecer as organizações de mulheres que compõem o Coletivo;

6. Fortalecer as mulheres em organizações mistas, respeitando a representatividade, combatendo o machismo institucional;

7. Participar e influenciar nos processos de negociação nas matérias de direitos humanos e antidiscriminação por orientação sexual e identidade e expressão de gênero na ABGLT, no cenário nacional e em qualquer instância internacional perante as quais possamos ter uma posição das mulheres lésbicas, bissexuais e transexuais brasileiras sobre essas matérias;

8. Articular e capacitar ativistas lésbicas, bissexuais e transexuais na apresentação de projetos e captação de recursos junto aos órgãos governamentais, para ações de combate ao machismo, racismo, sexismo, misoginia, adultismo, homofobia e para a promoção da cidadania das mulheres;

9. Organizar a participação das mulheres da ABGLT nos processos decisórios da Instituição. Neste contexto, urge credenciar as mulheres lésbicas, bissexuais e transexuais da ABGLT como interlocutoras no governo federal.

\section{Metas:}

1. Ter uma mulher do coletivo como presidenta no próximo mandato da ABGLT;

2. Horizontalizar os processos decisórios;

3. Lutar pela equidade de gênero na ABGLT e afiliadas;

4. Filiar até 2010 na ABGLT, no mínimo, mais 20 (vinte) organizações de mulheres lésbicas, bissexuais e transexuais;

5. Enfrentar e combater o machismo dentro da ABGLT e suas afiliadas;

6. Reformular/adequar o Estatuto da ABGLT à missão do coletivo de mulheres;

7. Mapear e fortalecer os grupos de mulheres lésbicas, bissexuais e transexuais na ABGLT até 2010.

Plano de Ação:

(correlacionadas numericamente as metas)

1. Garantir que a indicação seja do Coletivo, bem como garantir uma maior representatividade de mulheres no congresso da ABGLT.

Ação:

1.1. Criar cotas para participação de mulheres afiliadas nos congressos da ABGLT;

1.2. Cumprir o compromisso de indicar uma representante legitimada pelo Coletivo com discussão previa e acumulada em espaço específico, virtual e pactuado previamente nos congressos. 
2. Garantir que as decisões tomadas pelas representações de mulheres da ABGLT sejam decididas pelas mulheres do Coletivo, a fim de garantir o compromisso de horizontalidade e representatividade.

Ação:

2.1. Criar uma lista virtual para comunicação das mulheres do Coletivo;

2.2. Buscar financiamentos para realização de um encontro nacional anual do Coletivo de Mulheres da ABGLT;

2.3. Realizar revisão estatutária da ABGLT;

2.4. Redesenhar o organograma institucional da ABGLT propiciando um formato horizontal.

3. Entender a definição de equidade, resgatando historicamente a desigualdade de gênero na nossa organização e sociedade.

Ação:

3.1. Formalizar representatividades políticas garantindo o recorte de gênero com equidade;

3.2. Impulsionar e apoiar uma candidatura de mulher para o próximo mandato da nossa organização;

3.3. Criar uma campanha de enfretamento e combate ao machismo institucional para a ABGLT e suas afiliadas/parceiras;

3.4. Realizar um Seminário com a temática de feminismos;

3.5. Garantir que os projetos da ABGLT tenham em suas coordenações mulheres e que as indicações sejam do coletivo.

4. Facilitar mecanismos de filiação/parceria.

Ação:

4.1. Impulsionar e apoiar a execução do SOMOS LÉS/ASTRAL TOP em todo território nacional, buscando a sua imediata realização;

4.2. Interiozar as ações do SOMOS LÉS/ASTRAL TOP no Brasil;

4.3. Ampliar o número de capacitandas alcançadas pelo projeto;

4.4. Buscar multirrecursos para execução do projeto;

4.5. Publicizar os resultados alcançados pelos SOMOS LÉS/ASTRAL TOP;

4.6. Incorporar o SOMOS LÉS/ASTRAL TOP como projeto da ABGLT;

4.7. Garantir que os projetos SOMOSLÉS seja executado por organizações afiliadas de mulheres ou por organizações onde mulheres estejam na coordenação e tenham autonomia.

5. Enfrentar e combater o machismo dentro da ABGLT e suas afiliadas.

Ação:

5.1. Criar uma campanha de enfretamento e combate ao machismo institucional para a ABGLT e suas afiliadas/parceiras;

5.2. Realizar um Seminário com a temática de feminismos;

5.3. Apoiar e encampar as campanhas do movimento feminista

6. Adequar o Estatuto a necessidade de um projeto feminista.

Ação: 
6.1. Aprovar no próximo Congresso da ABGLT a reforma estatutária adequando a missão do coletivo e seus valores;

7. Identificar as mulheres da ABGLT.

Ação:

7.1. Realizar um levantamento das mulheres nos grupos mistos afiliados/parceiros;

7.2. Realizar um mapeamento dos grupos exclusivos de mulheres da ABGLT.

Estamos convencidas de que temos legitimidade, representatividade, construção histórica e força política para nos tornamos a rede referenciada no cenário nacional.

Ademais, gostaríamos de finalizar com um texto apresentado na plenária durante a construção do nosso Coletivo que reflete nossos sentimentos expressados na construção do que pode parecer utopia, mas que tornaremos realidade na construção de uma sociedade mais justa, de paz e sem machismo, racismo e homofobia.

"Fortalecendo...

Trago nas mãos vazias

Uma multidão de sonhos... Sonhos de um construir coletivo,

Cujo resultado

Será um outro mundo!

Trago no peito um coração,

Que pulsa desejo intenso

De transformação...

Sei pouco, mas acredito

No processo de desconstruir

Tudo que nos ata, nos prende,

Nos viola e aprisiona.

Sou mulher!

E meu EU grita!...

Querendo transformação

Eis-me então me fortalecendo

Eis-me então na ânsia

De articular

E entre iguais,

Construir... Desconstruir... Reconstruir...

Trago em mim um espírito faminto

Quero e preciso fartar-me

De cada troca, de cada (in)formação,

De cada outro coração que pulsa,

No mesmo "ritmo",

No mesmo desejo que o meu.

Parto diferente...

Com mais ânsia... mais fome!

Mas com um sonho realizado:

A Certeza de não estar só!

De ser um coletivo...

De ser muitas...

E seguir fortalecendo! ...

(Escrito por Prika, expressado no II Fortalecendo, 26/04/2008).

Mulheres que assinam este documento:
1. Adriana Simone da Silva
2. $\quad$ Alana Gilmara Sousa Freitas
3. Alessandra Guerra
4. Alessia R. Moura 
5. Ana Carla Lemos

6. Ana Paula Theodoro

7. Azimar Orlow

8. Carla Machado

9. Célia Fernandes

10. Celize Azevedo

11. Claudia Aparecida dos Santos Alcântara

12. Cléo Dumas

13. Daniela Souza de Lima

14. Deborah Tavares

15. Denise de Carvalho

16. Denise Limeira

17. Eva Verginia da Silva

18. Evy Ferreira da Silva

19. Fernanda Monteiro

20. Gisele Ramos Coelho

21. Hedi Costa de Oliveira

22. Iara Viana Mouco

23. Irina Bacci

24. Jaqueline S. De Andrade

25. Jéssica Andrade C. Macedo

26. Julha Faustino Damião

27. Juliana Carvalho

28. Kellyane de Nazaré Vasconcellos de Oliveira

29. Lucélia Dias Macedo

30. Luciana Silva

31. Lucineide Ramos de Aragão

32. Luriana Cohen

33. M.Yáskara Guelpa

34. Márcia Cabral

35. Marilene Neres dos Santos

36. Marisa Fernandes

37. Martha Idalina Vieira de Vasconcelos

38. Monique Hofstein Ferreira

39. Nádia Nogueira

40. Priscila Galvão

41. Priscila Garcia Silva

42. Roge Durans

43. Sandra Torres

44. Selma Maria da Costa

45. Sirlene Cândido

46. Vera Couto

47. Yone Lindgren 


\author{
ANEXO 3 \\ NATIONS UNIES \\ HAUT HAUT COMMISSARIAT AUX \\ DROITS DE L'HOMME
}

NOTA SOBRE A $19^{\circ}$ SESSÃO DO CONSELHO DE DIREITOS HUMANOS DA ONU

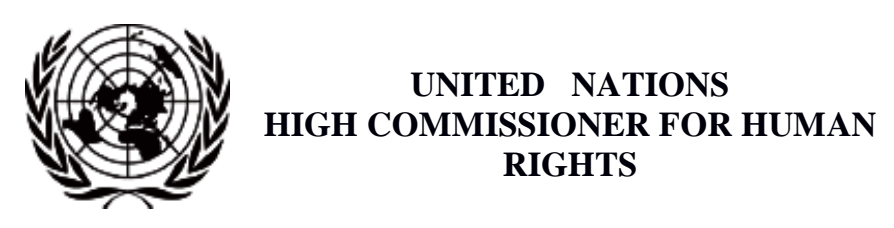

19th session of the Human Rights Council

\author{
Ending Violence and Discrimination \\ Based on Sexual Orientation and Gender Identity
}

Palais des Nations, Geneva

CONCEPT NOTE

\title{
Topic
}

The application of international human rights law to address incidents of violence, discriminatory laws and discriminatory practices against individuals based on their sexual orientation and gender identity.

\section{Date and venue}

Wednesday 7 March 2012, 12:00-15:00, Room XX, Palais des Nations

\section{Mandate and background}

In its resolution 17/19, the Human Rights Council expressed "grave concern" at acts of violence and discrimination in all regions of the world committed against individuals because of their sexual orientation and gender identity, and requested the High Commissioner for Human Rights to commission a study to "document discriminatory laws and practices and acts of violence against individuals based on their sexual orientation and gender identity, in all regions of the world, and how human rights law can be used to end violence and related human rights violations based on sexual orientation and gender identity." By the same resolution, the Council decided to convene a panel discussion during its $19^{\text {th }}$ session, informed by the High Commissioner's study.

\section{Focus and objectives}

The focus of the panel will be on the range of human rights violations to which individuals are susceptible on the basis of their sexual orientation and gender identity and the options available to States and to the Human Rights Council in order to address these violations. The objective will be to facilitate constructive, informed and transparent dialogue on the issue of discriminatory laws and practices and acts of violence against individuals based on sexual orientation and gender identity and generate greater agreement among States on the way forward.

Panelists will be invited to discuss the findings and recommendations of the report of the High Commissioner on violence and discrimination based on sexual orientation and gender 
identity (document ref. A/HRC/19/41). The panel is an opportunity for States to share their national experiences and examples of good practice, and to consider how the Human Rights Council, as the United Nations' peak intergovernmental body responsible for human rights worldwide, can ensure that in future it is kept adequately informed about and able to respond effectively to human rights violations based on sexual orientation and gender identity.

\section{Speakers and panelists}

Welcome address: HE Laura Dupuy Lasserre, President of the Human Rights Council

Message from Mr. Ban Ki-moon, United Nations Secretary-General (TBC)

Opening statement: Ms. Navi Pillay, High Commissioner for Human Rights

Moderation: HE Abdul Minty, Permanent Representative of the Republic of South Africa

Panel:

- Irina Karla Bacci (Brazil): Vice-President, National Council for LGBT Persons, Brazil

- Laurence Helfer (USA): Co-Director, Center for International and Comparative Law, Duke University, USA

- Hina Jilani (Pakistan): chair, Human Rights Commission of Pakistan; former Special Representative of the Secretary-General on human rights defenders

- Hans Ytterberg (Sweden): Chairperson of the Council of Europe Expert Committee on Discrimination on Grounds of Sexual Orientation and Gender Identity

- Additional panelist - to be confirmed

\section{Format}

The panel will adopt an interactive format, with no presentation other than the opening statement, which will lay the ground for discussion and define the scope of the theme. The moderator will animate a live discussion by asking a different question to each panelist, who will be given a 5 to 7 minute slot to answer the question. This method will facilitate targeting the discussions on specific issues related to violence and discrimination on grounds of sexual orientation and gender identity, formulated around salient questions to which panelists are invited to respond based on their expertise and experience.

There will be two sequences of about 30 minutes each during which each of the five panelists will answer the questions asked. The first round of questions will be on "the range and prevalence of violence and discrimination based on sexual orientation and gender identity", the second on "the application of international human rights law and implications for States at the national level and for the Human Rights Council." This will be followed by 45 minutes of interaction with the floor with comments and questions from Member States and Observers, to which the panelists will reply.

Member States and Observers are encouraged to formulate their statements in terms of questions and sharing of experience in order to stimulate a constructive debate. The interactive discussion will be followed by concluding remarks by the moderator. 


\section{Outcome}

The discussion will gather ideas on practical ways to strengthen protection of the human rights of individuals at risk of violence and discrimination on the basis of their sexual orientation or gender identity. It will identify concrete challenges and ways to overcome them through sharing of national experience and good practices. It will generate ideas and agreement on possible avenues to integrate information on human rights violations based on sexual orientation and gender identity into the work of the Human Rights Council and its mechanisms.

\section{Background documents}

- Human Rights Council resolution 17/19 "Human rights, sexual orientation and gender identity," A/HRC/RES/17/19 (2011)

- Report of the High Commissioner for Human Rights "Study on discriminatory laws and practices and acts of violence against individuals based on their sexual orientation and gender identity," A/HRC/19/41 (2011) 


\title{
ANEXO 4 \\ DISCURSO REALIZADO NO PAINEL DISCRIMINAÇÃO E VIOLÊNCIA BASEADO EM ORIENTAÇÃO SEXUAL DA $1^{\circ}$ SESSÃO DO CONSELHO DE DIREITOS HUMANOS DA ONU
}

\author{
Senhora Presidente do Conselho de Direitos Humanos, \\ Senhora Alta Comissariada para os Direitos Humanos, \\ Senhoras e Senhores Embaixadores, \\ Senhoras e Senhores painelistas,
}

Senhoras e Senhores,

Tenho a honra de dirigir-me a este Conselho como ativista de direitos humanos, representante da sociedade civil neste painel para compartilhar nossas lutas pelos direitos humanos de lésbicas, gays, bissexuais, pessoas transexuais, travestis, transgêneros e intersexuais, que ao longo da minha fala denominarei LGBTI.

Sou brasileira e entendo que a importância de meu país no atual cenário mundial me trouxe para este painel, mas quero não só falar dos nossos avanços, mas também das violações dos direitos de LGBTI.

Agradeço o convite do governo da África do Sul, que promoveu a resolução 17/19 em junho de 2011 e também do Escritório do Alto Comissariado para os Direitos Humanos da ONU para estar neste importante e primeiro Painel partilhando minhas experiências e principalmente, expressar a minha solidariedade com todas e todos aqueles cujos os direitos humanos são violados por sua orientação sexual e identidade de gênero do sul ao norte do Equador, mas em particular para a comunidade LGBTI dos países do SUL.

Minha apresentação não se resumirá na violência, discriminação e violações de direitos humanos no Brasil, mas em todos os estados.

A declaração universal dos direitos humanos declara que todas as pessoas humanas nascem livres e iguais em dignidade e em direitos. Dotados de razão e de consciência, devem agir uns para com os outros em espírito de fraternidade, ainda relata que os seres humanos podem invocar os direitos e as liberdades proclamados na presente Declaração, sem distinção alguma, nomeadamente de raça, de cor, de sexo, de língua, de religião, de opinião política ou outra, de origem nacional ou social, de fortuna, de nascimento ou de qualquer outra situação. Além disso, não será feita nenhuma distinção fundada no estatuto político, jurídico ou internacional do país ou do território da naturalidade da pessoa, seja esse país ou território independente, sob tutela, autônomo ou sujeito a alguma limitação de soberania. E principalmente, que todo indivíduo tem direito à vida, à liberdade e à segurança pessoal.

Sendo assim, é importante dizer que as violações de direitos humanos de LGBTI estão garantidas em nossa declaração e por isso, toda e qualquer violência promovida a população LGBTI é uma violação de direitos humanos, uma afronta a declaração universal e a todos os estados membros das nações unidas. 
No relatório anual sobre homofobia estatal, a ILGA - Associação Internacional de Lésbicas, gays, bissexuais, pessoas transexuais e intersexos, observamos que há ainda no mundo, 76 países que possuem algum tipo de lei discriminatória que criminaliza as relações sexuais consentidas entre adultos do mesmo sexo, sendo cinco deles com pena de morte. Essa realidade persiste continuar ainda que esse conselho em 2011, soberanamente reconheça como violações de direitos humanos as violências baseadas em orientação sexual e identidade de gênero e condenas esses atos para os seus estados membros.

Mesmo nos países, onde os governos atuam com políticas de proteção de direitos humanos LGBTI, ainda se nota uma grande violência, o que revela que a luta pelos direitos humanos de LGBTI não se resume somente na implantação de políticas governamentais, mas também na incidência de mudanças de paradigmas culturais de toda sociedade.

O relatório do Alto Comissariado para os Direitos Humanos da ONU listou uma série de violações, discriminação e violência baseadas em orientação sexual e identidade de gênero e eu mesma já vivi situações de violências porque minha orientação sexual é diferente da norma dominante, a heterossexualidade. O relatório lista uma série de violações baseados em orientação e identidade de gênero oriundos de todas as regiões e quero aqui destacar algumas dessas violações vividas por pessoas LGBTI.

Não é possível listar essas violações, senão começando pelas baseadas em identidade de gênero, o relatório do Alto Comissariado documentou uma lista extensa de violações sofridas por pessoas transexuais e transgêneros, bem como assassinatos baseado na identidade de gênero.

A violência nos países do hemisfério sul se assemelha para essa população, os obstáculos para o reconhecimento legal da sua identidade de gênero e consequentemente, da sua cidadania promovem uma série de violações desde sua aceitação pela família, nas escolas, no mercado de trabalho.

Em meu país, o Brasil, transexuais, travestis e transgêneros vivem a margem da sociedade, vivem nas esquinas noturnas das cidades, porque foram expulsas do convívio familiar, das escolas e com isso, não conseguem no trabalho formal, seu sustento e essa realidade é corroborada pela maioria dos países da América Latina.

$\mathrm{Na}$ maioria dos casos de assassinatos que envolvem transexuais, travestis e transgêneros, os requintes de crueldade é marca dos crimes, o que demonstra o quanto essa população é submetida a tortura e tratamento degradante.

Em recente denúncia feita por uma ONG no Brasil, travestis e transexuais eram leiloadas por presos evangélicos em troca de favores. Também em meu país, câmaras de segurança gravaram no ano de 2011, dez assassinatos de travestis nas diversas cidades brasileiras, sendo que na maioria dos casos, a vítima levou mais de 10 tiros.

Pesquisa realizada pelo Centro Latino-Americano em Sexualidade e Direitos Humanos em parceria com a Universidade Nacional da Colômbia denota que travestis e transexuais são os mais marginalizadas da oferta de trabalho, aqueles com níveis mais baixos de educação e maiores taxas de abandono escolar. De acordo com um diagnóstico realizado pela pesquisa, 
realizada em Bogotá, a maioria das travestis não têm relações jurídicas contratuais e renda estão abaixo do salário mínimo.

Como em outros países latino-americanos, na Colômbia, os travestis têm grande dificuldade em se estabelecer em um bairro ou uma vila, sendo vítimas de deslocamento forçado. Outros padrões de restrição de uso da terra e do espaço público refere-se à coerção social que impedem de se mover livremente em todas as áreas das cidades onde vivem e não tem acesso a lugares de comércio e lazer. Também são expulsos ou impedidos a sua admissão, que restringem o seu direito à habitação, trabalho e de trânsito, tendo como opção única áreas onde a prostituição é praticada.

Em uma carta aberta, a Aliança Internacional menciona a morte do jovem transexual Cheo, vitimado por uma facada no peito. O corpo da vítima foi encontrado na Colônia Almeida de Tegucigalpa, Honduras.

De acordo com a Europa Transgender, entre janeiro e junho de 2010 foram relatados nos meios de comunicação 93 assassinatos de pessoas trans no mundo, 74 casos ocorreram na América Latina. Estudos sobre as características destes crimes de ódio, mostram que há um "modelo" de perseguição regional e global de violência e intimidação contra pessoas transgêneros.

Outra preocupação é que em países como El Salvador, México, Peru, Colômbia, Haiti e Caribe anglófono, os casos de perseguição e violência aumentou e os assassinatos.

Dados oficiais do Brasil coletados pelo Disk Direitos Humanos da Secretaria de Direitos Humanos e a Central de Atendimento da Mulher da Secretaria de Políticas da Mulher, ambas da Presidência da República revelam que a população LGBTI é que mais sofre violação no Brasil, sendo que esses dados se referem somente ao ano de 2011 quando foi implantado o módulo de denuncia para LGBTI, representando 77,5\% das denúncias recebidas num total de 5952 violações.

Sobre assassinatos, pesquisa realizada pela Secretaria de Direitos Humanos da Presidência da República no Brasil mostra que em 2011 houveram 261 homicídios. Os dados revelam que travestis e transexuais somam 24,5\% dos casos, $29 \%$ de lésbicas e mulheres bissexuais e 40,5 \% de gays e homens bissexuais. A violência psicológica é a mais relatada, seguida de discriminação, violência física, violência sexual, violência institucional, tortura e outros tratamentos cruéis, entre outros.

Em relação a violência contra lésbicas e mulheres bissexuais, a secretaria de lésbicas da ILGA-LAC (Associação Internacional de Lésbicas, Gays, Bissexuais, Transexuais e Intersexos para América Latina) contabiliza cerca de 13 mortes na região, sendo que as características são muitos similares, em maioria são jovens.

O governo do Equador tem realizado esforços para fechar as clínicas de cura contra homossexuais, ainda assim grupos LGBTI do país estimam que hoje existam mais de 200 clínicas que prometem acabar com a homossexualidade. $\mathrm{O}$ caso mais marcante foi da lésbica Paola Ziritt de 28 anos que ficou dois anos internada em um desses centros, onde sofreu abusos - inclusive sexuais - insultos e tortura, como ficar algemada, permanecer dias sem comer e levar surras. Os guardas da clínica chegaram a jogar urina e água gelada nela. A mãe 
dela que a internou, pois acreditava em cura para o homossexualidade e só tirou a filha da clínica quando recebeu uma carta secreta de Ziritt.

No continente africano, a violência contra lésbicas também é bastante grande, a prática de estupro corretivo na África do Sul ganhou repercussão mundial pela mídia no caso da lésbica Millicent Gaika que foi atada, estrangulada, torturada e estuprada durante 5 horas por um homem que dizia estar "curando-a" do lesbianismo. Por pouco não sobrevive. Infelizmente Millicent não é a única, este crime horrendo é recorrente na África do Sul, onde lésbicas vivem aterrorizadas com ameaças de ataques.

Os jovens Samuel Brinton (americano) e Gustavo Campos (brasileiro) tem em comum a violência que sofreram de seus familiares. Samuel Briton foi submetido a tortura pelo seu pai que é missionário da Igreja Batista, o queimou, espancou e deu choques com correntes elétricas. Já Gustavo Campos, sofreu espancamento e enforcamento pelo seu irmão mais velho que é pastor de igreja evangélica. Casos assim são costumeiramente relatados por organizações não governamentais. O caso de Samuel ficou conhecido através do projeto I'm from Driftwood nos EUA e do Gustavo Campos foi denunciado pelo próprio jovem nas redes sociais e acolhido pelo centro de referência de combate a homofobia de Belo Horizonte, capital do Estado Minas Gerais no Brasil.

É importante dizer que nas últimas décadas, representantes do alto nível da ONU, citações em relatórios especiais, entre outros organismos regionais de direitos humanos reconheceram plenamente que os diversos sistemas internacionais de direitos humanos devem ser aplicados em violações de direitos baseados em orientação sexual e identidade de gênero. O Secretário Geral da ONU Ban Ki-Moon, pediu um fim às leis em todo o mundo que criminalizam a homossexualidade, sublinhando a necessidade de prestar urgente atenção aos direitos LGBTI durante as comemorações que marcaram o Dia Internacional dos Direitos Humanos. E ainda, reforçou que a Declaração Universal dos Direitos Humanos, adotada pela ONU na Assembleia Geral em 10 de dezembro de 1948, "não é chamado de declaração parcial dos direitos humanos e nem uma declaração as vezes de direitos humanos, é a declaração universal, garantindo todos os direitos aos seres humanos, principio básico dos direitos humanos, sem exceção".

Em evento realizado nos EUA, Ban Ki-Moon ainda disse que muitas vezes pensamos que o assédio homofóbico como um problema específico para ambientes escolares e para a adolescência. Mas as raízes estão mais profundas, pois esse assédio vigora em atitudes nocivas na sociedade em geral, às vezes encorajadas por figuras públicas e leis discriminatórias, além de práticas sancionadas pelas autoridades do Estado. Combater este problema é um desafio comum. Nós todos temos um papel, seja como pais, familiares, professores, vizinhos, líderes comunitários, jornalistas, figuras religiosas ou funcionários públicos. Mas é também, para os Estados, uma questão de obrigação legal. Pelos direitos humanos internacionais, todos os Estados devem tomar as medidas necessárias para proteger as pessoas - todas as pessoas - da violência e da discriminação, incluindo aquelas motivadas pela orientação sexual e identidade de gênero.

Em 29 de janeiro desse ano, o secretário Ban Ki-moon, afirmou que as Nações africanas devem parar de tratar homossexuais como cidadãos de segunda classe, ou mesmo criminosos. A afirmação foi feita durante a reunião dos líderes africanos na capital da Etiópia. 
A Comissão da ONU contra Tortura, Observação Geral No 2 de 2008 relatou que os Estados membros (da Convenção contra Tortura) devem garantir, no que diz respeito às obrigações estabelecidas pela Convenção, que suas leis sejam aplicadas, na prática, a todas as pessoas independentemente de orientação sexual (ou) identidade de gênero.

A Alta Comissária de Direitos Humanos, Navi Pillay, declara que leis que criminalizam a homossexualidade são uma grave ameaça aos direitos fundamentais de lésbicas, gays, bissexual e trans, expondo-os ao risco de prisões, detenções e, em alguns casos, torturas e execuções. Geralmente, sanções criminais vêm acompanhadas de grande quantidade de outras medidas discriminatórias que afetam o acesso a uma gama enorme de direitos - civis, políticos, econômicos, sociais e culturais. Nós também sabemos que a criminalização perpetua estigmas e contribui para um ambiente de homofobia, intolerância e violência.

O Diretor Executivo da UNAIDS, Michel Sidibé, em 16 de Maio de 2010, pediu a todos os governos que tomem medidas para eliminar o estigma e a discriminação enfrentados pelas populações de homens que fazem sexo com homens, de lésbicas e de trans. Os governos também devem criar ambientes sociais e legais que assegurem o respeito aos direitos humanos e permitam o acesso universal à prevenção do HIV e ao seu tratamento, atenção e apoio.

O parecer do Relator Especial da ONU para liberdade de religião e crença, 7 de Fevereiro de 2008, diz que não há hierarquia nas motivações da discriminação.

Diante das opiniões acima,gostaria de falar sobre os ganhos e as experiências bem sucedidas na América Latina. Quero lembrar aqui que na minha região, países como a Argentina, Uruguai, Brasil, Colômbia o casamento civil entre pessoas adultas do mesmo sexo é permitido e na cidade do México, capital do México também é permitido. Outras leis de promoção da cidadania de LGBTI são discutidas na região.

No Brasil muitos ganhos foram conquistados desde 2006, primeiramente com a criação do Programa Brasil Sem Homofobia, depois com a convocação inédita no mundo da I Conferência Nacional de Políticas Públicas e Promoção da Cidadania LGBT, cujo os resultados criaram o Plano Nacional de Promoção da Cidadania de LGBT. Também no âmbito brasileiro, como resultado da primeira conferência criou-se a política nacional de saúde da população LGBT, o decreto do então Presidente Lula que institui o Dia Nacional de Combate a Homofobia em 17 de Maio, a criação da coordenadoria nacional LGBT na estrutura da Secretaria de Direitos Humanos da Presidência da República, a instituição e posse do Conselho Nacional LGBT no qual sou presidente e recentemente, a realização da II Conferência Nacional LGBT.

Quero destacar que apesar desses ganhos, a vida de pessoas LGBTI em nossa região ainda é bastante violenta e graves são as violações, o que demonstra a necessidade de investimento em sistema de proteção internacional, bem como em mudanças de paradigmas culturais nas sociedades para que pessoas com orientação sexual e identidade de gênero fora da norma dominante, a heterossexualidade, possam viver livre da coerção, discriminação e violência.

Nesse sentido, é importante destacar que no Brasil, os assassinatos aumentaram em níveis alarmantes contra lésbicas, gays, bissexuais, travestis e transexuais perpetuado muitas vezes situações semelhantes para os crimes de ódio. O Brasil é o país com o maior número de assassinatos de travestis e transexuais em todo o mundo. Embora, os dados oficiais recentes 
ainda sejam subnotificados, pode-se argumentar que os crimes com base na orientação sexual e identidade gênero aumentou $113 \%$ nos últimos anos, baseados nos dados levantados pelo Grupo Gay da Bahia. Muitos desses crimes foram marcados por crueldade, incluindo o uso de armas de fogo, facas, espancamentos, tortura e castração.

Paralelamente, recentemente tem havido um crescimento na circulação e difusão de discursos de ódio contra as pessoas LGBTI. Tais declarações, vindas principalmente dos grupos de dogmatismo religioso ou extremismo, são transmitidas nos meios de comunicação, incluindo rádio e redes de televisão de concessão pública. Os dados oficiais têm um volume considerável de denúncias de violência contra a comunidade LGBTI, incluindo a violência psicológica, num montante de $44 \%$ do total gerado pela divulgação do discurso de ódio do extremismo religioso dogmático.

Em relação a este obstáculo, eu gostaria de compartilhar com todas e todos, que eu sou uma pessoa profundamente religiosa. Eu pertenço a uma comunidade religiosa afro-brasileira, de matrizes africanas. Eu tenho ido a todos os ritos necessários para cumprir minhas obrigações espirituais e sigo rigorosamente as regras definidas para orientar o meu caminho espiritual. Talvez seja importante dizer que ao longo de todos esses anos de meu compromisso espiritual, eu nunca fui discriminada ou excluída da minha comunidade religiosa. Esta minha experiência pessoal indica que o domínio religioso é plural e que este multivocalidade é um dom da diversidade que está a ser avaliado e melhorado pelas comunidades de direitos humanos, mas também os Estados e instituições interestatais comprometidas com o respeito, a promoção, a proteção e indivisibilidade dos direitos humanos.

Por fim, quero finalizar usando as palavras de um dos maiores líderes religiosos de meu país, cujo falecimento provocou grande comoção nacional, Chico Xavier.

"A gente pode morar numa casa mais ou menos, morar numa rua mais ou menos, morar uma cidade mais ou menos, e até ter um governo mais ou menos. A gente pode olhar em volta e sentir que tudo está mais ou menos Tudo bem... O que a gente não pode mesmo, nunca, de jeito nenhum, é amar mais ou menos".

Obrigada! 


\title{
ANEXO 5 \\ TERMO DE CONSENTIMENTO
}

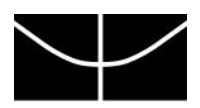 \\ UnB \\ UNIVERSIDADE DE BRASÍLIA \\ CENTRO DE ESTUDOS AVANÇADOS MULTIDISCIPLINARES \\ PÓS-GRADUAÇÃO EM DIREITOS HUMANOS E CIDADANIA \\ MESTRADO INTERDISCIPLINAR EM DIREITOS HUMANOS E CIDADANIA
}

\section{TERMO DE CONSENTIMENTO LIVRE E ESCLARECIDO}

Declaro, por meio desse termo que concordei em ser entrevistada ou participar da pesquisa de campo referente à dissertação de mestrado intitulada "VOZES LÉSBICAS NO BRASIL: A BUSCA E OS SENTIDOS DA CIDADANIA LGBT", da pesquisadora Irina Karla Bacci, orientada pela Prof $^{a}$ Dr $^{a}$ Rita Laura Segato.

Afirmo que aceitei participar por minha própria vontade, sem receber qualquer incentivo financeiro ou ter qualquer ônus e com a finalidade exclusiva de colaborar para o sucesso da pesquisa. Fui informada dos objetivos estritamente acadêmicos do estudo e também esclarecida de que os usos e informações por mim oferecidas estão submetidos às normas éticas destinadas à pesquisa envolvendo seres humanos.

Minha colaboração se dará de forma identificada, visto que o objetivo do trabalho pretende dar voz às ativistas lésbicas, por meio de entrevista. $\mathrm{O}$ acesso e a análise dos dados coletados far-se-ão apenas pela pesquisadora. Fui ainda informada de que posso me retirar desta pesquisa a qualquer momento, sem prejuízo para meu acompanhamento ou sofrer quaisquer sanções ou constrangimentos.

Atesto recebimento de uma cópia assinada deste Termo de Consentimento Livre e Esclarecido.

/__ /2015

Assinatura da participante:

Assinatura da pesquisadora: 


\section{ROTEIRO DE ENTREVISTA}

\section{BLOCO 1}

\section{TRAJETÓRIA DE VIDA}

Vamos abordar primeiro a sua trajetória de vida:

- Data/ano de nascimento?

- Onde nasceu?

- Formação acadêmica ou escolar?

- Ocupações que já teve e /ou tem?

- Onde mora atualmente?

- Segundo a classificação do IBGE para raça/cor, como você se identifica?

- Qual sua orientação sexual? E identidade de gênero?

- Como se identifica?

- Composição familiar atual?

- Como foi o processo de descoberta da sua sexualidade?

- Como era ser "lésbica" ou a da forma como se identifica quando percebeu que sua sexualidade era diferente?

- Você procurou redes de sociabilidade?

- Você teve apoio familiar ou se não teve, conte-me como foi. 


\section{BLOCO 2}

\section{TRAJETÓRIA DE ATIVISMO}

$\underline{\text { Neste bloco, vamos abordar sua trajetória de ativismo ou ativismos }}$

- De forma livre, conte-me quando, como e de que forma se deu o primeiro contato com o ativismo?

- O seu contato com o movimento LGBT (homossexual) se deu neste momento ou iniciou seu ativismo com outro tipo de movimento? Qual? E me descreva de que maneira? Foi sozinha? Ou convidada? Por quem?

- Se o seu primeiro contato com o ativismo não foi o LGBT (homossexual), quando você entrou em contato com o movimento e como?

- Convidada (por quem) ou sozinha?

- Quando e como se deu seu contato com o movimento de lésbicas?

- Qual era a sua participação no movimento de lésbicas e ou LGBT?

- Qual e como era ou é a relação do movimento de lésbicas com o movimento LGBT?

- Se você optou por um grupo exclusivamente de lésbicas, conte-me por quê.

- Na sua percepção, como se organizam as lésbicas?

- Quando lemos relatos da história do movimento de lésbicas, geralmente eles acompanham informações de rupturas, rompimentos e subdivisões, o que pode me contar sobre isso?

- Na sua história ativista estes fatos ocorreram? Você ouviu falar? Participou de algum? Ou soube de algo?

- Quais os grupos em que você atuou? E integrou alguma rede? Quais?

- Conte-me um pouco da sua trajetória do ativismo que você acha importante.

- Quais grupos de lésbicas e/ou ativistas você considera importante para o movimento e as conquistas?

- E para sua vida?

- E qual grupo ou rede LGBT você acredita desenvolver um trabalho importante para as conquistas?

- E para sua vida? 
- Quais ativistas, grupos e/ou redes conheceu ou ouviu falar de atuação na sua região e no país?

- Quais ativistas, grupos de lésbicas ou redes que conheceu, conhece de atuação na sua região e no país?

- Poderia citar outras ativistas lésbicas com as quais militou ou milita e considera importante para a memória política do movimento? E por quê? Poderia relacioná-las à época em que elas militaram ou militam?

- Na sua opinião, há preconceito dentro do movimento? Fale um pouco disso.

- Você considera o movimento LGBT um movimento político? Por quê?

- Você considera o movimento de lésbicas um movimento político? Por quê?

- Qual a importância do movimento LGBT e de lésbicas para a democracia no Brasil?

- Você participa de outros grupos políticos? Qual ou quais?

- Quais os principais fatos históricos do movimento de lésbicas no Brasil?

- O que mais você gostaria de me contar sobre seu ativismo e sobre ativismo no Brasil?

\section{BLOCO 3}

\section{TRAJETÓRIA DA CIDADANIA LGBT NO BRASIL}

Neste bloco, gostaria que falasse um pouco sobre a construção da sua cidadania e da sua participação na cidadania LGBT no Brasil.

- Como foi o processo da sua saída do "armário"?

- Você acredita que há cidadania no Brasil? Para quem?

- Você se percebe cidadã? Como? Desde quando? E de que forma?

- Há alguma conquista que tenha influenciado na sua vida? Qual ou quais?

- Na construção da sua cidadania, quais foram as dificuldades que encontrou?

- E quais acredita que são as dificuldades ou entraves que há para a conquista da cidadania LGBT no Brasil?

- A que atribui essas dificuldades ou entraves? 
- Por que buscar cidadania?

- O que você acha da forma como se organiza o movimento LGBT?

- E da forma como ele atua? E persegue as conquistas?

- O que precisa ainda para que LGBT fossem cidadãos plenos?

- O que faria você se sentir com cidadania plena?

- Na sua opinião, o que faz os ativistas acreditarem que é necessário lei para se ter cidadania? E você o que pensa sobre isso?

- O que você pensa sobre o papel do Estado na sua cidadania?

- Você conhece experiências de comunidade que dão sentido há cidadania de um coletivo? Fale-me um pouco sobre isso.

- Como você organizaria a luta pela cidadania LGBT no Brasil?

- Você sente que é dessa forma?

- Você faria diferente? Como?

- Fale-me sobre como é ser mulher no Brasil. E ser lésbica (ou a forma como se identifica)?

- Há diferença na construção da sua cidadania? Fale sobre isso. 


\section{ANEXO 7 \\ FOTOS}

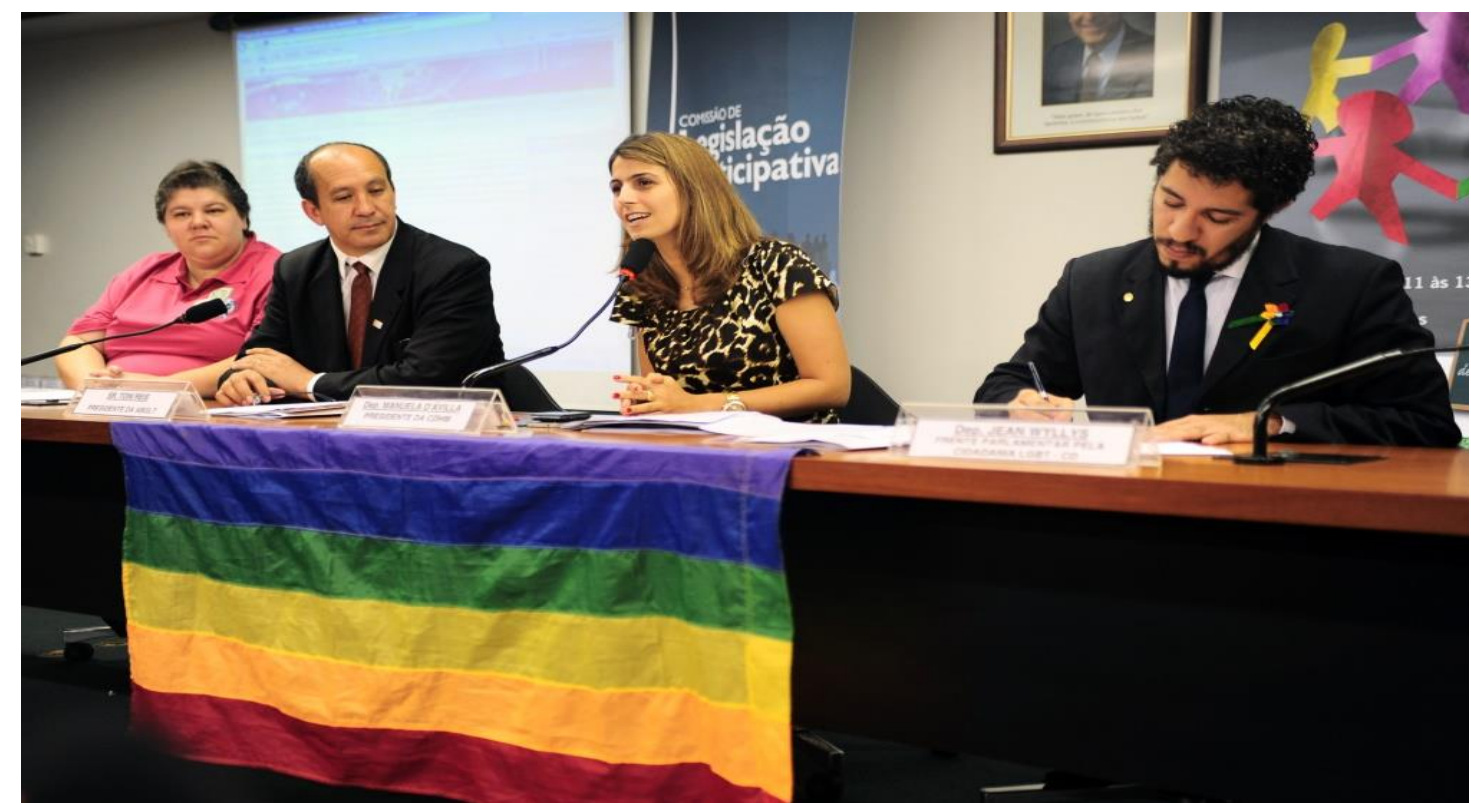

Foto: Seminário: Mobilização Nacional por uma Escola Sem Homofobia, ocorrido em 23 de novembro de 2011, no Plenário 3, Anexo II da Câmara dos Deputados.

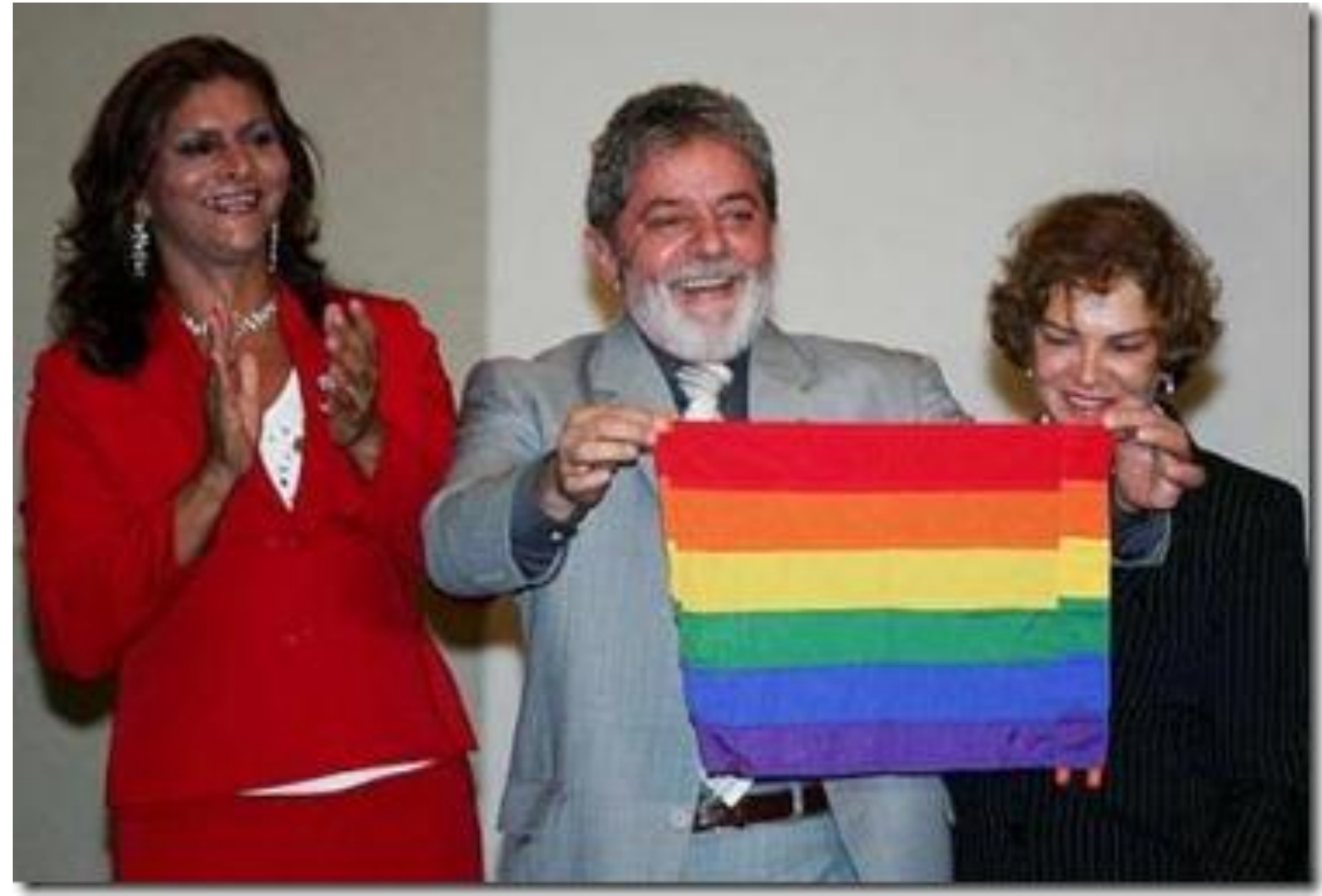

Foto: Abertura da I Conferência Nacional de Políticas e Promoção da LGBT, ocorrido em 5 de junho de 2008, em Brasília. 


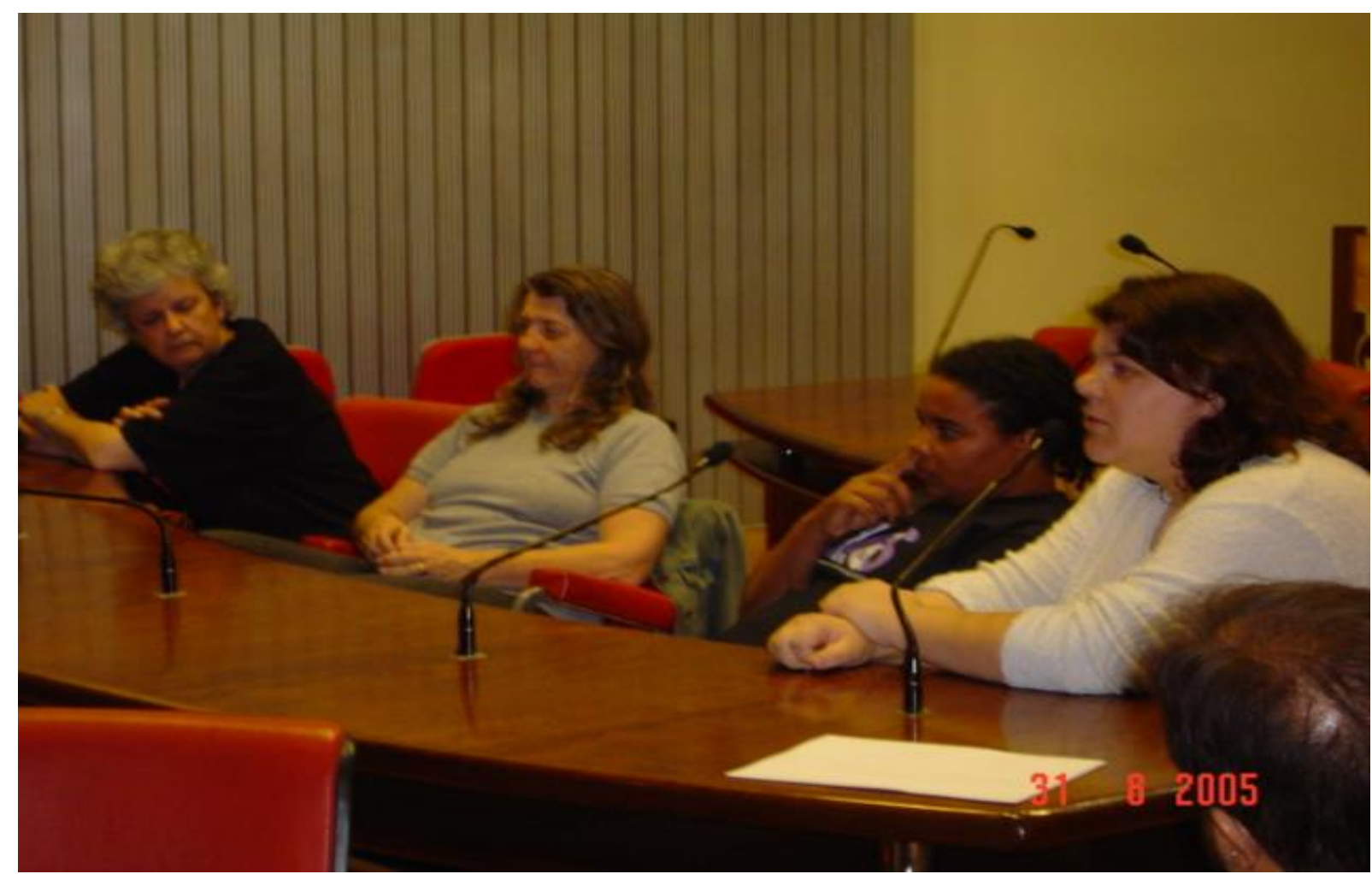

Foto: Debate Mulher, Orientação Sexual, Desejo e Família, ocorrido dia 31 de agosto de 2005, na Assembleia Legislativa de São Paulo.

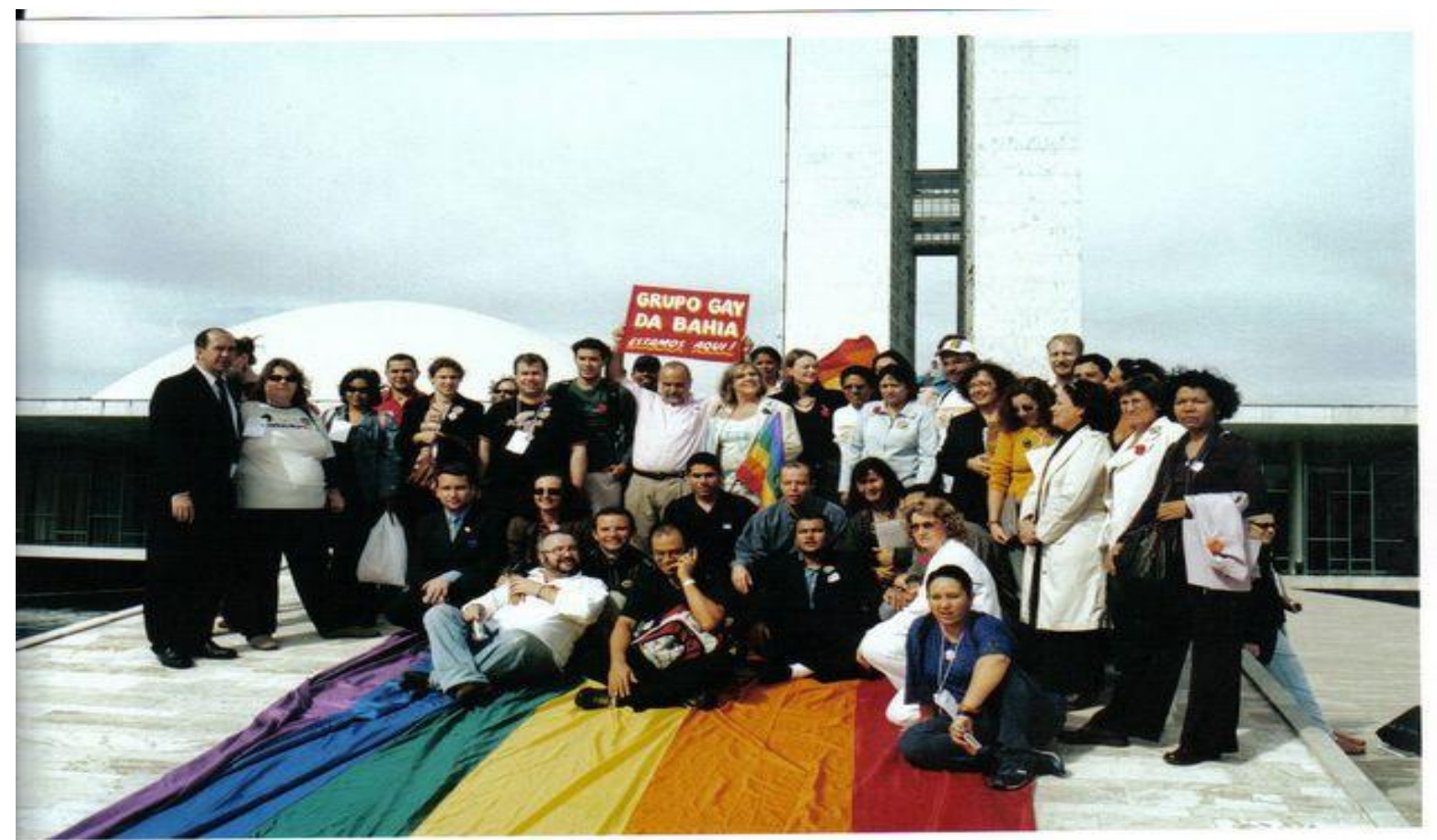

Foto: II Seminário Nacional GLBT, na Câmara dos Deputados, realizado pela Comissão de Legislação participativa em 2005. 


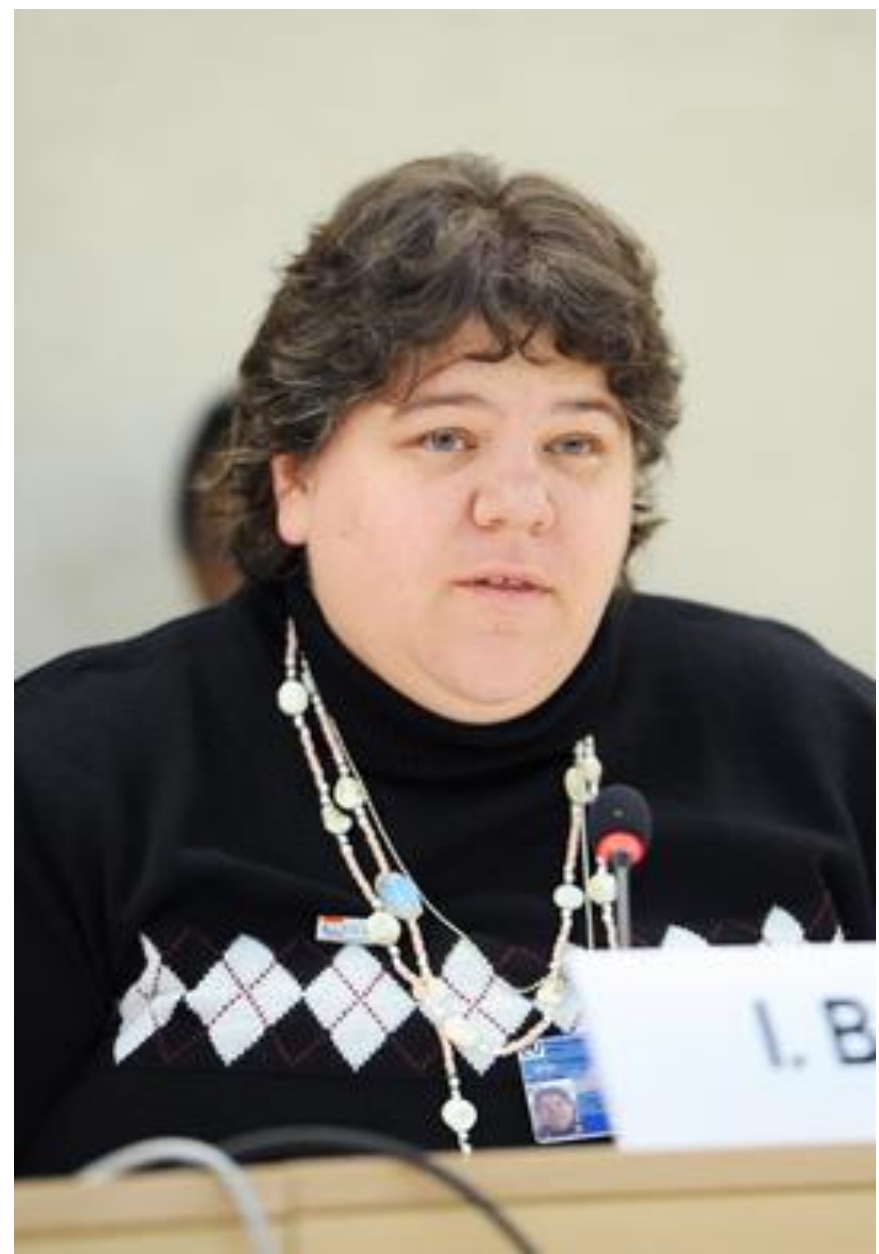

Foto: Representação do Brasil no Painel Discriminação e Violência Baseada em Orientação Sexual durante a $19^{\circ}$ Sessão do Conselho de Direitos Humanos da ONU, em 7 de março de 2012.

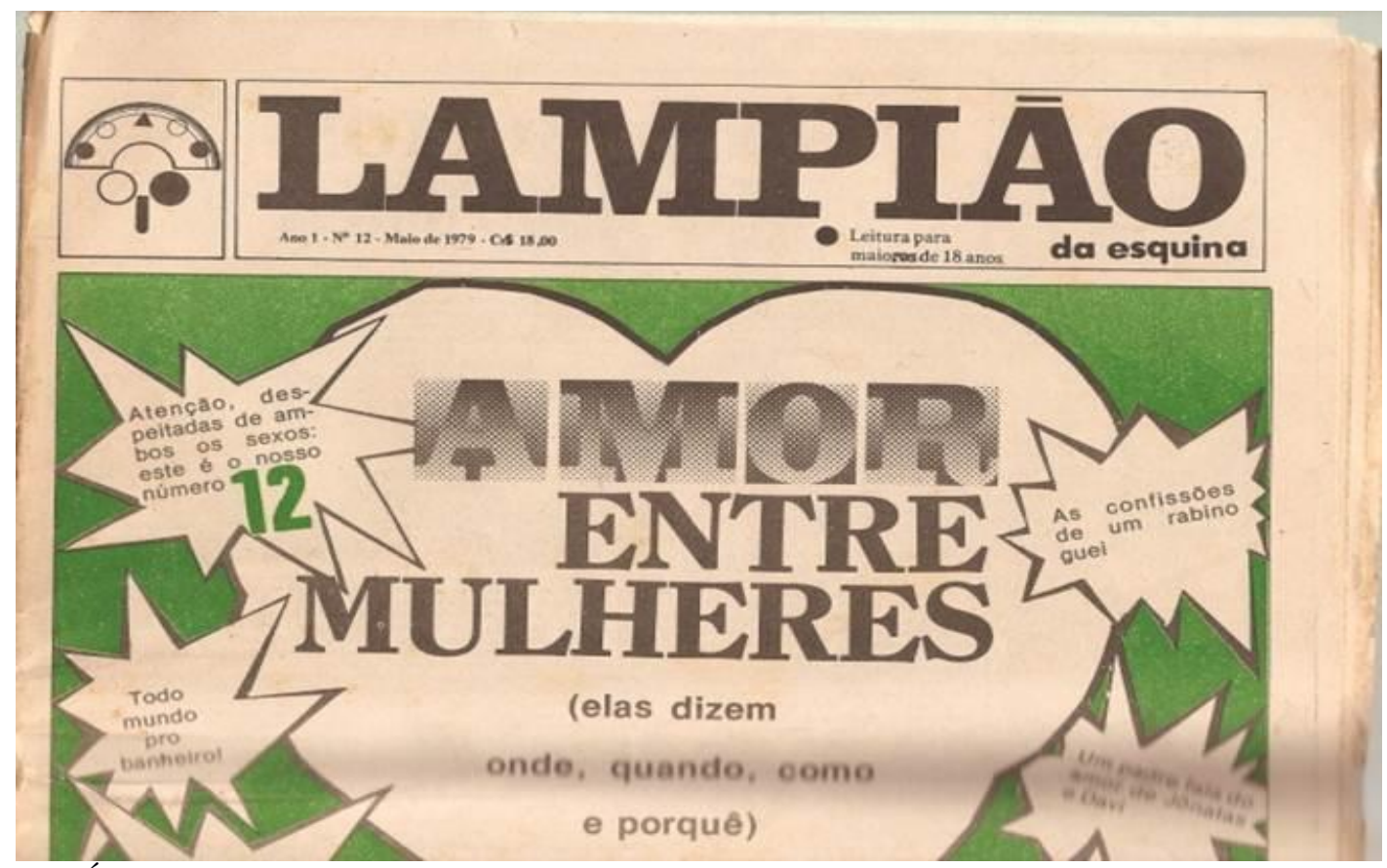

Primeira e Única Capa do Jornal Lampião da Esquina, em maio de 1979, retratando o amor entre mulheres. 


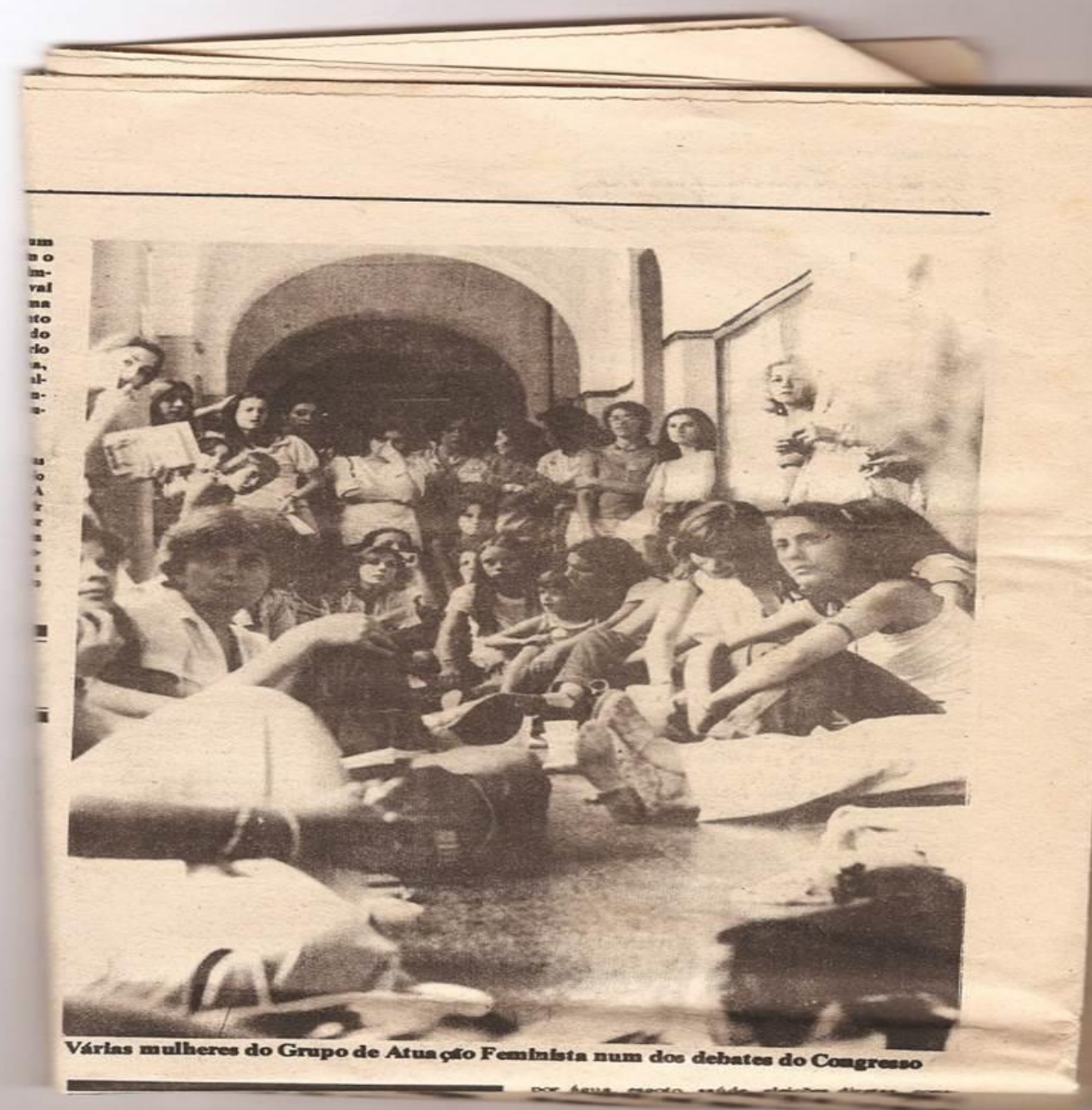

Foto: Participação das lésbicas do Galf no II Congresso da Mulher Paulista, em março de 1980.

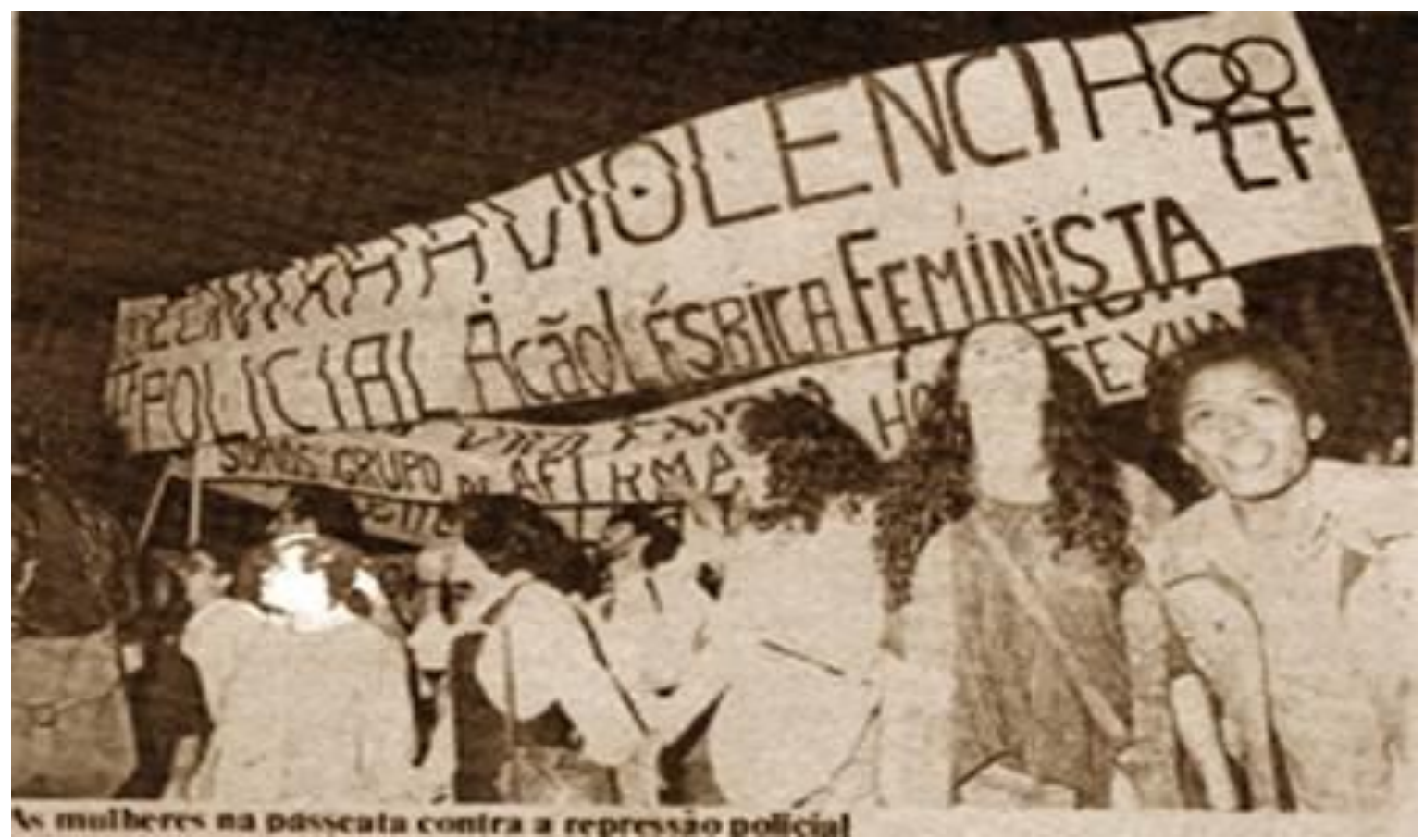

Foto: Ato Público de Protesto Contra o Delegado Richetti, em 13 de junho de 1980. 


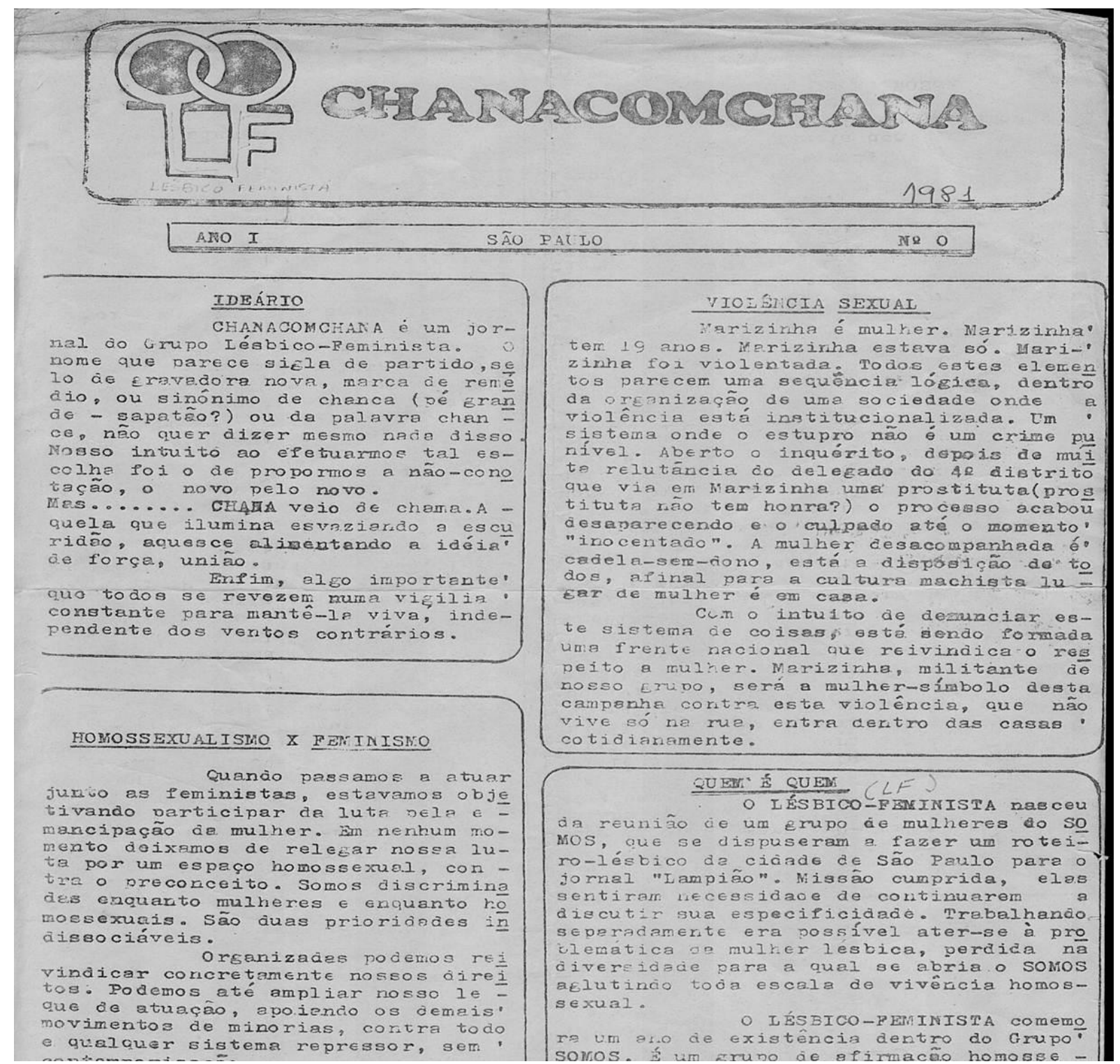

Capa da primeira edição do jornal ChanacomChana número 0, editado pelo LF em 1981. 


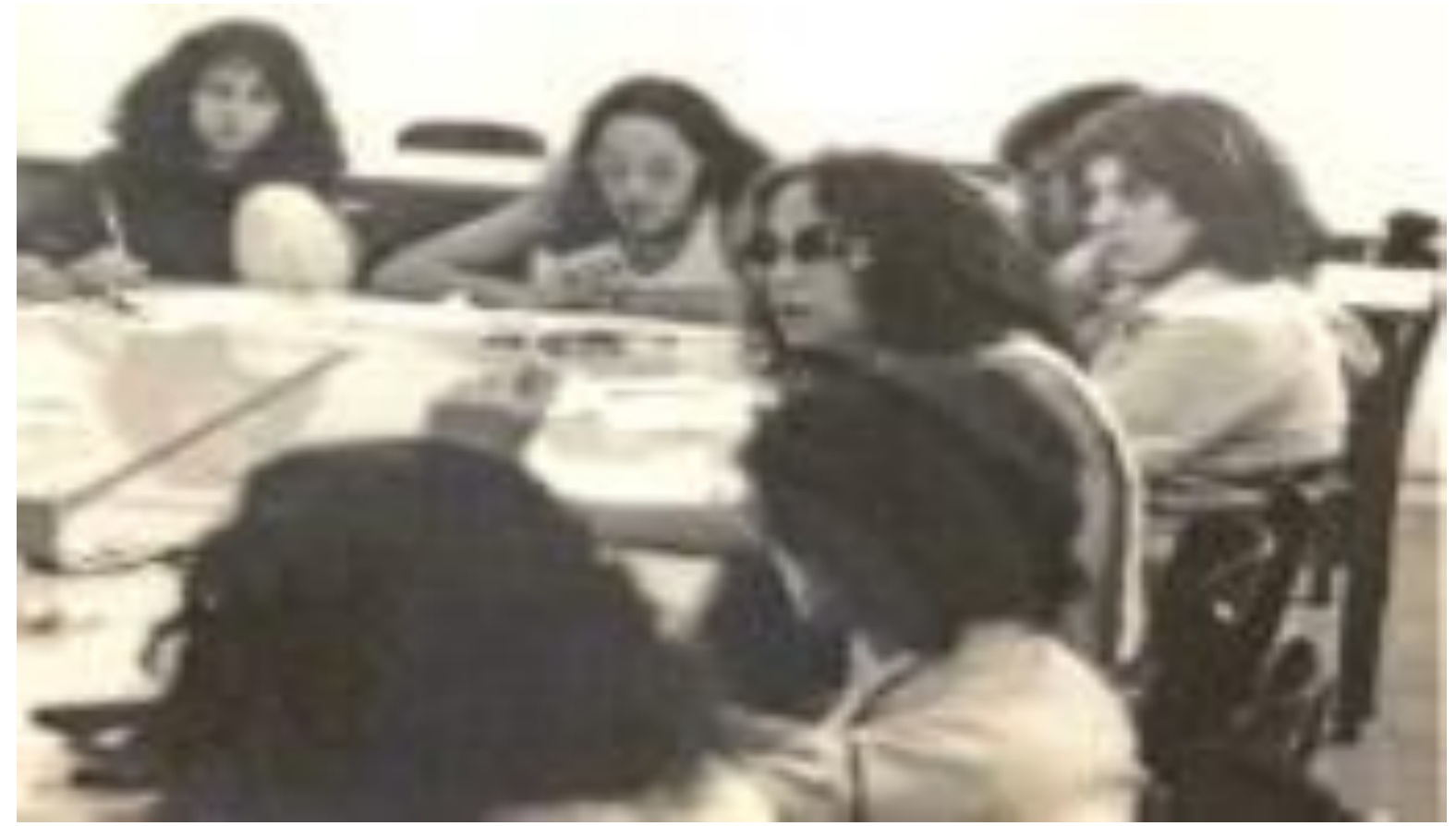

Foto: Primeiro Encontro de Ativistas Lésbicas do Brasil - I Encontro Paulista dos Grupos Homossexuais Organizados, dias 25 e 26 de abril de 1981, Faculdade de Ciências Sociais/USP. Grupos Lésbico-Feminista, Terra Maria, Opção Lésbica (uma divergência do próprio LF, surgido em outubro de 1980), Coletivo Alegria, Alegria, Somos-SP e Facção da Convergência Socialista.

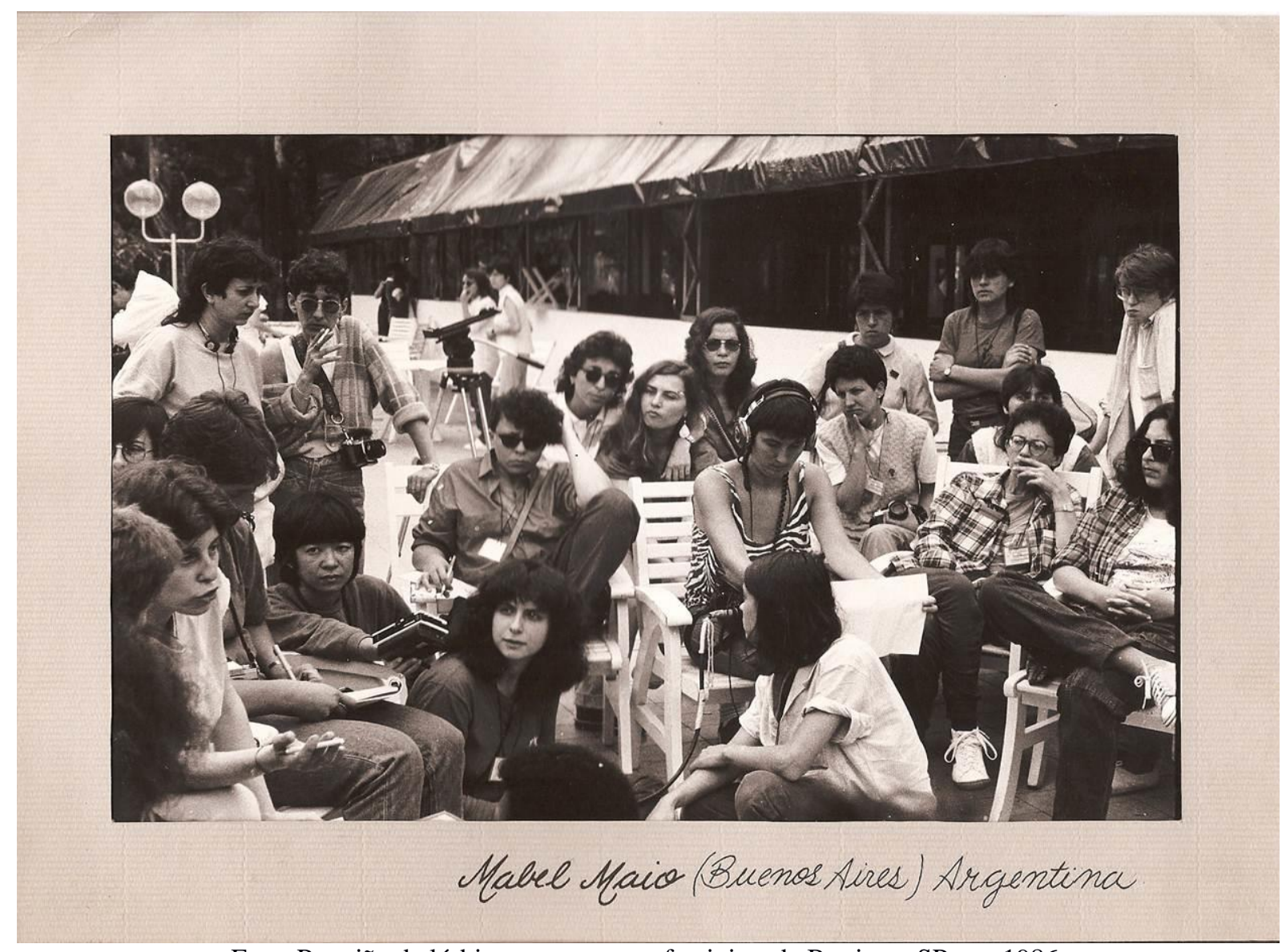

Foto: Reunião de lésbicas no encontro feminista de Bertioga, SP, em 1986. 


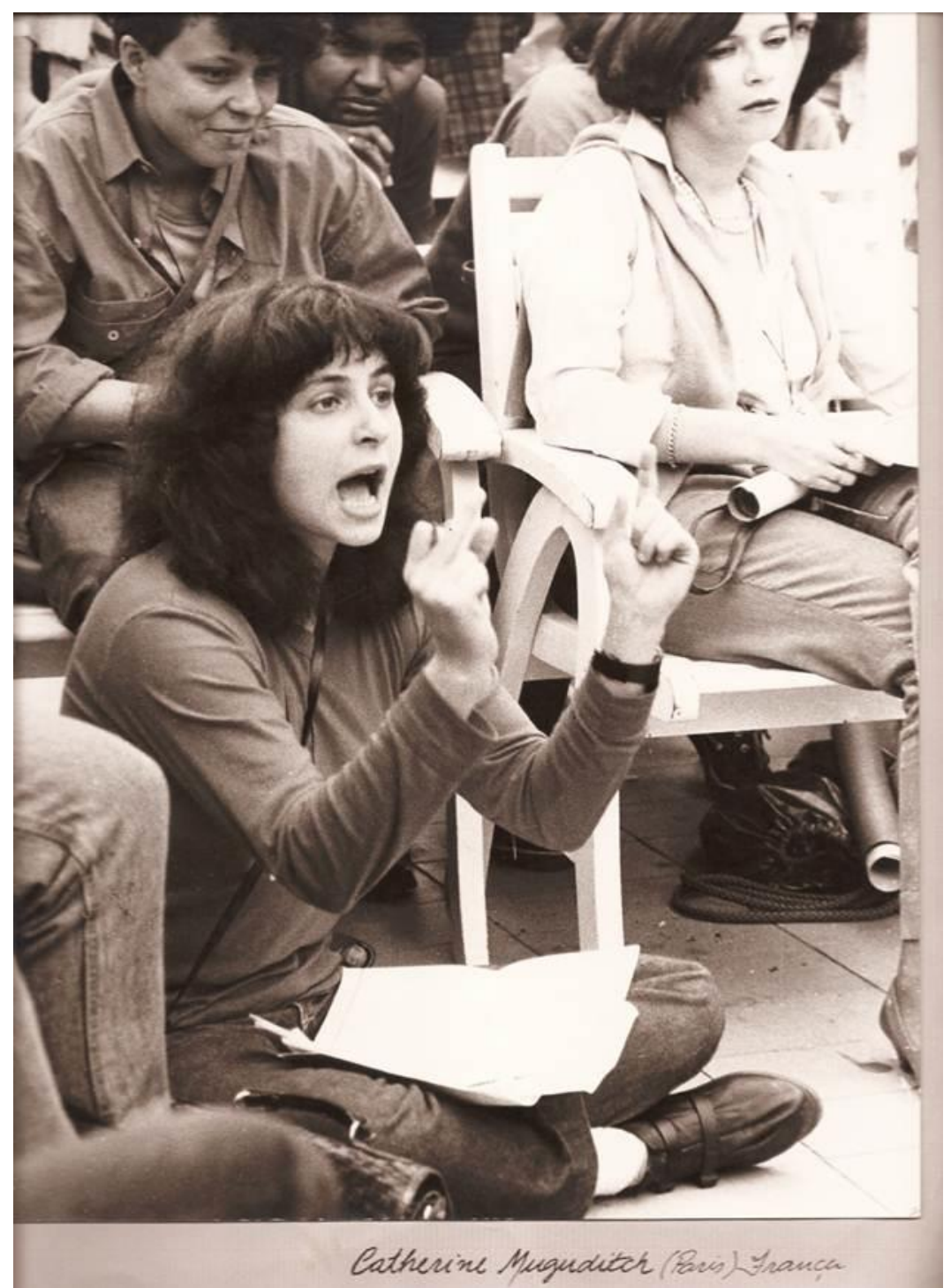

Foto: Rosely Roth, Encontro Feminista Latino Americano e do Caribe, Bertioga, São Paulo, em 1986. 


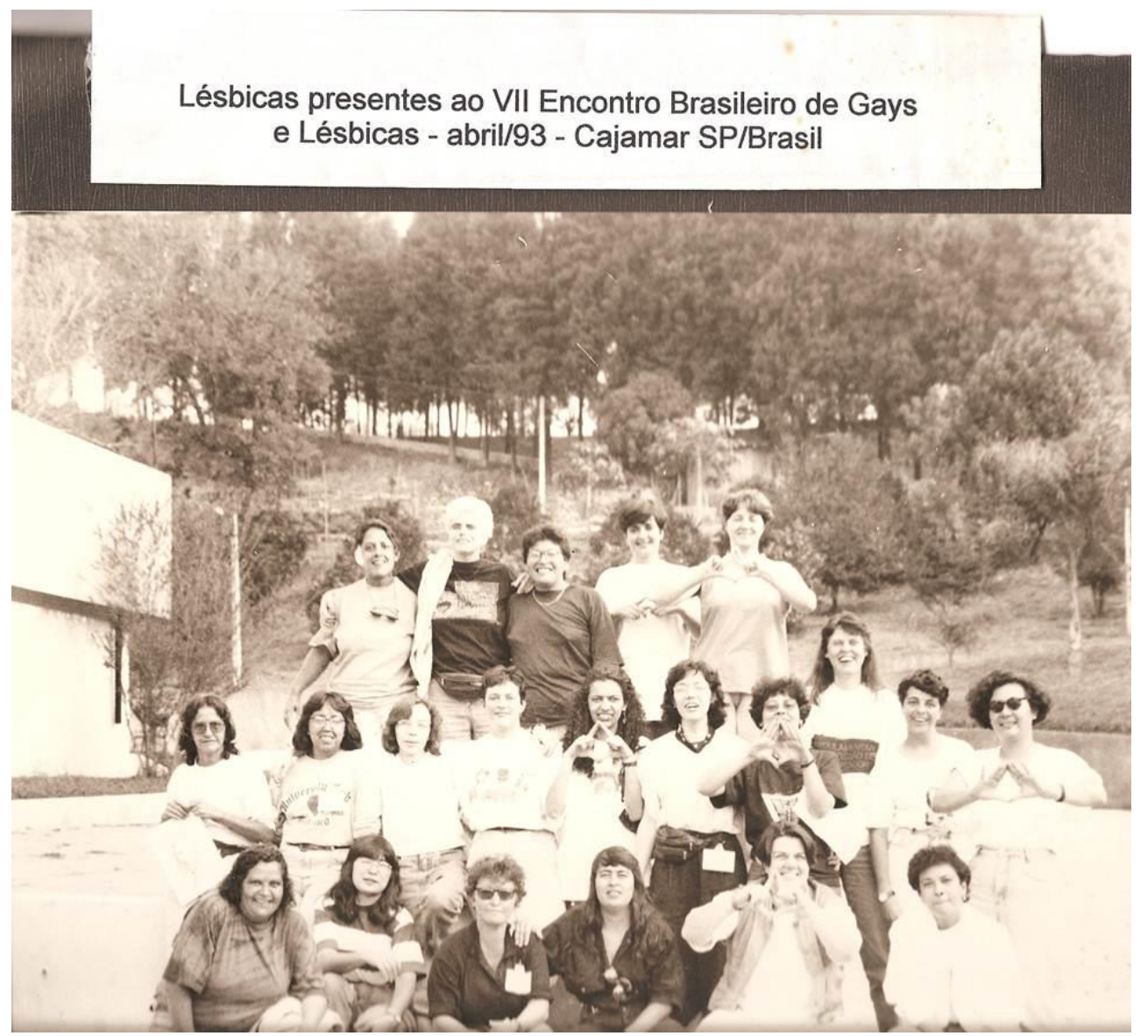

Foto: Ocupação conhecido como organizada por de 1983.

$$
19-08-1983
$$

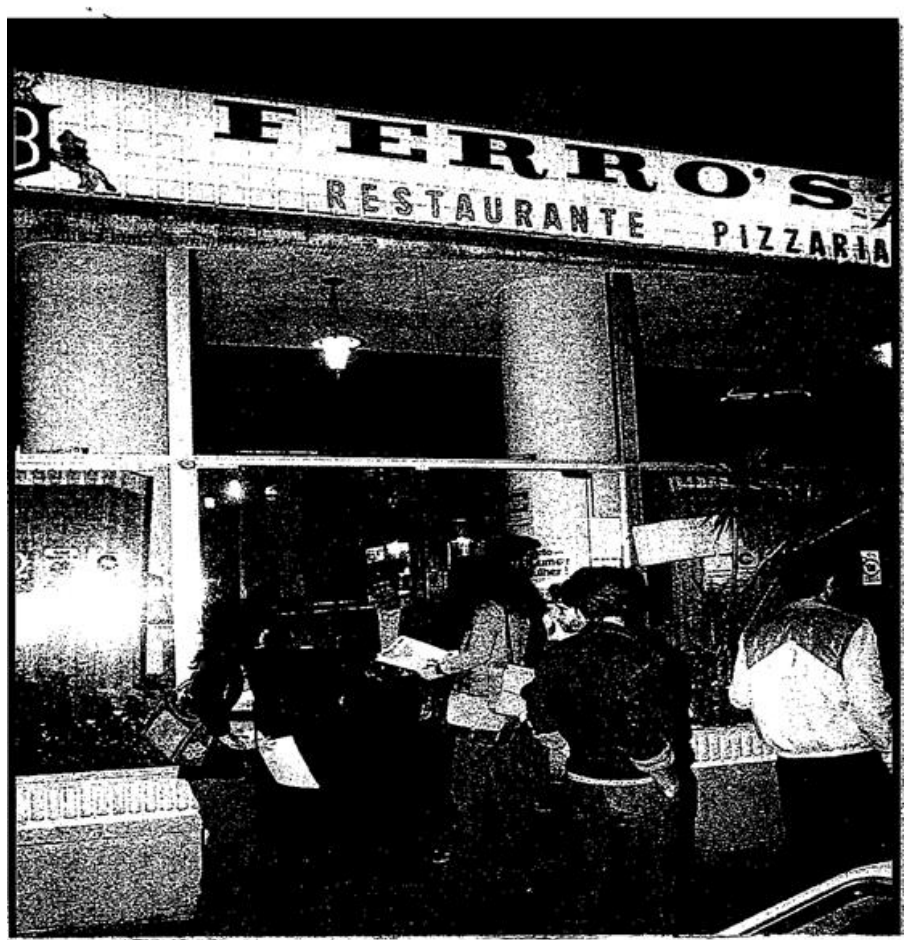

do Ferro's Bar, que ficou Stonewall brasileira, lésbicas em 19 de agosto 


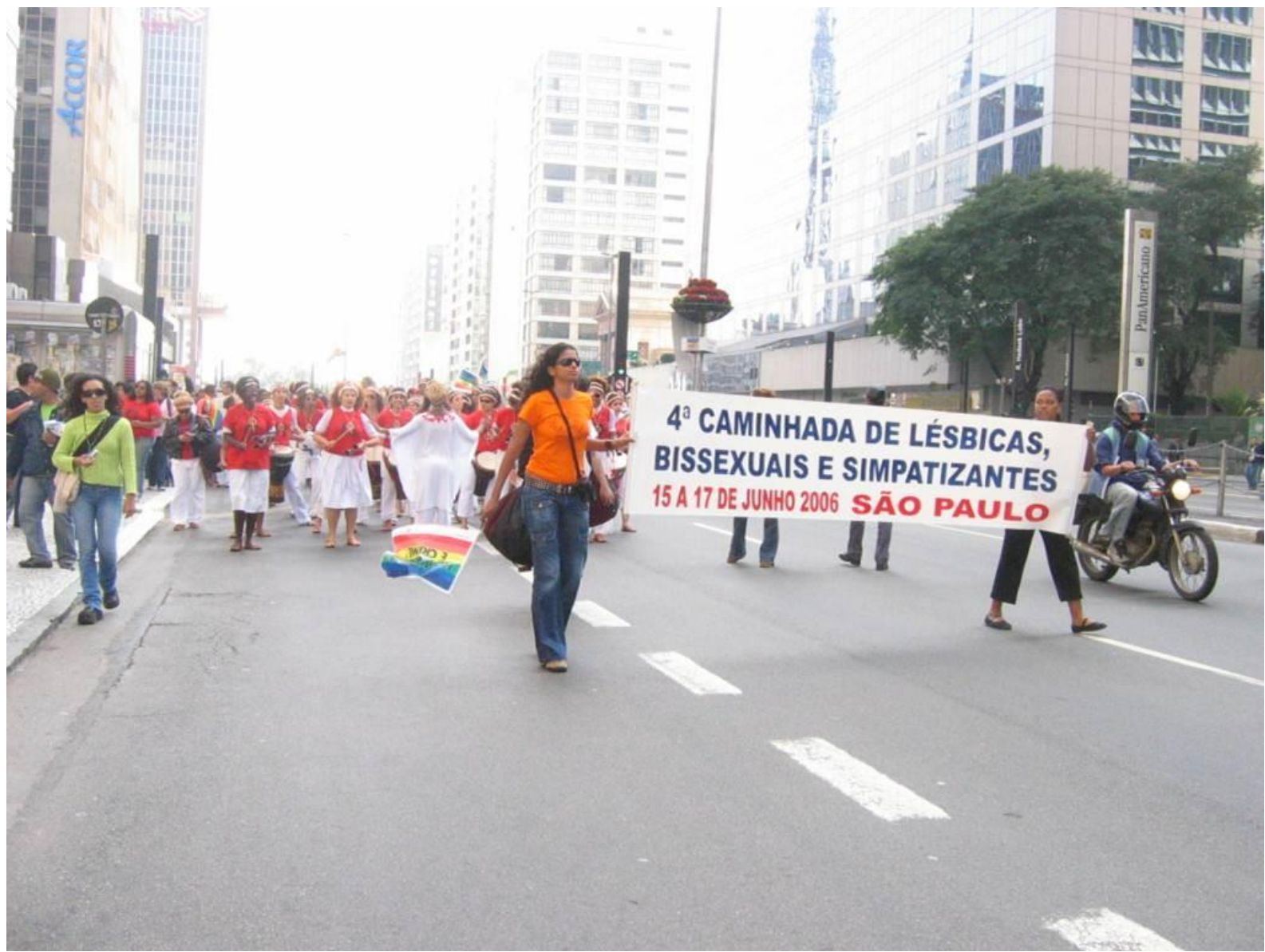

Foto: Abertura da $4^{\mathrm{a}}$ Caminhada de Lésbicas, Bissexuais e Simpatizantes, em 2006, São Paulo, com a abertura do cortejo do grupo de mulheres Ilú Obá de Min. 